.

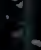

$$
\text { wastes }
$$




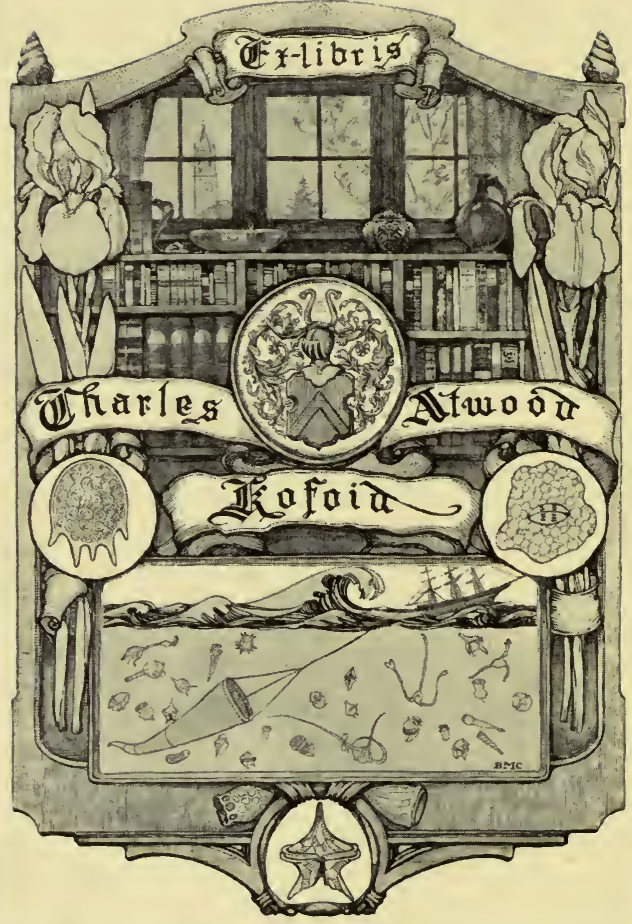




$$
2^{0}
$$

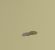

1

1 



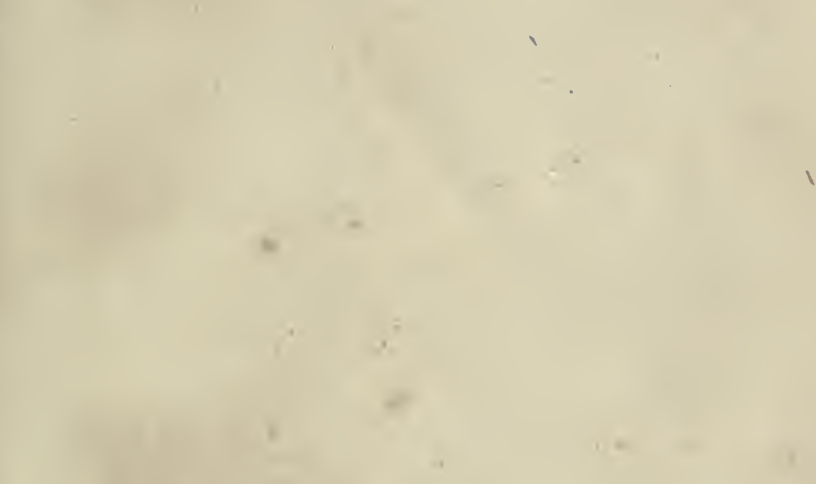

ㄷ․

- $12+2$

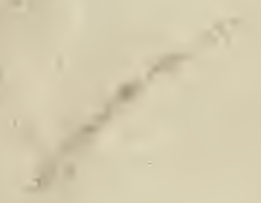

r

4

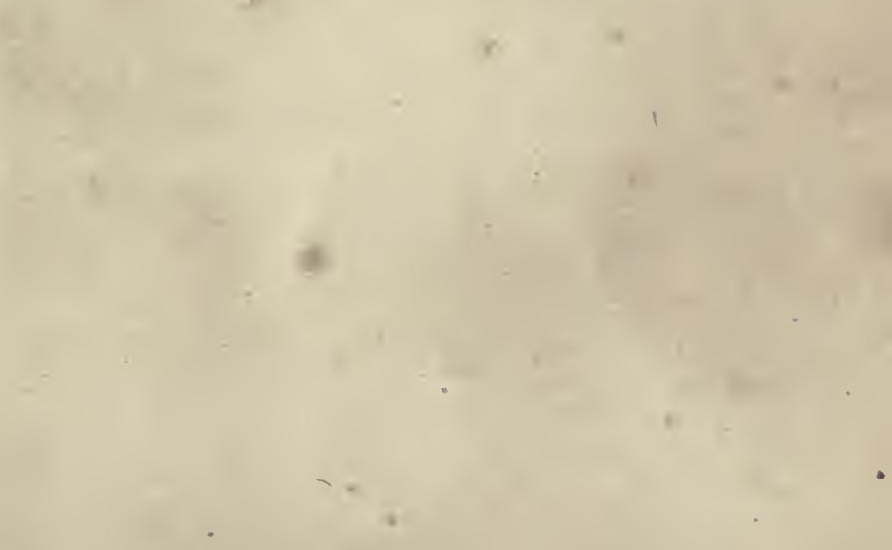






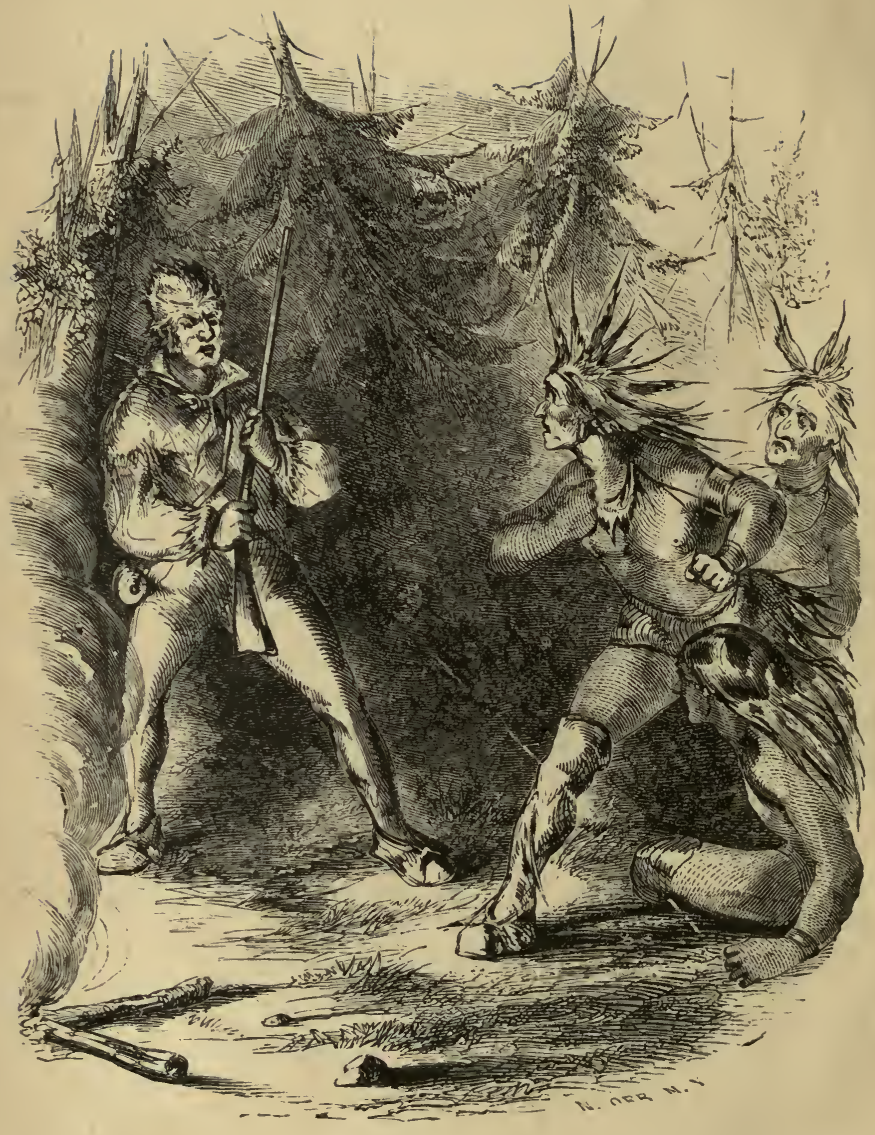

UOGS, WOLVES, MURDERERS OF MY KINDRED, DIE LIKE D GS AND WOLYES. Pagn 2n\%. 


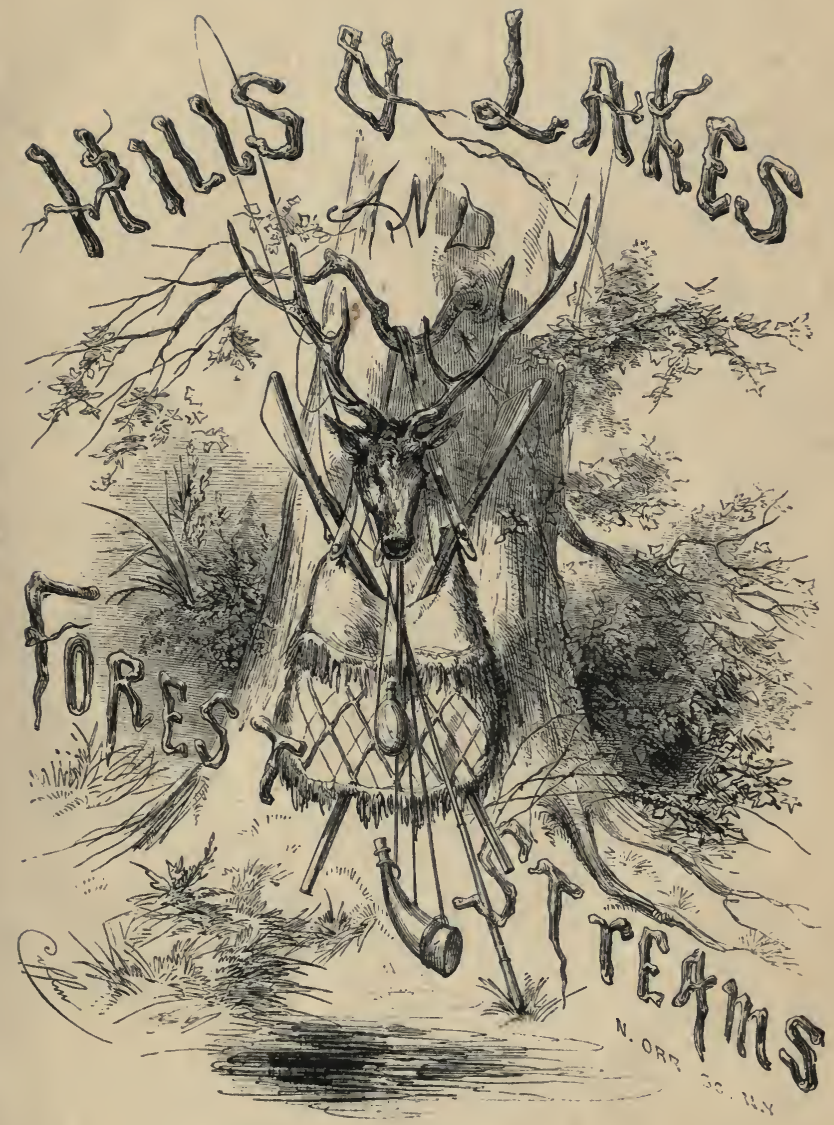




\section{Digitized by the Internet Archive in 2007 with funding from Microsoft Corporation}




\title{
HUNTING ADVENTURES
}

\author{
LN THE \\ NORTHERN WILDS; \\ OR,
}

A TRAMP IN THE CHATEAUGAY WOODS, OVER HIILS. LiAKES, AND FOREST STREAMS.

BY S. H. H

"For myself I prefer the quiet of the country, a ramble along the rivers and brooks; or better still, some wild forest dell, where the birds are merry all the day, and where no unseemly revelry breaks the stillness of night."

NEW YORK :

DERBY \& JACKSON, 119 NASSAU ST., 1859 
Easterkn, according to Act of Congress, in the year 1854, by S. H. H A M M N D,

In the Clerk's (iffice of the District Court for the Northern District of New York.

BT RREOTYPY.- BY

THOMAS B. SMI'I'H,

216 William St. N. Y. 


\section{SKIII $1+28$ 1859}

\section{TO HIS EXCELLENCY,}

\section{HORATIO SEYMOUR.}

B BFora you became a leader of a great political party. ar the chief magistrate of a great State, you loved the woods, the lakes, the deep shadows of the forest and who mountain streams-to throw the fly for the speckled trout in river or brook,

"To follow the stag, o'er the slippery crag, And to chase the bounding roe"-

Permit me, then, respectfuliy to dedicate to you, not as the bighest executive offcer of the Empire State, but as a chivalrous and enthusiastic sportsman, the following work.

TEI A OTBOK.

3 



\section{P R E F A E.}

Ir the reader will lay before him a map of the counties of Clinton, Franklin, St. Lawrence and Essex, and beginning at the Chazy lake, run his eye along thence to Bradley's Lake, then to the Chateaugay, then west to Ragged Lake and Indian Lake, and so down through the series of small lakes, to the St. Regis, and then to the Saranacs, and down along again through three small lakes to the Racquette river, and then down that beautiful watercourse to Tupper's Lake, and to Long Neack, he will note a broad sweep of country, containing millions of acres, which, when the following pages were written, was a perfect wilderness. He can trace out a circle of some two hundred miles in circumference, enclosing natural scenery the most wild and romantic, lakes and rivers the most beautiful imaginable. I was out there several weeks in the woods, along the streams, and floating on those beautiful lakes, and saw during that time no face of a white man, save that of $\mathrm{mv}$ 
guide, or perhaps my own, reflected back from the quiet depths of some of those pure waters, that nestle so quietly among the ancient forests and the hills.

I was on a "tramp," partly for health and partly for pleasure. I had no intention of publishing a book of adventures, but I kept memoranda in pencil in small fieldbooks, and after my return wrote them out as my leisure permitted. Some three or four of the first chapters were published in the shape of letters to editors of my acquaintance. The balance rested until I became connected with the press, as the editor of the Albany State Register. I looked upon the manuscript as a sort of fund, upon which I could draw for light reading, with which to amuse my readers when pressed for "copy." Upon submitting it to one of the proprietors of the paper for his aid in making selections, he surprised me somewhat by saying it was all readable, and advised me to begin at the beginning, without troubling myself by making extracts. I followed his advice, and a large portion of the work was thus published in chapters, in my paper. It was well spoken of by friends, in whose judgment I had confidence, and was somewhat extensively copied by the press. I was advised to publish the whole in a book form. 'I submitted it to a gentleman in the publishing line, and here it is, my first, and very possibly my las ${ }^{+}$effort, at authorship. It 
does not challenge criticism. It makes no special pretensions to literary merit. People who love nature, who have a taste for the old woods, the lakes, and streams, and the forest sports, may read, and possibly be amused by it. They will doubtless find that it contains many faults, if they choose to look for them.

There was, and doubtless still is, plenty of fish, plenty of deer, plenty of sport in that wild region, and, I venture to say, that there is no locality in the United States, at all to be compared with it in natural beauty of scenery. I was over most of the ground again last.fall. The places I visited five years ago, are vastly easier of access now than they were then. The tourist can now go from Port Kent, on Lake Champlain, to the foot of the Lower Saranac, in a day. He will travel the whole distance, save about twelve miles, on a plank road, and the balance on a tolerably smooth common road. All making the most delightful day's journey imaginable.

On the banks of the Lower Saranac, literally at the end of the road, he will find "Martin's House," a new and comfortable country hotel, kept by pleasant, obliging people. Here he will hire a boatman, with his boat and tent, cooking utensils, and a store of provisions, and go a hundred miles, if he chooses, "outside of a fence," over the most beautiful lakes, and along the most delightful rivers 
and streams that the eye ever looked upon, but all wild, remember-all as nature threw them down there, among old primeval things. His journeyings will not be toilsome, he will have no tramping in the woods, save occasional short carrying places, over which his boatman will march with his craft, like a great turtle with his shell on his back. He will see much that I saw, and have attempted to describe, and a good deal that I did not see, perhaps. And if he loves nature, and takes matters easy, and gives himself time, he will come out of the woods, as I did, a stronger, healthier, and a wiser man.

The Author. 


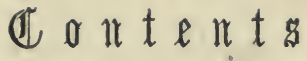

\section{CHAPTER I.}

Ho! FOR THE WILDWOODS!-THE LAAKES AND THE MOUNTANN Streams . . . . . . . . . . . . . 13

\section{CHAPTER II.}

The Prison in the Woods-The Chazy Trout Fishing-HuntING BY TORCHLIGHT . . . . . . . . . . 18

\section{CHAPTER III.}

Ragged Lake-A Fishpond on the Mountarn-The Bark Canoe-A Deer, Chase on the Water . . .

\section{CHAPTER IV.}

Indian Lake-The Ground Cedar and the FawN-The Lake Trout-The Catamaran-The Owls. . . . . . . . $?^{\prime \prime}$

\section{CHAPTER V.}

a Trout-Stream-Partridges-The Fisher-Naming a Lake -A Thunder-STORM in the Forest-Meacham's Lake. . . 49

\section{CHAPTER VI.}

MorntNa IN THE WOODS-MY GUIDE-A FIRST VISTT to the City-a Mistake and its Consequenceg . . . . . 


\section{CHAPTER VII.}

The Deserted Hut-Hunting on the Crust-Forest Justice adMiNistered by a HUNTER-A Captive ANd its Release . 68

\section{CHAPTER VIII.}

Going round the Hudson-The Panther and its CubsFOREST COOKERY . . . . . . . . . . . . 77

CHAPTER IX.

The Lost ChILD-ShacK . . . . . . . . . 87

CHAPTER $\mathrm{X}$.

Dreams-The Pratries on Fire-A Wood-Demon's TorCh .98

\section{CHAPTER XI.}

St. Regis LaKe-The Baid Eagle-His Habits-A PrIZE . 106

\section{CHAPTER XII.}

The Law of the Woods-Big Clear Pond-A Chase aftek

a Deer-A Moose Path . . . . . . . . . . 117

\section{CHAPTER XIII.}

The Upper Saranac-A Song on the Water-A Woodman 8 Notion of the Past, the Present, and the Future, of AMERICA . . . . . . . . . . . . . . . 126

\section{CHAPTER XIV.}

a Sporting Excursion-A Forest Chase-The Music of the Hounds-The Man who Killed the Panther and the Big BUCK . . . . . . . . . . . . . . 136

\section{CHAPTER XV.}

TOJgh YARNS-A Shelter IN a STORM-AN Astonished Bear -AN UNINVITED GUEST, AND HIS UNOEREMONIOUS EXPULSION . 146 


\section{CHAPTER XVI.}

Signs of RaIN-The Tree Frog-A RaINy Day in the Forest ${ }^{\text {Paag }} 153$

\section{CHAPTER XVII.}

a Rainy Morning-Clearing op a New Country-A HalfBREED AND HIS FAMILY . . . . . . . . . . . 163

\section{CHAPTER XVIII.}

STONEY BROOK-AMPERSAND CREeK-Trout-RACKET RIVER-

A Flying Shot at a Buck . . . . . . . . . . 172

\section{CHAPTER XIX.}

A WoOdman's Sermon-His ReLigion of NatURE-His ARguMENT AGAINST INFIDELITY . . . . . . . . . . 189

\section{CHAPTER XX.}

The Silent Energy of Nature-Her Workshops-Her JourNEYMEN . . . . . . . . . . . . . 202

\section{CHAPTER XXI.}

The Eagle and his Prey-The Loon-His Habits-The Partridge-The Squirrel aNd the Forest Mice . . • . 209

\section{CHAPTER XXII.}

The Gray OWL-The Wild Birds-The Dumb Antmal wiser in his Instincts, than MaN in his Reason-The Folly OF CRIMe . . . . . . . . . . . . . . 219

\section{CHAPTER XXIII.}

The Jesutt's Journal-Wild Bulls and Cows, with ANtlers hike the Stag-The "Taming" of the Indians . • . . 228

\section{CHAPTER XXIV.}

a Wind Cat-Long Neak-Round Lake-The Lower Saranao - a Fight between a Panther and a Bear . : . . 236 


\section{CHAPTER XXV.}

The Growth of America-Its Past, Present, AND Future-

A WoOdMan's IDEA OF ExPansion . . . . . . . 246

\section{CHAPTER XXVI.}

MANTFest Destiny-Young AMrRioa on the Move • . . 258

\section{CHAPTER XXVII.}

The Lower Saranac-The Batd Eagle-Umbrella Island-

BaLl-Face MountalN-Mount MaroY . . . . . 270

\section{CHAPTER XXVIII.}

The Story of Otd Pete Meigs-The Massacre, and the RETRIBUTION THAT FOLLOWED . . . . . . . . 286

\section{CHAPTER XXIX.}

A Deerlick-The Vermonter and his LickLoG-Shooting the wrong antmal . . . . . . . . . $300^{\circ}$

\section{CHAPTER XXX.}

Old Shadrach, aNd the Water Rattlegnake-TUCKer's NOtion of Stuavery-The End of that Institution at LAST • 308

\section{CHAPTER XXXI.}

MOONLIGHT ON THE WATER-A VILLAGE WIPÉD OUT-THE AU SABLI-KEESEVIILE-THE GORGE-AN ORE PIT • . . . 324 


\section{I.}

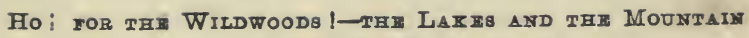
STREAMs.

\section{READER-}

Have you ever been away in the wild woods, beyond the range of civilization, where the sound of the hammer, the lowing of flocks and herds, the voice of the ploughman, as he cries "Gee up! Gee whoa!" to his weary team, were never heard? Have you ever stood on the margin of some beautiful lake, as it lay slumbering in the midst of nature's wild luxuriance, above which the mountains reared their gigantic heads to the clouds, and around which the tall trees stood as "God and nature" made them, unscarred by the woodman's axe, sighing and moaning in the summer winds that swept among them? Have you all alone, by yourself or with an experienced woodman, 
in a little craft hewn from the solid trunk of some gigantic pine, explored its little bays, its secluded inlets canopied by the wide-spreading arms of the trees, and festooned by the wild vines hanging gracefully from the branches above you? Have you listened to the voice of the tiny wave, as it broke in rupples on the white sand at your feet, or the song of the little brook, as it danced over the rocks, to mingle with the pure waters before you? Have you heard, of a moonlight night, as you floated on its silvery bosom, the song of the whip-poor-will, the solemn hooting of the owl, the deep bass of the frog, the shrill cry of the loon, the call of the wood duck, and the thousand other mysterious voices that come up from wood and lake-all mingling in the wild harmony of nature's nightly forest hymn? If you have not, throw down your book or your pen, close your ponderous ledger, cast away your briefs, give care to the dogs, and turn your back upon the glare and heat of the city, its eternal jostlings and monotonous noises, and fly to the deep shadows of the mountains, the forest dells, and the running brooks-away from clustered houses, beyond the green fields, and $r$ sugh it for a few weeks in the woods, among the tall trees and 
the streams, where the lakes lay sleeping alone in the northern wilds.

In these times of railroads and steamboats, a few hundred miles are as nothing. You rise in the morning in the heart of the Empire State, the centre of a circle containing three millions of people. You sleep at night on the circumference of that circle, on the confines of a broad sweep of country, as yet scarcely explored, known only to the bold hunter, who spends all his seasons save the winter, in the pursuit of the game that dwells only in the depths of the forest. Jump aboard of the cars at Troy for Whitehall. Tarry not a moment at Saratoga; there are people there-searchers after pleasure or pelf. The rich, the gay, the fashionable are there; invalids in pursuit of health, and sharpers in pursuit of plunder, all congregate there. Leave them behind you, and ho! for the wildwoods, the lakes, and the forest streams. Stop not at Whitehall, pleasant though it be; there are people there too. A steamboat will hurry you to Plattsburgh; jump aboard and be off! You will soon be gliding along the beautiful waters of the Champlain. You will see "Old Ti.," the surrender of which, old Ethan Allen, as he, with his Green Moun- 
tain boys came tumbling over the walls, demanded in the "name of the great Jehovah, and the Continental Congress!" You will see the ruins on Crown Point-grim monuments of a vanished age! You will see on your left the mountains of Essex, lifting their bald heads to the clouds. On the right you will see flocks and herds, feeding in green fields that stretch back to the base of the hills, and away off in the distance, the Green Mountains looming up in solemn grandeur, on the summits of which the mists of heaven rests, and along whose sides gigantic shadows chase each other, as the light clouds flit before the sun.

Plattsburgh is classic ground. It was the scene of a notable sea-fight, and of a hard contest on the land. But leave it behind you. Battle-fields are commonplace; you can find them nearer home, where the bones of slaughtered men are.more abundant, and the halo of blood-bought glory is brighter. Leave fighting-men to moralize over the places of the fight, and be off for Dannemora, the prison in the woods. There you will be at the end of the road. There civilization has made a pause. Tame life will be behind you, while all before you will be forest, wild 


\section{THE WILDWOODS.}

and unbroken, luxuriant and solemn, tall trees and running brooks, quiet lakes and rugged mountains. Old primeval things all, as they were spoken into existence by the roice of God. 


\section{II.}

Thx Prison in the Woods.-Thir Chazy Taodt Fianja.HUNTING BX TOROHLIGHT

I ARRIVED at Dannemora on the 26th of June. My old friend seized upon my'baggage and sent it to his house, and then gave me my choice to follow it or quarrel with him. We had been friends too long to quarrel, so I followed my trunk, and made my headquarters with him. To those who know him, nothing need be said of his kindness and hospitality, his quiet and gentlemanly deportment, his manly sincerity and firmness of character. To those who do not know him, it needs only be said, "he is every inch a man." Some five miles from Dannemora, in the woods, lays Chazy Lake, on the banks of which is a shantee erected for the benefit of the fishermen that visit it. The way to this lake lays along a path through 
woods, that winds up and over a mountain some fifteen hundred feet in elevation.

The morning after my arrival I left Dannemora, and struck into the woods. I procured a guide, who was perfectly familiar with all the wild region which I proposed to visit, who carried a large pack of provisions, and other things necessary for our tramp in the woods. Among the tools regarded as indispensable, were an axe and augur. He carried no gun. For myself my load consisted of a rifle, and my fish. ing apparatus, including basket and rods.

How I love the woods! the deep shadows and the tall trees-the music of the woods too, its thousand voices all tuned to harmony, and all singing of primitive life and happiness. I love the mountain stream as he goes dashing and frisking over the rocks, diving under the logs, whirling away under caverned banks, where the trout sleeps, dancing over the pebbles and spreading abroad quietly, as if asleep in the still places. We arrived at Chazy, after a weary walk of three hours. It is a beautiful sheet of water, five miles in length, by one or more in breadth. Above it, on the south and east, tower lofty mountains covered with gigantic timber, whilo 
on the west and north the old forest stretches away in all its primeval grandeur. It is indented with beautiful bays, in which a boat may float unseen from the broad lake itself. A hundred little streams come dancing and laughing down precipitous ledges, or from little inlets, into which our canoe would glide, while above us the branches of the trees, festooned with wild vines met, like an arbor in a lady's garden-

"We cast our lines in Largo Bay."

Reader, did you ever throw the fly to tempt the silvery denizen of the lake, or river, to his destruction? Have you watched him, as it skimmed like a living insect along the surface, dart from his hiding-place, and rush upon the tempting but deceitful morsel; and have you noticed his astonishment, when he found the hook was in his jaw? Have you watched him, as he bent your slender rod "like a reed shaken by the wind," in his efforts to free himself, and then have you reeled him to your hand, and deposited him in your basket, as the spoil of your good right arm? If you have not, leave the dull, monotonous, every-day things around you, and flee to the Chazy Lake. If you have and love the sport, still tramp over the 
hills, beneath the cool shades of the brave old trees, to the Chazy.

We did not wantonly waste the good things of God. In ten minutes we had secured trout enough for our supper and breakfast, and our consciences would permit us to go no further. We returned to our shantee, and having supped, prepared for a different kind of sport in the evening. The forest abounds with deer, and these animals in the night come to the water to get rid of the insects that torment them, and to feed on the lilies and grasses that grow in the shallow water near the shore. While thus feeding, you may paddle a canoe, with a light in the bow, literally up to them, provided the light is so arranged that you are behind it in the shade. They will stand gazing fearlessly at the light until the canoe, in some instances, fairly touches them. With a small torch of fatwood in the bow of our dug-out, we shoved from the shore about nine o'clock, in pursuit of deer. We moved slowly and silentiy along the margin of the lake, my guide seated at the stern of the canoe, and I crouched in the bow, just behind the light, and shaded from it by broad sheets of bark,-so arranged that the rays would fall on the forward sight of my rifle. We had 
gone but a short distance when I discovered, some eight or ten rods in advance of us, what to me seemed two balls of fire, but which in fact was the reflection of our light from the staring eyeballs of an old buck that had been feeding in the lake. Unmindful of the admonitions of my guide, I leaned over the side of the boat to get a better view of his buckship, when the light fell upon my face. I have been called a goodlooking man, and told that my features were comely, but that buck thought otherwise, for the moment he saw it he bounded away, and went whistling and snorting up the mountain. He had no appreciation of manly beauty!

We passed silently on into a little bay, where the same phenomenon of double lights presented itself. Slowly and silently the boat glided along towards the spot, when a slight deviation from our course showed us a large deer gazing stupidly at our light. We advanced to within some forty feet of where he stood, when the canoe came to a stand, and I fired. The ball went through his brain, and he fell dead. We were now provided with venison, and we returned to our-shantee. Fatigue makes rest pleasant, and we slept soundly on green hemlock boughs that night. 
A smudge protected us from the musquitoes and black flies, and our slumbers were unbroken.

The next day we started for Bradley's pond, a little lake some five miles deeper in the forest, and midway between the Shazee and the Upper Chataugay. On the bank we built a temporary shantee, and I threw my fly for a few minutes-but it was wasteful to take trout as I caught them there, and I desisted. We coasted this little sea before evening. It is perhaps two miles in circumference, but has little that is attractive about it, save that it lays there all alone in the forest, and great trees hem it in on all sides. Its shores are low and marshy, and I cannot recommend it for its beauty. In the evening we prepared a torch, and struck out on the water in pursuit of deer. It is marvellous, the number there were, along the shores of this little lake. It affords, however, abundant pasture for them. Pond-lilies and grasses grow in the shallow water in great profusion. The pond-lily, in these lakes, differs from any I have ever seen elsewhere. It grows up from the bottom, sometimes from a depth of fifteen feet, with a great rough stem like a cabbage-stalk, of the same pithy and fibrous texture, as large as a man's arm, until it reaches the surface, 
and there shoots out a hundred tendrils all round, at the end of each one having a great round leaf. From each of these great stems, the leaves thus arranged, and connected with it by the small tendrils, spread over a surface of four or six feet in diameter. It is upon these large stems that the deer feed. They. manage to loosen them in some way from the bottom, and feed upon them as they float upon the surface. We could hear them stamping in the water,-and the grating sound of their teeth, as they bit into the stems of the pond-lilies. Every few rods, double lights would glisten before us, and strange to say, the stupid beasts would stand until the canoe approached within six feet of them, gazing in apparent amazement at the strange light that was advancing upon them, but when we looked out from the shadow and showed them our faces, Lord! how they would snort and run. We had no occasion for venison, and we did them no harm that night. In the morning we packed up again, and dove deeper into the forest. We struck for the Chaeaugay (called Shatagee) Lakes, and about ten o'clock came to the head of the Upper Lake. This lake is often visited by sportsmen in the summer months, and has as often, almost been described. It is rarely, how- 
ever, that it has been visited in the direction we came. It has usually been approached from the Lower Lake, on the lower portion of which is a settlement. Indeed, I was told that it could not ell be reached fr ,m the Chazy. But my guide knew the woods, and I followed him. I had good sport every mile of the way. We followed the outhet of Bradley's Lake, and crooked enough it was too. But the stream abounds in trout, and I shot a fine deer and two wood-rabbits on the route. 


\section{II.}

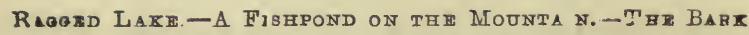
Canot. - A Drer Chast on thit Whthir.

I STARTED the next morning for Ragged Lake, some ten miles deeper in the wilderness. On this expedition we were guided solely by the instinct, or if you please, the judgment of my guide. We found no path-no footsteps or marked trees to point out the way, but through "tangle brush," and over logs felled by the strnng winds, we travelled on. Ten miles in the wilderness, of a hot summer day, with a rifle, fishing-rod, and basket, is a journey which must not be lightly considered; a mile, under such circumstances, requires a multitude of steps and many drops of "the sweat of a man's brow." True, the way is enlivened by the song of the forest bird, the chirp of the squirrel, and the murmuring of the mountain brooks; still the feet become weary, and the mossy 
bank. of some wild stream looks pleasant, as a restingplace from the toil of travel.

Our way at one place lay across a hill, lower to be sure than the mountains on our left, but which rose to an elevation of some eight hundred or a thousand feet above the ravine that wound around its base. Here, on the very summit of a hill, we came to a pond some two hundred yards in circumference, the water of which was beautifully clear and cold; two small streams from its opposite sides started off in contrary directions, on their journey to "the great deep," the one to empty itself into the Chazy, and the other to wander, the Lord knows where, save to its final destination, the mighty St. Lawrence and the ocean. Though blest with two outlets, the pond had no inlet visible to the eye. It was in fact a great spring or reservoir, on a dividing ridge, which received its waters from below, to send them off through the channels I have mentioned. The land around it was marshy, but covered with small boulders, which lay around the edge with the regularity almost of a wall.

Having rigged my pole and line, I stepped from rock to rock to the margin of the pond, and threw my fly. It had scarcely touched the water when it 
was seized by a speckled trout, weighing, perhaps, a quarter of a pound. I caught six more "of the same sort" as fast as I could throw my fly,-and could have caught any quantity; but we needed only enough for a dinner, and I forbore. In the meantime my guide had kindled a fire by the side of a fallen tree, and had already upon the coals a steak, cut from the deer I had killed on the previous night. This together with the trout, subjected to the same broiling process, and bread and butter, constituted our dinner. Iet not your fancy picture mahogany tables, white napkins, silver forks, China dishes, and cushioned chairs,these are far removed from the simple wants and necessities of life-they belong to the cities-to the age of luxury and studied refinement. Clean birch bark, just stripped from the tree, and a jack-knife, are the simple implements of a forest dinner. "Fingers were made before forks," and a hungry man rnust not be over delicate about using them.

I am a temperate man, and can talk right eloquently about the evils of strong drink, but the pocket pistol, from the pack of my guide, loaded with choice brandy, did me no hurt that day, though dis charged at my own head. 
Having dined, and for half an hour rested our weary limbs, we shouldered our traps and marched on : about three o'clock we found ourselves at Ragged Lake,-as beautiful a sheet of water as ever poet sang of, or enthusiast described. On this lake we found no boat; few amateur fishermen have had the courage to visit its seclusion; and the hunter, as he ranges the wilderness, finds no use for a water craft. But my guide was a man of experience, and of vast resource in all that related to wood craft. "We will," said he, "coast this lake as we have done the rest, and that in. a vessel of our own construction."

In the neighborhood of the lake are scattered fir trees of large growth, one of which my guide selected for his purpose, and with his axe felled it to the ground. From the bark stripped from the trunk of this tree, we had, long before sundown, constructed a canoe which, by the exercise of great caution, and by keeping "our chew of tobacco precisely in the middle of the mouth," enabled us to navigate the lake. It was a curiosity in its way,-small saplings or "stadḍles," as my guide termed them, cut first some six feet in length, then being nearly severed in the middle, were bent together like clamps, confined and 
held in contact the ends of the bark; these formed the bow and stern; tow, which had found a place in 'the pack of my guide, was stuffed into the crevices; over this was poured melted gum, gathered from around the knots of the tree we had felled, and from cracks in the unsound trunks of others around us; sticks stretched across from side to side gave it shape, and slim "staddles" laiid lengthwise in the bottom, gave it strength to sustain our weight. Paddles were hewn from slabs, split from the trunk of the tree we had felled. Being all prepared, we launched our homely vessel, and seating ourselves in the bottom on a cushion of boughs, we shoved from the shore.

"She walked the water like a thing of life."

So long as we remained seated on the bottom, it. was steady enough, but when, from our cramped position, it became necessary to change our posture, it required the skill of a rope dancer to preserve our equilibrium, and prevent one's self from being plumped into the cold waters of the lake.

This sheet of water is most appropriately named. Its outlines are peculiarly irregular,--most emphatically ragged. Here a rocky bluff thrusts its long nose 
seaward, while just beyond a wild lagoon winds far ınland, now broad and again growing narrower, until it terminates in a shady cavern, the roof of which is composed of the branches of tall trees lovingly inter twined, forming an arbor of the densest shade, and most refreshing coolness. Here a sandy beảch, shining in the sunlight, along which the little waves ripple, and from which the deer-paths wind away among the willows and alders that skirt it. Here, a sudden and bold descent in the bottom, leaving above it waters of unknown depths, in which the lake-trout makes his home. There a bar stretches far out from the shore, upon which rushes and the tall grasses grow, and further still the brilliant pond-lily glistens in its pure whiteness, like a star resting on the bosom of the waters. To the south-west Mount Lyon rears his tall head to the clouds; standing like a gigantic sentinel overlooking forest and lake, and watching in moveless silence the wilderness around him.

But few sportsmen have ever penetrated to this lake, and its waters swarm with trout. They have never learned to beware of the "fly," nor been taught to distrust the perilous hook. In their simplicity they take feathers and silk for the gadfly, and the miller, 
and the worm, coiled upon your hook, for a genuine wanderer from, the bogs of the marshy bank. "Here they are born, grow great, and die," undisturbed and and unpersecuted by the sportsman.

We found the deer, too, more numerous than we had seen them before. Long ere the night shadows had gathered around us, we saw them stealing out from the thickets that skirted the lake. They would walk stealthily and warily into the water, and after stooping their gracefui necks to drink, would swim away, as if to indulge a cooling bath and saturate their "red coats" with water, and then return to feed quietly by the shore, secure alike from the annoyance of insects and the heat of a summer sun. In the right, we went out among them with a light in the bow of our canoe, and the number we frightened "into fits" was not small. From their actions, I infer that our features were by no means pleasant to theru, for the moment they caught sight of our faces, they ran off with a speed that a race-horse might envy. Our visit will long be remembered by them. The story will go down "to their children, and their children's children," as the epoch of the advent of strange monsters, who came among them in the night to 
frighten their fathers from their propriety, but to our credit it will be told, that we left them unharmed, save by the terrors of our transient presence. We returned to our shantee, and fell asleep under the lullaby of nature's midnight serenade.

The next day we coasted the lake, to explore its hundred quiet and secluded nooks. We found that in the little bays, at the heads of which the mountain streams emptied their cold waters, the speckled trout congregated, while in the deep water, off the bold rocky bluffs, the lake-trout most abounded. We dined near the north end of the lake; our table and our seat was a venerable moss-covered boulder, beneath which a cold spring bubbled up, and above which, great maples spread their leafy branches like a canopy over us; protected by a "smudge" from the black fly and musquitoes, we took our siesta, such as weary limbs and a hearty meal can alone give zest to. After luxuriating thus for a couple of hours, we paddled back along the opposite shore, towards our shantee, to spend the night. On crur way we encountered numerous broods of the wood-duck, whose wings were as yet unfledged, but which, under the guardian care of the mother, skimmed away from us, 
and hid themselves among the weeds and willows along the shore.

We "lay to" under the cool shadow of a huge fir tree that leaned out from the rocks, to rest awhile irom our labor, and to enjoy the beauty of the scenery around us. I had just lighted a Havanna, and was giving its "perfume to the breeze," when, from a

- point just ahead of us, we saw a fine deer step into the lake, and after stooping his head to drink, wade forward and strike out, apparently for the opposite shore. It would seem that he preferred swimming across, to a journey around the lake. We waited until he had got so far from the shore that we could cut him off from returning to it, and then put out in chase of him. The lake was entirely calm; not a ripple disturbed its glassy surface, save the long wake in the rear of the deer himself. Hearing the sound of our paddles, he turned his head and discovered us. For a moment he seemed to hesitate as to what course to take; he looked first in one direction, then in another, as if to ascertain the surest point of escape. We were now between him and the shore, and he struck boldly forward. Our vessel was a clumsy as well as a frail one, and we gained on him but slowly, 
-still we did gain on him. When the chase began, he was some thirty rods in advance of us, swimming for dear life towards the nearest point on the opposite shore, some half a mile or more distant.

It was no boy's play to overtake that deer. In the excitement of the race, however, we forgot the labor, and burning heat of the sun,-we took no heed to the big drops of sweat that chased each other down our faces, as we pulled with might and main after him. Yet we had no thought of taking his life,we might easily have done, for my loaded rifle lay in the bottom of our little craft. Our object was a trial of speed, to witness his wild affright, and his desperate efforts to escape our pursuit. Well, we pulled steadily after him; a stern chase is said to be a long chase, but when we were two-thirds of the way across the lake, our canoe was at his tail. Had we been less excited, it would have seemed to us cruel to witness the agony of his fright. He would plunge forward with an effort that would raise him half out of the water, and then settle down again desperately to his work. With a look of horrible wildness, and nostrils distended, he struggled forward. Once we shouted a wild halo! as our canoe touched him, and the poor 
animal, regarding himself as lost, bleated oui in the extremity of his terror. Still he pressed ncisly forward, our canoe in fierce and hot pursuit, v.stil his hoofs touched the bottom, then the chase 'var up; a few desperate leaps brought him to the besn's, and he plunged triumphantly into his native wills. We heard his long bounds, and the crashing if the dry brush growing fainter and fainter, until the $y$ were lost in the distance, and all was still again. That deer will remember us to his dying day, $-\mathrm{n} \cap \mathrm{r}$ shall we soon forget him. There were few dry threads in ous garments when the chase was ended, and they were not wet by the waters of the lake. Our acquaintance, like many that are formed in this life, though brief, was impressive.

"Slowly," but not "sadly," we paddled back to - our brush shantee, and while the sun seemed hanging like a lantern in the tops of the forest trees, we sat down to our supper.

We were too weary that night to disturb the deer, and we retired early to our boughs; we had to renew our smudge every hour to keep off the insects that "revel in human blood." There was little danger of our neglecting this duty, for as the smoke ceased, the 
tiny trumpet of the musquitoe sounded in our ears, and the sting of his puny spear admonished us to replenish the fire.

Few men can sleep late in the forest, especially among those little accustomed to

\section{"A lodge in some vast wilderness."}

The change from the solemn dirge of the night, to the gay joyous song of the morning, - as note after note chimes in, to welcome the rising day, is too exhilarating to allow of the continuance-of slumber.

We were up before the sun the next morning. A plunge in the lake from a point of rocks near ou shantee, dissipated the lassitude that hung upon us and a few throws of the fly provided us a breakfast of trout. 


\section{V .}

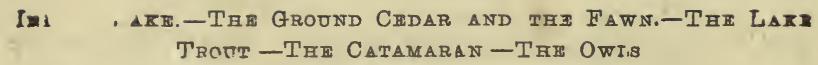

A. ING broken our fast, we took up our line of march for Indian Lake, another beautiful sheet of water, some eight miles deeper in the wilderness. Were $t$ not for the constant change of objects and scener, such a tramp would be anything but pleasant. ? But new sights and new sounds, new birds and new s ings, too, are constantly occurring, so that the exciteraent of novelty robs travel of much of eits weariress. Still it requires some nerve on a hot day, to mexsure miles in the forest, by the repetition of footstr:ps. It is a thing to be considered, and one who sees no charm in a forest life, who hears no music in the wild notes of the birds, and the sighing of the breezes among the leaves of the greenwood, whose ear is deaf to the voice of the running brook, had better 
leave it alone. It will interfere with his comfort. We went trudging along, stumbling over boulders and roots, scrambling over huge logs, and around the tops of fallen trees, for an hour or more, when we came to a patch of table land, slightly elevated above the surrounding country. It was comparatively bare of underbrush, and had upon it but few trees of a larger growth. This opening contained perhaps four or five acres, and was covered with short coarse grass and weeds, with here and there a clump of what my guide termed ground-cedar. This shrub grows from a single stem, as large perhaps as a man's arm, from which branches spread out along upon, or a few inches from, the ground, to a distance of from six to ten feet, so that one of these shrubs will extend over a circle from ten to twen̨ty feet in diameter, presenting an evergreen surface of dense foliage, and at no place over twelve inches from the ground. I was examining one of these, when I discovered two beautifully bright and soft eyes, peering through the intertwined branches at me. I was at first startled, but upon examination found them to belong to a fawn, that had been hid away by its dam beneath the ground-cedar. It was a beautiful little animal, as 
large perhaps as a lamb of a week.old. Its color was a light red, bordering on yellow, dotted with a multitude of dark spots, of the size of a shilling. Its limbs were delicately and beautifully formed, and its whole structure presented an appearance of peculiar lightness and agility. There it lay, snug in its hiding-place, as if unconscious that one of the greatest enemies of its race was gazing upon it. It is a peculiar instinct of the fawn, while yet young, to remain in the hidingplace in which it is placed by its dam, even though danger and death approach it. It did not offer $\mathrm{t}^{-}{ }^{-}$stir, as I lifted it from its bed of leaves, and held it ir my arms, without a struggle on its part, or any attempt at escape. After examining it a few minutes, I placed it quietly in its bed again, and passed on. As we entered the woods, we noticed the white flag of the mother, as she bounded in a circle round us, towards where her little one' had been secreted. She hąd doubtless been watching us as we stood by the spot, and was hastening back to see if her treasure had been stolen.

We reached Indian Lake about noon, and erected uur shantee for the night. Finding no materials for constructing a boat, we proceeded to make a raft, 
which should serve as a substitute. In this we found but little difficulty. On the eastern shore, tall fir trees of all sizes may be found, many of which are dead, or as the woodmen term it, dry. These are exceedingly light and buoyant, and four or five of them, of the diameter of eight or ten inches at the butt, and some twenty-five feet in length, laid side by side in the water, and properly fastened together by crosspieces pinned to them, will easily float the weight of two men. My guide, with his axe and augur, soon succeeded in constructing, such a raft, upon which we fashioned a rude bench at each end, on which to sit. Having provided ourselves with setting poles, we shoved into the lake. Here, as elsewhere, we found no difficulty in supplying ourselves with trout. We poled along the margin of the lake, until in rounding a rocky promontory, we found ourselves suddenly in water too deep for the length of our poles. A breeze, not very strong to be sure, was blowing from the shore, and our raft, under its impulse, put out for the centre of the lake. Having no paddles, and being unable to control our raft, we were forced to see our. selves floating away towards the opposite shore, threeourths of a mile distant Patience was the remedy 
for this involuntary voyage, and as we were in no hurry, having no notes to pay by a given hour, nor railroad station to reach by a given minute, we resigned ourselves to our fate, and floated quietly on. I had a long line, such as is used in trolling, and we rmused ourselves by sounding the depth of the lake. $\mathrm{We}$ found it varying from thirty to some eighty feet. When near the centre of the lake it occurred to me, that perhaps in the deep water, the great trout,- - the aristocratic portion of the finny tribe, might hold their court. Do you remember that in one of Cooper's novels, I can't tell which, the old fisherman of the Otsego discourses about the patriarch of the salmontrout, the old "mossy back," the largest and cunningest trout in all the-lake,- the "Sockdolager," as he called him? Well, I thought of the "Sockdolager," and that it might be, that just beneath me, he of the Indian Lake might be reposing; so I fastened a small trout I had caught near the shore, to the large hook at the end of my trolling-line, and having fastened several bullets to the line by way of sinker, threw out. It had scarcely reached to the depth of sixty feet, when I felt a jerk, which the fisherman knows is not made by any of the "small fry." Hand over hand I 
hauled in, while whatever was at the other end of the line, pulled and jerked in a way that proved him to be anything but willing to approach the surface. Being the stronger, of course I had my way, and in a few moments a trout weighing some six pounds, flopped with a jerk upon our raft. A knock on the head with a stick stilled him, and I had one of the genuine "sockdolagers" of the Indian Lake as my captive.

In the course of an hour we had floated across the lake, and landed on a sandy beach. Here we found numerous tracks of the deer, and the paths, which led away into the forest, indicated that the water was much frequented by them. We followed a small stream that entered the lake, in the hope of finding a spring of cold water. In this we were not disappointed, for a few rods from the shore we found a beautiful fountain, bubbling up from beneath a gnarled and ancient birch. A cup of this, with a sprinkling of old Cogniac, was exceeding comfortable just then.

Our catamaran, though well enough before the wind, was not a thing upon which we could beat up against it, and we had at least two miles of polling to 
get back to our shantee. This we accomplished in as many hours. When we came to the promontory from which we took our forced voyage across the lake, my guide went ashore, and peeling long strips of bark: from the saplings, fastened them together, thus making a towing-line of sufficient length and strength, and fastening one end to the raft, with the other in his hand, he swam round the point of rocks. Having gained terra firma, he hauled in upon the line, and thus towed the raft round the point, myself keeping it off the rocks with my pole. We were weary enough to sleep soundly that night. It must have been past midnight when we were startled from our slumber by a terrific scream which sounded at no great distance from us. My first thought in the bewilderment of the moment, was that the house was on fire, or that robbers had invaded our dwelling. We sat up, with our eyes wide open, staring at each other, when again that terrific scream sounded directly over us, while scream after scream seemed to answer from every direction around us. Andescribable feeling of terror crept over me, and if the truth must be told, my hand was none of the steadiest, as I reached for my rifle. I did reach for it, and, as I grasped it, made 
up my mind to die game. Again sounded that awful scream, and again was it answered from every point of the compass, as if all the demons of the woods were in concert in the horrible din.

"Cuss the owls," said my guide, as he opened his mouth, in a gape like the entrance of a railroad tunnel.

"Who's afraid," said I, as I stretched out again upon my bed of boughs for sleep.

Before the sun rose in the morning, we plunged into the lake for a bath, from the rocky promontory, from which on the previous day, we started on our involuntary cruize across the lake. While performing our ablutions, we noticed a deer, some quarter of a mile or more from us, feeding along the margin of the lake. I took my rifle, stole cautiously to within some twenty rods of him, and resting over a log, fired. He was standing in the edge of the water, directly beneath a rocky bank, three or four feet in height. As my rifle cracked, he leaped at a single bound upon the bank and then back again, some ten feet into the water, dead. The ball had gone through nis.heart, and how he could have made two such des. perate leaps, when thus fatally wounded, was and still is to me, a mystery. 
After having breakfasted, we fashioned a pair of rude oars, and contrived to work them on our cutamaran. We had no disposition to float across the lake again, and perhaps be becalmed half a mile from the shore, for hours. However, the wind rising, we hoisted a sail, by holding a bush erect, with the butt end in an augur hole in one of the logs. This floated us across; and from the opposite shore we started on a coasting voyage round the lake. I sunk my line, in the deep water, and caught another of the large denizens of the lake.

It is a singular fact, that, so far as I could dis. cover, the trout was the only species of fish in this, or Ragged Lake. No sunfish, chub, shiner, perch, or any of the other kinds, so common in the fresh waters of the country. We thought we could designate, however, three different kinds of trout. A small lightish gray one, that seemed to lurk close under the rocks, where the banks were steep and bluff. These had a few specks upon them, of a dingy brown, like freckles on the face of a fair-skinned girl. Near the mouths of the cold brooks, we found the genuine speckled trout in great numbers, congregated there as if to enjoy the coolness of the mountain streams 
Then, in the deep water in the middle of the lake, were the lake trout, varying in size from two to eight, and possibly ten pounds. The ease and readiness with which all these were taken, robbed the fishing somewhat of its romance, for a few minutes would supply us with all we needed, and to destroy more for the mere sport of taking them, seemed like a wanton abuse of the good gifts of God.

Near the south end of the lake is a rocky point, bending round in the shape of a crescent, and forming within the curve a little bay of deep water, containing perhaps a quarter of an acre. At the end of this bay, a stream, not large, but exceedingly cold, empties itself. This little bay literally swarmed with the speckled trout. Standing on a rock a few feet from the shore, I threw my fly. The moment it struck the water, a dozen greedy and hungry fish rose to the surface, and followed in the wake of the one I hooked towards the shore. The least agitation, like the lighting of an insect on the water, would cause them to rush to the spot; a twig thrown upon the surface would collect a school of them where it fell. It was little sport to catch them, but it was a rich thing to know they were there. I amused myself in cheating 
the silly things in the way that was fun to $m e$, while it only subjected them to disappointment. I broke off the hook from one of my flies, and threw for half an hour among them. They got no supper to be sure, but they were very industrious trying for it, and I have no doubt it was a great mystery to them why they did not succeed.

Indian Lake is a circular sheet of water, some five or six miles in circumference. Like all the other lakes in this wilderness, it has many beauties. All around is a dense forest of old primeval trees. On one side, willows and alders skirt the shore, from. which grasses, and rushes, and pond-lilies extend far into the lake, while on the other bold rocky bluffs bound the waters, against which the mimic waves ripple. Occasionally a pebbly beach extends from point to point, while many little bays nestle quietly behind. jutting promontories.

We coasted the lake on our raft that day, and returned to our shantee in the evening. We supped on venison and trout, and laid ourselves away on ous ber of boughs. 


\section{$\nabla$.}

A TrOUT-BTREAM. - PARTRIDGES-OTHE FIBHIR. -NAMING A LAKM-

$\triangle$ THUNDER-BTORM IN THE FORHBT - MIACEAM's LATI.

IN the morning we started south, towards the Saranac Lakes. We left our shantee on the shore, and our catamaran in the water, for any who should come after us. Let no man who loves dry feet, embark on such a water craft. While the sportsman, so far as we are concerned, is welcome to it wherever be may find it, yet we tell him frankly, that unless he builds some addition to it, he will find that, while it carries him safely, it will introduce much moisture to his boots.

We had a long journey before us this day, as ıur design was to reach Meacham's Lake, some sixteen miles in the wilderness. Travelling west on a township line of marked trees for about three miles, we struck a blind kind of path, running south along an- 
other township line, which we followed until after twelve o'clock. Our stock of provisions had run low. Sea biscuit, a little salt pork, some salt, pepper and tea, was all we had left. Of venison we had none, and relying upon our daily forage for our daily food, for the first time found ourselves hungry, without flesh or tish to allay it. We had crossed no stream for miles, and regretted that we had not been more provident of our commissary department, before starting in the morning. However, this we knew, that a country built like the one we were in, must ere long furnish us -with a stream, and we knew, too, that we should find trout, wherever we should find water sufficient for them to swim in. We travelled on, until our ears were gladdened by the sound of a running stream; and a beautiful stream it was too. It came laughing and dancing over rocks, frisking around the trunks of fallen trees, and whirling away under banks, in all the wantonness of unrestrained freedom. I dropped my fly quietly by the roots of a tree that had been undermined and fallen across the stream, when it was in. stantly seized, and a trout weighing near a quarter' of a pound, was tumbling upon the bank. Another and another followed, until enough were caught for 
our dinner. Upon gathering them up, and turning towards the spot where I had left my guide, I saw him with my rifle in his hand, walking around, and looking into the branches of a half-grown hemlock, whistling all the time most furiously. Presently I saw him taking aim at some object in the tree. He fired, and down tumbled a partridge. He fell to loading again, all the time whistling most vociferously. Again he fired, and again a partridge fell from among the branches.

"Halloa! old fellow," said I, "that will do. Fish and fowl will answer for a dinner for hungry men,so leave the rest, if there's more of them there." A fire was soon struck, and in half an hour we sat down to a dinner which, with our appetites, an epicure might well envy.

"Look here, Tucker," said I, while stowing away a leg of partridge, "tell me why you kept up such a confounded whistling, while you were looking for those birds in the tree."

"It was to keep them from flyin' away," he replied. "Off here in the woods, they ain't so shy as they are down in the settlements; and when they take to a tree, so long as you keep up a sharp whis- 
tlin', a partridge will sit still within fifteen feet of you. You may shoot half a dozen from the same tree, pro. vided there's so many there, and you keep on whistlin'."

"That's something new," said I, "and all I've got" to say about it is, that if they're charmed by such music, they have a delicate ear and a singular taste."

There are two things that I advise every sportsman to do, after a hearty meal in the woods, on a hot summer's day. The first is, to smoke a segar or pipe, if he has one; and the other is, to seek some cool shade, and gather a bed of dry leaves, and spreading his handkerchief from the rim of his hat, to keep off the musquitoes and blackfly, lay himself quietly down to sleep for an hour. A longer time will debilitate, and a less time will not rest him. Ten minutes, more or less, will make no great difference; but if called upon to choose either, let him be sure to decide in iavor of more.

Baving dined, and enjoyed our siesta, we travelled on. We diverged from our direct route, to visit a small pond in the south-east corner of the township of Duane. This pond contains perhaps two hundred acres, and was without a name, so far as I know. Its waters are clear, and coider than those of the other 


\section{A Fish Hawk.}

lakes we had visited. A small stream enters from the north-east, about midway of the length of the lake. At the mouth of this stream, the water is deep, and a bay of some four or five rods in width by twenty in length, puts up. At the head of this bay I threw my fly. It was instantly seized by a trout weighing near half a pound. The paths along the banks show that it was a place of resort for game. There were in patches, extending from the shore in many places, grasses and pond-lilies growing in the water; broken fragments of the latter, floating upon the surface, gave evidence that this was a rich pasture for the deer.

As we sat upon the bank, a fish hawk came across the lake, and alighted upon the branch of a dry tree, leaning out from the shore, some forty or fifty rods from us. After pluming himself for a short time, he soared out over the lake, and pausing in mid air, and remaining stationary for nearly half a minute, he dropped suddenly like an arrow upon the water. In a moment he rose, with a fish of apparently a pound or more in weight, in his talons, and with his prey struggling in his grasp, flew away across the lake, and alighted upon a rock, to devour it.

Having rested ourselves, we were about starting 
on our journey, when on the opposite side of the little bay we. saw an animal which though not uncommon in these wild regions, I had not yet seen. It is called the Fisher. Its weight may be that of a fox. Its legs are shorter than those of that animal, while its body and neck are much longer. Its form is like that of the mink. Its color is a dark brown, approaching to black. He was moving cautiously along the margin of the water, stopping, from time to time, to look around him. As he passed behind a large boulder, I raised my rifle, and as he again emerged. into sight, I fired at and killed him. The head of the bay was marshy, and my guide, after divesting himself of his clothes, plunged into the water to swim across. He had not calculated upon its coldness, for as he plunged in, he sighed and blowed like a porpoise. Being a man of nerve, however, he swam over and brought the animal to our side of the bay. The fur of the Fisher is fine and valuable. Its skin is worth from three to five dollars, depending upon the season of the year in which it is taken. We took the gentleman's hide as the spoils of war, and to pay for the trouble of shooting and skinning him. The death of this animal was the occasion of the christen. 
ing of this sheet of water. We hewed a smooth place on the side of an ancient birch, and with a knife carved thereon in large letters, "Fisher's Lake:" Whoever shall hereafter visit it, let him respect the name we gave it and speak of it accordingly.

We arrived at the margin of Meacham's Lake, an hour before sunset, wayworn and weary enough. We found here a shantee, built of poles, and more commodious than the temporary ones we had erected. The roof was covered with bark peeled from the trees the previous year, but the sun had so dried and warped it, that it would afford small shelter from the rain, if a storm should overtake us. From present appearances, such an event was not unlikely to occur during the night. The day had been exceedingly sultry, and a bank of dense dark clouds rested on the western horizon, behind which the sun was fast sinking. My guide soon peeled from the trees around us, bark enough to repair the roof, and procured green boughs for our bed. I found no difficulty in procuring fish. I also shot a brace of partridges, and a small gray good rabbit; so that we were supplied with fish, flesh, and fowl, of the freshest and most delicate kind. About ten o'clock, the bank of clouds from the 
west had overspread the heavens. The lightning be gan to play most vividly, illuminating both forest and lake for an instant, with perfect distinctness, and then leaving all in obscurity, impenetrable as Egyptian darkness. The deep voice of the thunder, growled and rumbled, like an earthquake, in the distance. A low mysterious moaning was heard in the forest around us, such as always precedes a storm, as if the old forest trees were whispering together, of the danger that was approaching. Louder and louder, grew the voice of the thunder. The lightning flashed and played along the surface of the lake, lighting it almost in a continuous blaze. Anon the pattering of the big drops of rain upon the forest leaves, and upon the surface of the water, was heard, and in a few minutes the storm was upon us. The rain poured in torrents; the lightnings flashed around us, while the booming thunders echoed among the mountains. We were securely sheltered, and there was sublimity in the warring elements around us. In an hour the storm moved on. Its roar receded into silence. The stars looked out in their brightness and the night voices were again lifted up, as if rejoicing that the tempest had passed away. .. 


\section{VI.}

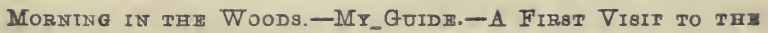
Citr.-A Mistari and its Conserquincris.

- THE morning was the most beautiful that I ever witnessed,-so clear, so cool and bright; and such freshness upon all things. The trees wore a brighter, greener mantle; the little forest flowers, a richer hue. The birds sang more joyously, and even the deep voice of the frog had a note of gaiety in it, that it did not possess before. The lake was perfectly calm, not a ripple disturbed its waters, save where the trout leaped in his gleesomeness above the surface. It was a glorious sight, the rising of the sun that morning; to see him gilding with his beams the tops of the mountains, while in the valley, where that lake lay. sleeping, the grayness of twilight still lingered; to see his light chasing the shadows down the sides of the mountains; to see his rays, resting first on the tops of 
the tall forest trees, and then peering through the opening among the foliage, throwing bright spots upon the surface of the water, and then, as he rose above the brave old trees, giving his beams to wanton on the still bosom of the lake.

My guide had spent some days at this lake, during the last season, and had constructed a canoe, which we found where he had left it, hid away among some bushes that grew near the shore. It required some caulking before being launched, but by six o'clock we had breakfasted, and were on the water. This lake is some six or seven miles in circumference. On the east of it are high mountains, not disposed in ranges, but isolated,-thrown in as it were by handfuls, by the great Creator. On the south, and stretching perhaps for miles, is a valley which many years hence, when the great west shall be filled up, will present beautiful farms, rich in agricultural products, and teeming with tame life. It is wild enough now. The voice of the forest birds, the song of the brook that flows along through its centre, and the sighing of the wind among the trees, are the only sounds that are heard.

We pushed from the beach, and paddled leisurely along the shore, visiting its beautiful bays, and peer. 
ing into its leafy grottoes, where some lovely estuary shot landward among the trees.

My guide was a philosopher in his way, as well as an original. His age was about forty-eight, and his frame was of that robust, hardy, and enduring kind, that is found mostly among the border men of our country. The refinements of society he knew nothing about. He had spent his life in the back settlements, and in the woods. He was a strongminded man by nature, and a thoughtful one. And his solitary ramblings, his forest experience, had made him a reflecting and a wise man in his way.

He had once visited the city, and been followed by the boys, and pronounced green. He took an antipathy to paved streets, the rumbling of carriages, and the impertinence of loafers, and swears be will never go within sight or sound of a city again. He described to me his journey, and his original way of telling his adventures amused me. "I had," said he, "seen all the wonders of the woods; I had tussled with the painters, and taken it rough and tumble with the bears; I had killed the largest catamount, and skinned the biggest buck of the Shatagee. I had slept in the woods for months. I harl hunted the 
moose on snow-shoes in the winter, and been eat up by the black flies and musquitoes in the summer. So, fifteen years ago last June, I thought I'd take a trip to Albany, and dispose of my spelter, and see the sights. I packed up my stuff, and a good lot of it I had too. I had all I could load in a big skiff, of furs and skins, and among 'em was more'n one of the painter and bear. I started from Plattsburgh for Whitehall, and let me tell you, Squire, that's a long road on old Champlain, to travel all alone, pullin' a big skiff, and when you've tried it, you'll believe its some. Well, after four days hard pullin', I landed at Whitehall; there I got my stuff on board of a canalboat, and went ahead. At West Troy I hired a canalhorse and a wagon, and started for Albany. I sold my stuff at a profit; and then I thought I'd take a look at the sights. So I went gaping about, lookin' in at the windows of the stores, and staring at the queer signs, and lookin' at the carriages and the women, in a way that was no doubt uncommon. The koys got round me, and wanted to know where I was caught, and whether my mother knew I was out. I didn't mind this much, for they were too small to get angry with, and they didn't know any better. Pretty 


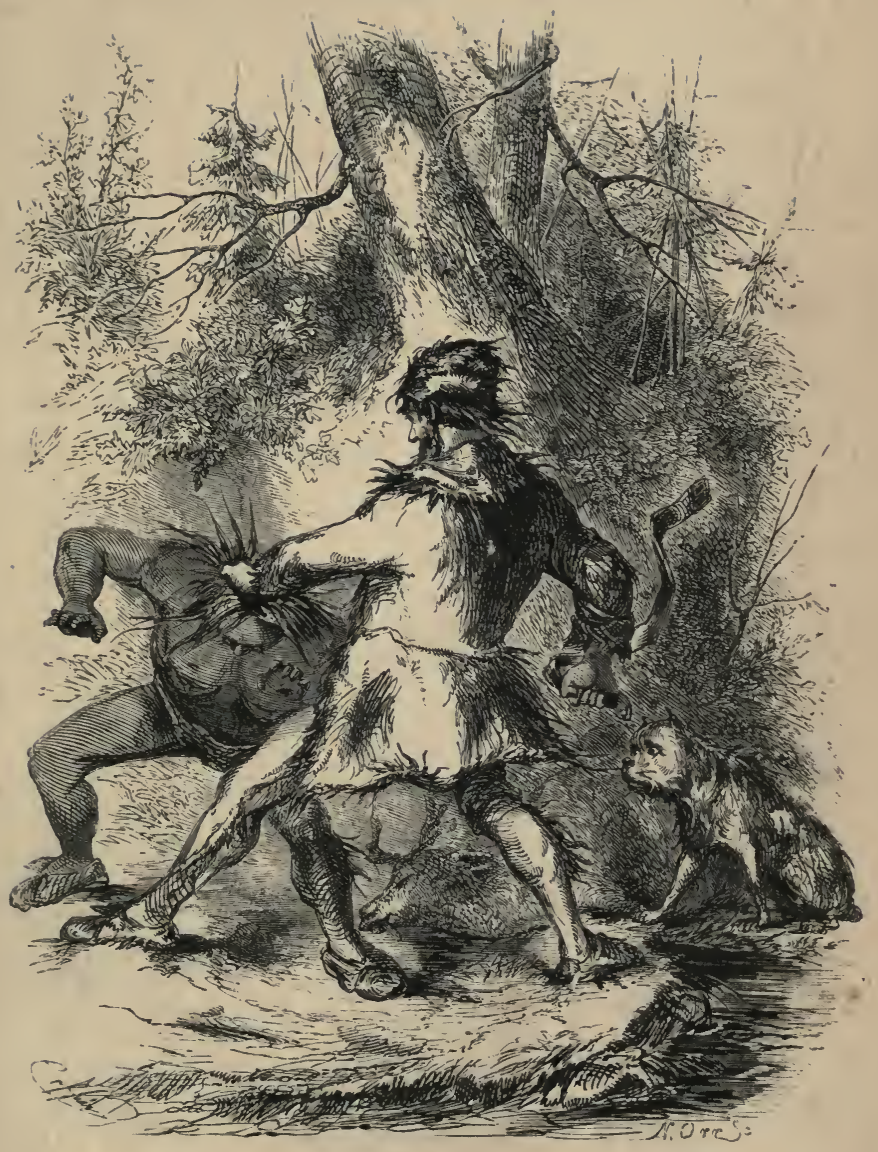

TIE WAY I LATHERED HIM WITI MY LEATHER BELT, W $A$ is A THING TO STAND OUT OF THE WAY OF 



\section{A First Visit to the City.}

soon a full-grown, ill-lookin' young man thought he'd take a hand at the sport, and jin'd in with the boys in poken' fun at me. He pushed the little ones agin me, and wanted to know how many cubs like me, the old bear had at home. I'm a patient man, Squire, but there's some things I can't stand,-and bein' laffed at without occasion, is one of 'em. So I told the young feller, if he'd mind his business, I'd mind mine, and that would make it all straight and right between us; besides, if he didn't, he'd get into a fix that wouldn't be pleasant. The chap seemed to have grit in him, and squared off for a fight, bút what it was to be about, I didn't understand any more'n the man in the moon. I advised him in a good natered way, to keep on his own side of the trail, but it didn't do any good. He seemed to take it for granted I was scared, and that made him more full of fight than ever. He laid his hand on the collar of my old huntin' coat, and at a jerk tore it half off my back. Blood's blood, Squire, and mine was up. I wan't a baby then, and ain't now. That handful of bones" (said he, baring his brawny arm, and doubling his huge fist,) "hain't often been flung at a human critter, and I hope never will be again. But when it lighted on that fellow's 
face, it's my opinion he saw stars. He went over and over, into the middle of the street, and when he went down he laid still. He hadn't any fight left in him. He got on to his feet at last, and staggered like a drunken man. I was sorry I hit him so hard, but it's my opinion he deserved what he got. Presently a man walked up, and said I was wanted. 'Who be you,' said I. 'I'm a constable,' he replied, 'and you must go with me to the Perlice.' 'All right,' said I, 'go ahead; law is law, and must be gin' in to.' Well, we went to the office, and I've a notion, Squire, that Justice of the Peace was an honest man, for he didn't seem to want to take advantage of me because I didn't know the ways of the Court. The feller I struck was there, and sich a face as he carried, was a sight to see. His nose was swelled up like a great sassenger, and his eyes had a long way to look, before they could see outside of the great puff around them. Well, he was called on to swear, and the way he lied agin' me, was a sin to hear. You'd a believed from what he said, that the fault was all on my side, and that he was the innocentest lamb that had ever been worried by a wolf. I thought it all over with me, when the Squire asked me what I had to say. 
“'Squire,' said I, 'I'm a peaceable man, and never had a quarrel with a human critter but twice before, and then I couldn't help it. I never struck a man but once before, and I've been sorry ever since, I was forced to do it. I'm a stranger to the ways of the city, and may be I don't act as genteel as I ought to. I'm a man of the back settlements, and the woods. I'm an honest man, and came down on an honest callin', from the Shatagee country. I meddled with nobody, and have been as civil as I know how to be. That lyin' cuss, was for imposin' on, and abusin' me. He has told a cussed pack of lies, from one eend to the other, exceptin' a single fact, which I own up to, Jecause it's true. I did strike him, and I was sorry that the blow was so hard, but since I've hearn hirk swear, I've a notion I sarved him right.' Then I told him the real truth, in a plain, straight forard way.

"' 'Tucker,' said he, for I told him my name, 'I don't doubt your story myself, for you look and talk like an honest man, but I can't take your statement agin' the oath of the witness.'

"'Squire,' said an honest lookin', blue eyed boy, of about twelve year old, that had followed us into the office, 'that man's story is every word true, for I 
seed it all myself;' and he stepped up to the book and was sworn, and told the whole story, true as gospel. 'The case is dismissed,' said the Squire. I thanked the honest-hearted boy, that didn't like to see a wrong done, and the Squire thanked him too. Well, I harnessed up my old hoss, and started. I pulled up old Champlain for home, and when I set my foot in a city again, 'twill be after this. When I get into the woods I know all about things. I've travelled among 'em, and seen so many wild animals, that I know their natur'. The still lakes, that lay away off here all alone, and the streams that steal along round among the rocks and hills, are like old neighbors; I know them alf, and I love them. I wonder, Squire, that more people don't, like you, come out here into the woods, and see what God made, and as he made it. Why don't they get into the deep forests, among the tall trees, the streams, the lakes and mountains, amouy the cool shades, to hear how cheerfully the birds sing, and what nater' says, when she talks to herself."

The stories of my guide were a source of great amusement to me. He had encountered every variety of adventure in his long experience in the woods; twenty-five years of his life, had been spent among 
the lakes and streams, in this wild country, and it may.well be supposed that he had seen and experienced much, the recital of which, to one unused to such scenes, would afford a vast deal of interest.

"You see," said, he, "Squire, that big rock," pointing to a boulder on the margin of the lake, about the size of a haystack. Against it, were piled large fragments of rocks, and just in the rear of it was a space that would form a comfortable den for a bear or a wolf. "Well," said he, "I had a time of it right there, ten years ago this summer. I'd been out here huntin', and one day I was paddling along by the shore, when what should I see friskin' about on the sand there, just by that rock, but two cubs about as black as the devil, and the size of a big cat. I knew the mother wasn't a great way off, and wouldn't take it kind of me to be medlin' with her babies, but I wanted them young bars, and made up my mind to have 'em too. They didn't seem to be at all afraid, but set up on their bottoms, and looked at me as I stepped ashore, as impudently as though I warnt human. I examined my rifle, and saw 'twas all right, and seizing one in each hand, tossed them into the canoe. They set up a terrible cry for such small 
critters, as I knew they would, and I jumped into the canoe and shoved off. I pulled their ears, and made 'em cry out again. Presently I heard a crackling and crashing among the oushes, and a puffing and growling, and I knew the old she one was coming. I was eight or ten rods from the shore, and as she came in - sight, I held up one of the cubs and made it sing out. The old bar saw me, and her baby, and put into the water after me, for a fight. I let her swim to within about twenty or thirty feet of the canoe, and picked up my rifle to settle matters, and pointed it at her and pulled. The cussed thing snapped. Things began to look serious just then; my best chance was to paddlé for it, and Squire, the way I pulled for a few minutes was great-I gained on the old lady, and had time to prime my rifle. This time there was no mistake. As she came within a few yards of me I put a ball through her skull, and she turned over in the water dead. I hauled her into the canoe, and pulled back for the rock again. I wanted a crack at the father of the family, if he was about. So I waited until towards night. Occasionally I'd make the young ones squall, as a kind of notice to the old one, that he was wanted. Sure enough, just before sundown, in an. 
swer to the cry of the cubs, down came the old he one, angry as anything, and full of fight as a mad dog. I pulled the ears of the little cub, and he cried out again, and in plunged the old fellow after me. I settled him too, with a rifle ball, and then pulled ashore for the night. I knew there were no more bars there, and the cubs and I, slept very well in the nest behind the rocks. I did a good thing that trip; I got nine dollars apiece for the skins, and twenty dollars for the cubs. They were hungry enough, when I got home, but they soon got over it, and were gentle and playful as kittens. I took 'em down to Plattsburgh, and sold 'em to a man from Montreal."

We landed by the rock, and he pointed out to me, the place where he had slept with his cubs. It was a proper place for the lair of bruin, and had we not already a comfortable dwelling, would have made no bad resting place for us. 


\section{II.}

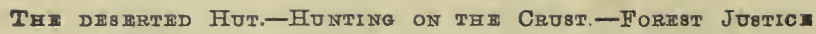
ADMINISTRRID BY A HUNTRR.-A CAPTIVII AND ITS RILIAAR.

From the top of this rock, we had a view of the whole lake-a small pocket telescope brought everything close to me. We saw several deer, feeding along the margin, in different directions, and some half a mile down the lake, we saw one swimming across to the opposite shore. We saw numerous broods of wild ducks, sporting in the water, now diving and again skimming along the surface, in play. ful gyrations round the careful mother. As we were watching one of these broods, in a little bay some fifteen rods from us, we saw them at a signal, which we heard from the mother, dart suddenly from sight, among the flags and rushes, while she, too, hastened to conceal herself. We saw the cause of this alarm, in a large bald eagle, that came soaring majesicically 
over the lake. This king of birds makes prey of the waterfowl, and here in the solitudes of the wilderness, he is the only enemy they have to encounter. The price of their security, is unsleeping vigilance, and were one of these broods to leave the shelter of the shore, the chances of their return would be none of the surest. We passed into a little bay, that shot round and hid, as it were, behind a rocky point, to prepare dinner. This bay may have contained half in acre, and was so completely secluded, that without searching for us, hundreds may have coasted the lake, without our being discovered.

We landed, and while my guide was building a âre, I threw my fly. It was no trouble to procure a supply of fish. Among these lakes, there is no need of laying by a supply for the next meal. Build your fire, and five minutes will suffice to furnish the trout. We had a venison steak, stowed away among green boughs at the bottom of our dug-out. We dined right sumptuously that day, and stretched ourselves for our siesta. In an hour, we shot out from the little bay, and paddled on. We caught some small fish near the shore, and moved towards the centre of the lake, to see if there were large trout in the deep water. 
The experiment was successful. I drew up three crom about sixty feet down, in a few minutes. We returned to the shore, and passed on in our coasting voyage. On the north-west bank, we came to a small cleared spot, where once had stood the hut of a Canadian half-breed, as they are termed. It had rotted. down, many years before, and the rank grass, weeds, and bushes, occupied the spot, where imagination pictured his little garden. It was only imagination, for unless the half of an acre of potatoes and beans, may be called a garden, he never had one. The half. breed, that is half French and half Indian, is a deterioration of both branches of the ancestral tree. $\mathrm{He}$ has all the laziness of the Indian, so far as work is concerned, with none of his industry, ingenuity, and perseverance in the chase. He lives by fishing, trapping, and basket-making. The muskrat and mink, and the skins of the deer, taken on the crust, furnish him with a scanty supply of clothing, groceries; and breadstuffs. He spends his summers and sometimes his winters, by these lakes in the deep forest. Three or four times a year, he shoulders a pack of furs, and with his wife and children, goes out to the settlements, to dispose of his wares, and procure such articles as go 
to make up his absolute necessaries. He encamps on the borders of civilization, for a few weeks, making and peddling baskets, and then puts back to his cabin by the lakes. He has twō or three dogs, with which he drives the deer into the lakes, and catches them with his canoe in the summer, and with which he destroys them on the crust in the winter, a manner of taking them which every true hunter holds in profound abhorrence. He is a stupid, lazy, shiftless specimen of humanity, without skill or sagacity in any department of a woodman's life.

"Squire," said my guide, as we approached the spot where the cabin of the half-breed once stood, "the fellow that owned this-clearin' has been gone a great many years, and· it was a drubbin' I gave him that scared him away. He was meaner'n pusley, and the way I made him understand my feelins' in regard to him, was this: I and old Pete Meigs" (of whom more hereafter) "had been down by the Saranac Lakes, beatin' up a moose pen. We got four moose that time, which is more'n was got at any one time, by any hunters ever I hearn tell on. Well, we were travellin' home on our snow-shoes. This pond lay in our way, and we crossed it down by where our shan. 
tee now stands. We had a shantee there then, and we calculated to put up there for the night. There had been a bit of a thaw, and it had rained the day before, but the wind chopped round to the north, and froze everything as tight as beeswax. The crust was sharp as a knife, and would almost bear a man. We got to our shantee, and started a fire, when what should we hear but the dogs of that blasted half-breed, yelping like death, in pursuit of something. On they came, right by the shantee, with a big buck close before them. It had been a tough winter in the woods, and the poor beast was nothing but skin and bones. Every leap he took was marked by his blood, as the sharp crust tore the flesh on his legs. I was mad enough to see it, I tell you. Well, just by the edge of the lake, the dogs pulled down and throttled the poor critter. I knew very well who they belonged to, and I'd a great mind to give 'em a taste of my rifle; but then I remembered 'twas their nater, and they wan't to blame. So I waited, and when the dogs had killed the deer, they sat down beside it, and began to howl, as if callin' their master to come and finish their dirty work. Sure enough, in a little while, along came the cussed half-breed on his snow-shoes, and fell 
to skinnin' the deer. He was a miserable, stunted critter, too lazy to carry a gun, and wouldn't know how to use it if he had one. He was hunting the deer merely for their skins, and was killin' about a dozen a day on the crust. Everything about them critters is mongrel. He's a half-breed, and his wife's a halfbreed; his children, if he has any, are half-breed. His dogs are half-breed. Whatever he has about him: is half-and-half. He's only half civilized, and when he was made up, there was at least one Ingen and one white man spiled.

"Well, I took the 'sneakin' cuss by the neck, and the way I lathered him with my leather belt, was a thing to stand out of the way of. He yelled louder'n his hounds could bay. I gave him a hoist in the stern with my boot, that sent him about a dozen yards into a snow drift. 'There,' said I, 'you copper-colored cross between an Ingin and a French gander, be off to your shantee, and if your dogs bark again in these woods this winter, I'll stick you through an air-hole in the lake. I give you till next June, to get out of the Shatagee woods. I shall be round these parts, and if I find you here after that, you're a gone sucker.' The darned fool was so frightened, that he turned palo 
as a skewer, and believed every word I said was gospel. I hunted out this way the next season, in July, and sure enough the half-breed was gone; wife, babies, and dogs, all had eut stick, for fear I should eat him without salt. Old Pete Meigs and I bunked in his cabin many a trip after that; but it rotted down at last, and you see the weeds and bushes have taken possession of his potatoe patch.

"I've often thought," continued my guide, "that man is naterally a beast of prey, bent by nater on fightin' with his fellow man,-leastwise he is ready to do so, on slight occasion. Now, I all'ers felt like pitchin' into a half-breed, or a regular Ingin, whenever I met them,--more especially the half-breed; and I do believe I could strangle one, on a less occasion than that of savin' my own life. I was bro't up in a human way, and was made to believe that fightin' and quarrellin', and especially killin' human things, was agin nater, and therefore I never harmed any of 'em, but that one sneakin' cuss. But I all'ers felt 'twould be human nater to larrup 'em wherever I met 'em, and 'twas only because I'd been taught better, that I didn't do it. Edication is a great check on the nater of man. It's that that makes him better'n a half-breed, 
and better'n a regular Ingin too; and its that that keeps his hands off of anybody he don't like."

We spent the day in coasting this lake. We found abundant evidence that it was much frequented by the deer, in the night season. Indeed, as I stated before, we saw them even in the day-time feeding along the margin of the lake. As we rounded a wooded point, that extended some distance into the lake, we came upon a doe and two fawns, swimming in a little bay, into which we suddenly entered. By a vigorous pull we got between one of them and the shore. Terror was stronger in the mother than the love for her offspring, and she bounded away into the forest, leaving them to shift for themselves. I said we cut off one of the fawns from the shore: after various turnings and windings, we succeeded in catching the little fellow, and taking him into our canoe. He was horribly frightened at first, and bleated and struggled desperately to get away; but after a little, finding itself unhurt, and that it could not escape, it seemed to resign itself to its fate; its terror abated, and it lay quietly in my arms. After patting and fondling it in a soothing way, I sat it down loose between my feet in the bottom of the canoe. It made no further effort at escape, 
but looking t.rst up at me, and then at the shore, it bleated plaintively, as if calling its mother to come back. It permitted me to pat it gently, and seemed quieted as I stroked the soft smooth hair on its head. I verily believe that if I had had the means of feeding it, I could so have tamed it in an hour, that it would have followed me like a dog. But to have taken it away, would have been cruel, as it would only have starved in our company. We judged it to have been three or four weeks old, and it was exceedingly fat and strong. We put it unharmed on the shore, and when its "feet was on its native heath," it bounded leisurely away into the forest. We heard it bleat several times, and thought at last that we heard a distant answer, after which all was still.

We procured dry bark and splinters of fatwood, preparatory to going out among the deer in the night. I have stated in a previous chapter, the manner of hunting deer by torch-light. We found them in abundance along the margin of the lake, but we did no more than frighten them. We still had a supply of venison, and after enjoying ourselves at their expense for a couple of hours, returned to our shantee to sleep. 


\section{VIII.}

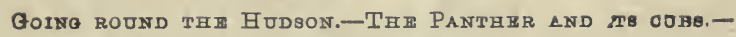
FORTST COOKRRY.

WE rose before the sun. The morning was calm and pleasant. A gray mist, thin and transparent, hung over the lake and crept slowly up the side of the hill. A loon was pluming himself a few rods from the shore, and at intervals, lifting up his clarion voice, that echoed like a bugle among the mountains. We bathed and breakfasted, and once more embarked for a cruise round the lake.

"Pete Meigs," said Tucker, as we paddled leisurely along, "was some in his day. He was an old man in years, five and twenty year ago, but he was a wood man to the last. He killed a ten pronger, a fortnight afore he died, and shot him through the head at twenty rod. He dried up like a mullen stalk, and fied without the aid of a doctor. I helped to bury 
him under a great maple, on the banks of the Shata. gee, and the only land I ever paid for, is four rods square around his grave, I gave a ten dollar bear skin for that, and I've told my children to' see that the old maple remains undisturbed, over the old man's resting place. I buried him seven years ago, and when the summer comes, I miss my old comrade of the woods. It's lonesome on the hills now. I miss the old man's huntin' stories and his knowin' ways. I can't go alone after the moose in the winter, and somehow I don't fancy huntin' them with anybody else. He knowed all about the critters. Huntin' them came kind a nateral to him, and I used to think he could smell a moose, as far as the critter could smell him." "It was curious," continued he, "how old Pete and I took to one another, and while he was old enough to be my grandfather, he always wanted me along, when he took to the woods. I mind once we was down the Hudson, below the falls, where they take people across the river in a boat. We had'nt sixpence between us, and the ferryman would'nt carry us over short of a shillin'. We had our rifles, new ones they were too. Our business down, had been to buy 'em at Saratoga, and that's what had taken 
our money. We had all the fixens, and were putting out for the Shatagee. 'Joe,' said old Pete, to me, 'let's go round" the darned river, and cheat the blasted Ingen out of his shillin'.' 'Agreed,' says I, and the ferryman gtinned when he saw us move up stream. We started for the sources of the Hudson, and we went round the river. We were five weeks away up among the Adirondack mountains. That's a wild country for you, Squire. If you want to see mountains piled up, and valleys scooped out, and lakes, and ponds, and streams, and trout, and deer, and bear, and a sprinklin' of painters, and catamounts, do as old Pete Meigs and I did-go round the Hudson.

"I mind one day we came to an old baldheaded mountain," standing all alone by itself, liftin' its top high above the clouds, and defyin' the storms that beat against its rugged sides. Old Pete proposed, that he go round it one way, and I the other, and meet on the opposite side. It warn't like going round a haystack, 'Squire, you may believe. It was five good miles around, and a smart chance of breaking your neck in the bargain, over the loose rocks that had tumbled down the side of the mountain. Well, I had 
- travelled for an hour, round the base of the hill, when I came to the edge of a ravine, across which my way lay. It was a deep gully worn down by a stream, when the freshets swelled it into a torrent; on each side of it, at the place where I stood, were perpendicular rocks from twenty to sixty feet high. This made me alter my course, and go either above or below, in order to cross over. As. I stood leaning against a great pine, I heard a growlin' and snarlin' sort of a noise, and lookin' across the gulf, I saw on the opposite side, two painters busy in devourin' the carcass of a deer they had caught. It was, may be, twenty rods in a straight line, from where I stood, to the place where they were at work. Now painters are like cats in their nater, and manner of feedin'. They had each torn off a limb of the deer, and lay stretched out on their bellies, eatin' and growlin', not with anger as it seemed to me, but with satisfaction at havin' a pleasant breakfast. I drew up by the side of the old pine, and sighted carefully at the head of one of the kritters and pulled away. I made a good shlot that time, for the ball went right through his brain. He made a convulsive spring, and rolled over, and over, kirkin' and tearin' the earth, till he tumbled 
down the rocks some fifty feet into the gulf be $\mathrm{w}$. As I fired, I stepped behind the tree again to load I warn't an hour loadin' that time, 'Squire, as you s lay guess, and I warn't in such a hurry as not to do it sure, either. Well, I peaked out from behind my tree, and there was the other varmint, walkin' and lookin' around mighty oneasy like. He didn't seem to understand the matter at all. He hadn't discovered me, and it seemed as though he was astonished at the conduct of his mate. He would snuff the ground, and creep carefully down to the edge of the precipice, and look over, as if wondering what had possessed the other to plunge into such an infernal hole. He was evidently displeased with such conduct. The hair on his back was up, like that of an angry dog, and I wasn't sorry that he did'nt see me, and that there was a gulf between us. After walkin' round, and lashing himself with his long tail, he set down on his haunches, and looked towards where I was standing. His breast was towards me, and I sighted him $b_{y}$ the side of the tree long and sure, and pulled. You ought to have seen the bound he made, 'Squire. He was twenty good feet above the brink of the precipice, and I'm blamed if he didn't clear it, and go cver and 
over, down into the gulf, and I heard him strike the bottom, as plain as I heard the crack of my own rifle.

- "My two shots were answered by old Pete Meigs's rifle, and I fired again as a signal, and waited for the old man to come round. Presently I heard his halloa below me, and I went to meet him. 'He'd hardly believe my story, but we went up the gulf, and found my two painters shot dead enough, and their bones broken by their plunge down the rocks, in the bargain. One of them was a she one, and from appearances was the mother of a family, Old Pete declared he'd have her whelps. We went round to where I fourd them eatin' the deer, and the old man, after examinin' the signs, as he termed them, started off toward the head of the gulf. We searched the rest of that day, but found nothing. We were satisfied, however, that we war'nt a great ways from the old painter's lair, for we found, scattered about, the bones of deer, and other animals they had devoured. We camped on the mountains that night, and about daylight, old Pete started from his bed of boughs, and cocking his ear for a moment, cried out, 'that's them.' I listened, and heard a whinin', moanin' sort of a noise, like a kitten's that's lost its mother. We started 
oft' in the direction of the sonnd, and at the head of the gulf, under a ledge of rocks, we found three young painters, nestling in a bed of leaves, snug enough. They were about as large as cats, and plump, and fat, and hungry as anything. One of 'em we knocked on the head, and each of us took another, and went ahead. We fed 'em on fresh meat, and bro't 'em out safe. We sold them to a menagery man for twentyfive dollars a piece. They were harmless, playful things, and one would hardly think they'd grow up to be such fierce and ugly customers. Old Pete Meigs and I made fifty dollars a piece that trip round the Hudson, and had a good time of it too."

On the west side of the lake, some distance below our shantee, the water was shallow for a few acres. Here the pond-lilies grew in profusion, covering the surface with their broad, round leaves, in the midst of which sparkled, like silver, a thousand beautiful white flowers. These lily patches furnish rich pasture for the deer, and we noticed paths leading into the forest, which were trampled almost like those leading to a sheepfold. It being towards night, we sat ourselves quietly down behind a thick clump of bushes, on a Jow promontory, to watch for the deer as they should 
come to the water to feed. We were careful to select a spot for our hiding-place, so situated that the breeze would blow towards us, from the direction in which we supposed they would enter the water to feed. This is necessary, as the deer will otherwise scent the hunter a long distance, and keep beyond the reach of his rifle. We sat silent for perhaps half an hour, watching, when an old buck walked cautiously from the forest, and stepped into the edge of the lake. Here he paused, and looked in every direction about him, and seeing that all was safe, waded out three or four rods from the shore, and commenced feeding on the stems of the pond-lilies. He was within fair range of my rille, but we let him feed on. Presently a doe came down from the woods, in the same cautious man. ner, and she, too, began to regale upon the rich pasture that the lake afforded. We sat there until four were quietly feeding,-all in fair sight, and within range of my rifle. Selecting a small one that, from where I sat, seemed to be in the best case, I fired and brought him down. The report of my rifle and the smoke frightened the others hugely, and with a snort they leaped from the water, and went crashing and whistling up the mountains. The old buck didn't 
seem to understand the matter at all. He was greatly alarmed, to be sure, but we heard him whistling every few minutes, and beating the ground with his feet, as if bounding up and down, some forty or fifty rods away in the forest, for a long time. He was shut out from our view; as we were from his, by the dense foliage between us. At last we heard him bound away in earnest, and all was still again. Our deer was a small two year old, and exceedingly fat and tender. We supped on his sirloin, roasted before the fire that night, and that with a relish seldom equalled. The science of roasting a sirloin of venison in the woods, is not to be despised. One must understand it to succeed well. Two crotched sticks are set up before, and at a proper distance from the fire, and from each other; across these in the fork, and at the height of about six feet, is laid another. The venison is suspended from this cross-bar by a string, close enough to the fire to roast, and is kept constantly turning, so that all sides get an equal portion of the heat. We used a pint basin for a dripping-pan, from which, ever and anon, we basted it with the rich gravy that dripped from it while roasting. Birch bark, just peeled from the trees, served for platters and plates 
when it was done; and let me say to you, that our venison tasted to us better that night than though it had been dealt with in the most artistic style of cookery, and spoiled by a profusion of French condiments. 


\section{IX.}

Thi Lost Caitd - ShaOr.

"WHAт a queer matter it is, Squire," said Tucker, as he knocked the ashes from his pipe, after supper, by tapping 'the inverted bowl against his left thumbnail, "that all living things should stand in fear of a man. From the fierce painter to the timid hare; from the eagle, that looks with a steady eye at the sun, as he soars beyond sight into the sky, to the sparrow that chirrups in the hedge; all ${ }^{\circ}$ flee from the face of a man, and that, too, though they never saw one of his kind afore. Some animals, to be sure, when they become better acquainted with him; learn to fear him less, and live in his neighborhood with less of dread; but such animals are his slaves, servin' him with patient and slavish fear. Among all the dumb beasts, the dog alone seems to live on friendly terms with him. Now, Squire, tell me why it is that all livin' 
things, save the dog alone, seems to regard man as their nateral enemy. The little trout, even, that suns himself in the ripple, darts away from his presence, and hides himself under the bank. Is it because he is , always warring against 'em? Killing 'em for his pleasure, or enslaving 'em for his profit? I all'ers tho't that the love of unrestrained freedom, was a nateral element in all livin' things,-strong as life itself. The moose scents a man afar off, and hides him. self away in the deepest recesses of the forest, or the darkest shadows of the swamps. The painter, unless made bold by hunger, lays silent and still in his larr to escape him. The bird takes to his wings, and flies away from him. Among all the wild or tame animals, the dog alone seems to regard him as a friend and protector, and stays willingly by him, as a con firin' and faithful servant, watchin' over his safety, and lookin' to him for protection. By the way, Squire, the $\mathrm{dog}$ is an animal that a man may take profitable lessons of. He never deceives his friend and master. He never ceases to love him; when all other friends forsake and flee from him, he stands by him. In hunger and cold, in sickness and distress, he never leaves him. All he asks is food, and even that isn't 
made a condition of his servitude or friendship. I love my dog," said he, as he put his brawny arm around his shaggy friend's neck, and drew him to. wards his bosom, and I could see by the sparkling eyes of the animal, as he licked his master's face, that the love was reciprocal.

It may not be amiss to introduce to the reader, the friend that held so high a place in my guide's regards. That I have not done so before, is perhaps blameable. He started with us into the wood, glad enough, as it seemed to me, for the privilege of doing so. He was a large, powerful animal, of no particular breed or . beauty. His coat was shaggy, and of light gray color. The blood of the terrier, the stag-hound, the Newfoundland, and cur, evidently mingled in his veins; and it may well be that the mastiff and stubbornlycourageous bull-dog might have been reckoned among his ancestors. He had a large head, and two of the most active, intelligent eyes that I ever happened to see belonging to a dumb animal. He had, from accident or design, been shorn of his tail, excepting: a short stump of about six inches. His ears, ton. had been trimmed, as my guide said, when he was a pup, to make him look sharp and active. His looks did 
not belie his character for courage or intelligence. When we desired it, he went with us,-close at his master's heels when we travelled, or sitting quietly in the bow of our canoe, or on our raft, when we floated on the water. When we did not desire his company, we left him at our shantee, placing him as a watchman over some garment that we would leave in his charge. Where we thus left him, we were sure to find him on our return. He would greet us as we came back, rejoiced to see us, and would say as plainly as a speechless animal could say, that he had jeen a faithful watcher in our absence.

"That dog," resumed my guide, " has knowin' ways, and I sometimes imagine that he thinks like a man. That he has strong memory I know, and that he sometimes gets at the meaning of things in a human way, I do believe. Two years ago this summer, my little girl went into the edge of the woods one day, to pick berries. You know our little clearin' is mostly surrounded with woods, and on two sides the forest stretches away for fifty miles or more. The time for her return passed away, and she didn't come back. Her mother and me became alarmed; we went all round the edge of the woods, and called, and called 
but no answer was returned. Then we knew she was lost; and, Squire, you never can know the bitterness of the thoughts that come into a parent's heart, when he knows that his little one is away off, lost, all alone, wandering in the wild woods to starve, and die, or be torn in pieces, and devoured by the beasts of prey. My boy was away to the mill, and Shack (the name of his dog) was with him. The sun was going down behind the mountains, and no tidings of our little one reached us. My wife's heart was broken with fear for her poor girl; and although a strong woman, her nerves were all gone with anguish. I carried her to the house and left her in charge of my boy, who had just returned. I shouldered my rifle, and calling Shack after me, went out to pursue the search. I called, and called, but could hear no answer. Presently Shack seemed to understand something of the trouble I was in, and though I never knew him to leave my heels or disobey me before, he became terrible uneasy like, starting away every few minutes, and returning with the greatest reluctance. Now it never occurred to me that Shack, after all, was the best searcher for the lost one. I was so troubled, that I forgot the noble instinct and sagacity of the 
dog. At last, when I called the name of my girl, Shack, as if he'd made up his mind, darted away, and utterly refused to come, back. His ways was strange to me, and I was kind o' scared by his behavior. He coursed in a circle, growing wider and wider, running at the top of his speed, with his head down, as if in pursuit of something, till I lost sight and hearing of him, and like my little girl, I was alone in the forest. The dark night had come on, but I struggled forward, stumbling at every foot fall in the darkness, calling every few minutes, my daughter's name. The echoes of my voice died away into stilness, or was answered only by the startled cry of some night bird.

"I sat down to rest, and concluded in my hopelessness to wait for the daylight, to pursue the search. It was a sad, sad thing, Squire, to sit there in the silent darkness, and know that my little girl too, was alone in those dark wide woods, shivering with fear, and calling upon her father to carry her home-seeing, in her terror, great round eyes of wild beasts, glaring upon her from every bush, and hearing their angry growl in every forest sound. I heard the solemn hooting of the owl. and his wild scream, and 
thought what terror it would carry to her little heart. I heard the dull creaking of some great tree, as it rubbed against another, and while to me it was a familiar sound, yet how full of horror it would be to her ears. She was a timid, tender thing, and I thought all these sounds, and the darkness would kill her. I sat there may be an hour, when I heard a crashing of the brush on the way I had come, and in a moment Shack bounded up to me. He was panting and lolling, as if he was just from a long chase, but he seemed overjoyed and crazy as a loon. He bounded around me, and jumped upon me, and whined and barked in a way that I had never seen a dog do before; and it seemed out of place that he should be so merry, when my own heart was so sad. He would jump upon me, and bound away, and then stop and look back, as if asking me to follow him. Scolding did no good, he would not heed it. All at once, light broke in upon me. He has found my child, I cried, and is telling me to go to her. I wasn't long in obeying him, you may be sure, Squire; and when I start. ed in the direction he indicated, he became at once quiet, and steady before me, as if satisfied that he was understood. We had travelled thus what seemed to 
me a long distance, when a thought seemed to strike him. He stopped and listened a moment, and then dashed like a race-horse away. Calling did no good: he was ought of sight in a moment, and in less than a minute I lost the sound of his bounds, as he dashed through the woods. I followed in the direction as fast as the darkness would permit. It was some fifteen minutes, when I again heard him coming at full speed to meet me. He seemed as joyous as before, and after jumping and barking for a moment around. me, took his post in front again, and we passed on. After awhile, I called out my little one's name, and, $\mathrm{Oh}$ ! it was a sweet and pleasant answer to my heart, that came faintly back, 'father, I am here.' Away bounded Shack again, and you may believe, Squire, that I wasn't long in following him. A few minutes, and my little one was in a happy man's arms, safe from harm, but trembling with the horror of her night in the dark still woods.

"She had wandered in search of berries, beyond the sight of our clearing, and when she turned to go home, became bewildered and lost in the mazes of the forest. She wandered on until night, and then, ir mortal terror, sat down in the darkness to weep, and, 
as she thought, to die. Frightened as she was, sleep weighed down her little eyelids, and she slept. She was awakened, she said, by something licking her little bare feet and face, and she started up screaming in affright, thinking it was a panther or a bear; but Shack leaped, and whined, and yelped in his great gladness around her; and when she knew it was him, she felt safe. He stayed by her a few minutes, and then darted away, and she was alone again, and as frightened as ever. She dared not call, for fear the panthers and bears would hear her, and come and tear her to pieces. She had sat there a long time, when something stirred among the bushes near her, and she screamed out in her terror. It must have been that Shack heard her, as he was guiding me forward at the time he left me, though the sound didn't reach my own ear. A few minutes after, Shack was by her side again, glad enough to find her safe. He soon left her; and when she heard my voice, she knew he was leading me to her. We were two good miles in the woods then, but, Squire, that little girl that I loved so dearly, that had been lost in them great wide woods, and been found again, was light as.my own heart, as I bore her 
home, and placed her in the arms of her mother; and you needn't wonder that we've loved Shack more'n ever, since that sorrowful night."

There's a beauty in the deep forest of a moonlight night, that we of the city but faintly dream of. Our shantee was on the banks, a few rods from the lake, with a slope of green between it and the water. Above us the trees, stretching out their long arms, formed an arch, through the vacant spaces of which, the stars peered down, while before us we looked away over the bright waters, on which the moonbeams played, as the night-breeze sent the mimic waves, rippling in tiny billows, over its bright surface. Ever and anon was heard the splash of the trout, as he leaped from the depths, and the deer, as he waded from the shore, to feed on the aquatic pastures; and - the frog, as he leaped from his rock, and sending forth a sharp quick note, plunged into the lake, to hide himself beneath the weeds and water-plants. Beyond and across the lake, the bare head of a conic mountain shot skyward, throwing back the moonlight from his glistening brow, while the night-winds sighed and monned among the old forest trees that clustered 
around his base. The night was tor beautiful almost for sleep. Yet we laid ourselves down upon our bed of boughs; slumber soon stole over us, and we passed. away in the land of dreams. 


\section{X.}

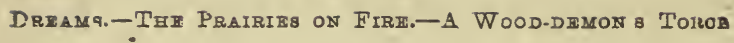

Dreams! What are dreams? Why is it that, in the silence or stillness of night, when the body lies insensible in the repose of sleep, that strange visions rise up before us, and we seem to wander amid scenes that belong not to the living world,- - visions that war with natural laws, and yet seem, to our senses, consistent as those of real life? A new world opens before us, --a world governed by different laws; we possess natures, antagonist to our real ones, and are endowed with attributes that belong not to humanity. We take to ourselves wings, and fly like birds through the air; we rush unharmed through the deep waters, and plunge urhurt down profound precipices; we talk with dumb animals, and hold communion with those who have long been slumbering in the grave. And 
yet in all this there seems to us at the time, to be no violation of natural laws, nothing strange or mysterious. We recall them to our waking memory, and wonder how it could be, that even in sleep, we did not detect their impossibility. Why, and how is this? 'Does the spirit leave for a time its prison-house, and wander, in fact, in a new and real world? Are the things we dream of, sober realities, existent as those we see while in our waking hours? Are there many worlds, one within or around another, between which the spirit and the body vascillate? When the body sinks to slumber, does the spirit, in truth, visit other worlds, participating in their scenes, mingling with other beings, and holding converse with other intelligences? Who can tell?

As I slumbered upon that bed of boughs that night, strange visions passed before me. I was away in a new world, and yet all that I saw was familiar; nothing seemed strange to me. I was among beings that I seemed to know; not men and women, but rather the spirits of men and women; not as those that had died, and whose bodies were mouldering in the grave,-they had form, but not substance; shadows that moved and spoke; that seemed formed 
after the similitude of men and women, but through whose forms the sunlight passed. I possessed all the attributes of humanity, save a real, tangible body. Hands, and limbs, and body, I seemed to possess,paipable to the vision, but not to the touch. Hunger, and cold, and heat, and pain, were things that seemed to me unknown. Space and time were as nothing. I passed at once without effort, like thought, from place to place. We think of scenes far distant from us; memory calls up the stream, the lake, the meadow, the great trees, the cottage, and the garden; we say thought wanders away to such scenes. Well, this seemed to be with me a reality. If I thought of a scene, a locality, hundreds or thousands of miles away, at once $I$ was there.

I thought of Rome, of the great St. Peter's, and there I stood, beneath that gigantic temple. I thought of the pyramids, and stood at their base, and talked familiar with the mummies that slept within those granite piles; I thought of Waterloo, and there I stood, surveying that mighty conflict. I saw legions of men, hurled against legions of men. I heard the roar of the cannon, and the rattle of musketry. I saw the smoke of battle, wreathing up from blazing bat. 
talions. I saw the flashing of swords, as vast squadrons of horsemen mowed down the flying foe. I heard the groans of the wounded, and the wild shrieks of the dying. I passed unharmed through the conflicting hosts, looking upon the dying and the dead. Wherever I chose to be, at once I was there. How I passed I know not,- - the fact alone I remember. As my body was intangible, it was unaffected by the elements. Fire would not burn it; water would not drown it. I could walk on the bottom of the ocean, with a thousand fathoms of water above me. I could plunge into the volcano's seething cauldron. Rocks would not crush me, and precipices, down which I plunged, were harmless as the level plain. Such a being was I, and such were those around me. Shadows, mere intellectualities, existing palpably to the vision, having form and comeliness, but unfettered and unconfined by a fleshly body. Of such a body, it seemed to me, I had never heard, save in the wild theories of some metaphysical dreamer. Its existence was a subject of derision, and those who upheld its reality were regarded as idle visionaries,-nay, as profane rejectors of philosophical truths.

"A change came o'er the spirit of my dream." 
I was away in the midst of the broad prairies of the West. They lay there, as they came from the Creator's hand. The eye of civilization had never before looked upon them, and no civilized man had set his foot upon the green grass that vegetated upon their bosom. All around me were vast plains,--treeless and shrubless as a shorn meadow. Away off, on the one hand, hanging like a blue dim shadow upon the horizon, was a belt that I knew to be timber, while on the other, on the very outside boundary of vision, loomed up the lofty peaks' of the Rocky Mountains,-moveless and fixed, like sentinels of God, watching the boundless plains beneath them. The tall grass waved, like vast fields of grain in the summer winds; rich flowers of the most gorgeous hues, sent their wild fragrance abroad on the air, charming the vision by their glory, and entrancing the senses by their sweetness. In all this vast plain, I saw no living thing. All around me was silence; vegetation alone seemed to live there, and that grew and flourished in richest and wildest luxuriance. It was like a vast garden, planted and nourished by the hand of nature, unaided, as it was unchecked, by the ingenuity or the industry of man. Suddenly a blight 
seemed to pass over that vast plain; the flowers faded; the tall grass shrivelled and died; the leaves on the rank weeds rolled together, and were blown away, by hot winds that swept over that ocean of land; vegetation withered into a gray and sapless mass, standing where it grew; the streams, that were wont to move in sluggish and tortuous windings, were dried up, leaving channels like the trails of immense serpents; the, blight of drought was upon all nature about me.

As I stood, wrapped in contemplation of the immensity around me, a dull heavy sound fell upon my ear, like the rumbling of a thousand carriages over the rough pavements of a far-off city. Turning in the direction whence the sound seemed to come, I saw in the distance vast herds of deer and antelopes, flying at wild speed towards the spot where I stood. Behind these came an army of elks, their stately horns glancing and waving in the sunlight, seemed like a forest of dead, low, barkless trees. Behind these came thun. dering down again, millions and millions of buffaloes, making the earth tremble with the weight of their rushing and countless hosts. For miles and miles, in width as well as in depth, this vast herd covered the 
plain, bellowing and roaring in seeming terror at some terrible destruction behind them. Then came vast droves of wolves, panting and howling, in immense numbers, with jaws distended, and tongues lolling out, like hounds wearied by the chase. None seemed seeking for prey; a mortal terror was upon all; all were fleeing, as it seemed for life, towards the belt of timber land visible in the distance. These vast waves of animal life swept by me; the roar of their countless voices died away, like the tempest in its onward flight. Then I saw the reason of their mortal terror. Away in the distance, was a dense line of dark murky smoke, wreathing and twisting heavenward, wrapping earth and sky in its sombre folds. On came the-fearful visitation, preceded by a line of fire athwart the whole of that vast plain, flashing and glancing upward as new fuel was grasped by its devouring tongue, and it was hurled onward by the rushing winds. On it came, crackling and roaring, like a mighty bjllow of flame, devouring and overwhelming all things in its terrible career. Onward and onward it came, with the speed of the war horse, and the roar of the tor nado. Before, it was destruction; in its rear, the blackness of desolation. Far as the eye could reach, 
on the right hand and on the left, it moved in a line of fire, leaving no escape save an onward flight. I stood spell-bound as it approached; that mighty prairie seemed rolled up, as it swept along, like a vast scroll, while the impenetrable obscurity behind it was like the darkness that was of old on the face of the deep. It approached-it surrounded-it enveruped me within its folds, when-I awoke, and behold it was a dream! and "yet not all a dream." The fire we had kindled in front of our shantee, had crept along the dry leaves until it reached the foot of a dead fir tree, among whose thick and withered branches, a wild grape-vine had spread its thousand tendrils. That too was dead; the fire had crept up the dry trunk of that dead fir tree, and having reached the network of vines and sapless branches, it burst out into a brilliant flame. When I started from my sleep it was flashing and creaking, and swirling upwards, lighting up forest and lake, like a vast torch in the hand or some gigantic demon of the woods.

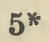




\section{XI.}

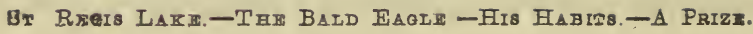

THE morning broke clear and bright. A bath in the clear cold waters of the lake, and a breakfast before sunrise, nerved us for our day's journey towards the Saranac Lakes, some twenty miles distant. It was by no means our intention to travel all that distance in a single day; that, would be to turn pleasure into toil. I started from home, with a determination to take things easy; and though prepared for some labor, was by no means prepared make that labor over severe. As I have before stated, my guide was familiar with all this wild region, and there was no danger of becoming bewildered; besides, the country is every. where intersected with streams, and should one become "lost in the woods," it would only be necessary to follow one of them and he would be sure to $\operatorname{com} \theta$ 
out ere long, at some lake which he would recognize, or if not, he would arrive at last, at some settlement, The way might be longer or shorter, according to circumstances, but he would find no lack of food, always supposing that he carried a rifle, and was in possession of a hook and line.

We followed the course of a stream, which formed the inlet to Meacham's Lake, for some five or six miles, until we struck a township line of marked trees, and then, diverging from our course for near a mile, came to a neat little lake, covering, perhaps, two or three hundred acres. Here we bivouacked for the remainder of the day and night. Having erected our shantee, we lay down to rest. In an hour we were up again, refreshed, and ready for such amusement as the water and woods afforded. Our stock of pro. visions had become reduced to very simple fare. Sea biscuit, pepper, salt, and a little tea, constituted our whole supply. But these, with venison and trout, and such appetites as a man finds in the woods, answers the purpose of more delicate food to a dainty taste. We constructed a catamaran of poles, and during the afternoon, coasted, and crossed the lake. Wa found, that like the others we had visited, it 
abounded in trout-large ones in the deep water, and the smaller speckled trout, near the shore. The deer, too, from the paths leading into the forest, seemed to be plenty, and at sundown I shot a small one, as he was feeding on the water-lilies near the shore:

In the morning, we passed on to a pond or lake, six or seven miles distant, and near the centre of the township. This lake is some three miles in length, and varying from half a mile to a mile in width. It bore the same general aspect as the other, surrounded by old primeval forests, overlooked on one side by high hills, and skirted on the other by a valley that stretched away to the east, through which flowed a noisy brook, literally swarming with small speckled trout. We dined on sea-biscuit and broiled trout, on the banks of this pond, and then struck for St. Regis Lake, some six ' miles distant, and on the other side from us a range of high hills. It was a warm day, and that six miles was toilsome enough. They cost us much labor, and not a little perspiration, but by six o'clock we descended the hills, where at their base, in the deep shadows of the mountains, lay the lake, calm and still, and transparent as a mirror. It was a welcome sight to our eves, that beautiful lake, sleep. 
ing there, so silent and alone. We had travelled some twelve miles that day, over a country rough, and toilsome at best, but rendered doubly so, by the tangled brush, the fallen trees, gullies, and broken rocks, and boulders, which lay in our way. We erected a shantee, and supped heartily on partridge and trout. We retired early that night, and, despite the sharp sting of musquitos, and their ceaseless trumpeting, slept soundly and calmly till dawn.

Here again, my guide had, in former years, constructed a canoe, which we found, where he had hid it the previous year, and having caulked, we launched it on the still surface of the waters. The St. Regis may be four or five miles in length, by a half a mile or more in width, bending around the bluff end of a hill, somewhat in the shape, though less curved than a horse-shoe. On the opposite shore the land is more level, and the shallows reach far out into the lake. On these shallows, a profusion of grasses and lilies, and water weeds grow, forming rich pastures for the deer, and a secure hiding place for the many broods of wild ducks, that we saw sporting round their care. tul mother, as she watched with sleepless vigilance over them. 
My' guide left his pack at the shantee, and giving Shack a hearty meal, ordered him to "watch it." We started in our little craft to cross the lake. As we rounded a promontory, some half a mile from our starting place, we noticed a majestic eagle, perched upon the dead branch of an ancient hemlock that leaned out over the lake, a quarter of a mile, perhaps, distant. These birds, will sit thus for hours, pluming themselves, or watching in quietness the lake, for some heedless duck that may trust himself too far from the shore. We landed quietly, and I started with my rifle, to endeavor to approach near enough, to bring him down from his lofty perch. Happily the nature of the ground aided me in this; a path worn by the deer, led round the lake, along which I could move, without disturbing the bird. I stole cautiously along, and having approached within range of my rifle, sighted carefully by the side of a tree, and fired. The ball struck the outer joint of his wing, and down came his feathered majesty, flapping and turning over and over, until he struck the surface of the lake. Having regained the canoe, we started to secure our prey. He was, indeed, a noble old bird; his head and the feathers of his neck, and of his tail, were 
white, while the rest of his plumage was of dark brown, approaching the black. He was not that drooping, dingy, rough, and unwashed thing, that we see in cages, and have pointed out to us, as the great king of American birds. As we approached, he made a desperate effort to fly away, failing in which, he faced - us with a look of defiance. There was a wild fierceness, an intensity in his eye, that spoke of the rapacity, as well as the courage of his nature. As we came near him, he opened his great beak, and hissed like a . serpent, defiance at us. A blow on the head with a pole, after a brief struggle, stilled him, and we drew our noble captive into the boat.

I am not sure that I felt precisely satisfied, for having slaughtered that princely bird. Me, at least, he had never harmed. He had slain, only to sustain his own life, and had killed, only to supply himself with food. He was following only the instincts of his nature; but was not I, also, following mine? This was a question, which I left for settlement, to those more cunning in casuistry than myself. In the meantime I retained his great quills, a few sof feathers of his plumage, and one of his claws, as trophies, and left his carcase to float on the scene of his own car. 
nuge. He was like some great human heroes, using his strength for pillage, and his power only to destroy. I had, at least, removed one cause of terror, from the anxious hearts of the mothers of those harmless broods, that I had seen sporting near the opposite shore, the destruction of which, my victim-was no doubt watching an opportunity to achieve.

"Squire," said Tucker, as we shot into a little bay, so shaded and delightfully cool that we could not resist the temptation of making it a resting place, "I've hearn people call the eagle a noble and magnanimous bird ; but it ain't so. He's a cussed thief and robber,as well as a murderer of things weaker than himself; he's a mean, selfish critter, that takes no pleasure in being sociable and friendly like; he's always hunting for something to devour, and when he gets hold of a poor duck or rabbit, he flies to some solitary spot, all alone by himself, and eats it. He never invites anybody to dinner, and is sure to pick a quarrel with every bird he meets. I've hear'n tell of the eagle and his mate; but I've been about these lakes twenty odd years, and have seen a many of eagles, but I never saw two together more'n two or three times, and they were always quarrellin' and fightin', till one or the 
other had to give in, and leave. I suppose it must be that accordin' to nater, they go sometimes in pairs, else the breed would run out, but I never saw two together on terms anything like friendly. I mind, once, away down at Tupper's Lake, old Pete Meigs and I was layin' off under a grape-vine, that had crept up the trunk of a great elm, and stretched its'slender arms out all among the branches, and spread its great round leaves all over them, so that the sun couldn't pass through, we saw one of them birds settin' on the limb of a dry tree that leaned out over the lake. Presently we saw a dark shadow glancing over the water, and what should it be but another great eagle, making a stoop at the one settin' on the limb. He missed his aim, however, and round and round they went, driving and striking at each other, and screaming like owls. Once in a while they'd come together in the air, and, Squire, the way the feathers flew, was a caution to see. They seemed to grow madder and madder, till bye and by they had a regular clinch, and I'm blamed if they did'nt both come down together plump into the lake. This kind a cooled their fightin' humor, and they got out as fast as they could. One went back to his perch on the limb, and we saw blood 
on the white feathers about his neck. The other soared away, and we watched him till he became like a speck in the air, and then lost him in the depth of the sky. Now, there was room enough for both of 'em there, and prey enough for 'em both, too. But the one wanted. to be alone, and the other would'nt let him, and so they must have a fight about it.

"But, Squire, I said the eagle was a thief and a robber; and when I tell what I've seen, you'll say I'm right. I once saw a fish-hawk over at the Shatagee make a dive for a trout, and catch him. He might have weighed two pounds, and the hawk had hard work to raise with him from the water. But he did rise with him, and what was curious to me, seemed anxious to get as high as he could. He kept strugglin' upward, and screamin' in a most uncommon way, until he'd got up may be four or five hundred feet, when I saw what his trouble was. From above him, I saw a bald eagle comin' down, like a streak of chain lightnin', right upon him; the poor hawk had no choice but to let go the trout he had provided for dinner. This was what the eagle was lookin' for, and swift as a bullet he dropt after the fish, and, Squire, how it could be I can't tell, but 
I'm blamed if he didn't grasp that fish in his great claws, long before it reached the water, and flew across the lake to a great rock, and devoured it. Now, I've no doubt he'd been watching that fish-hawk from his place, away up in the sky, to rob him of his lawful spoils. I say, again, the eagle's a robber and a thief, - usin' his strength to plunder; and I give him a bullet whenever he comes within range of my rifle. He's a solitary, and a selfish bird too. I have seen their nests, and watched to see the old one bring food for her young; but at such time I never saw the father of the family. If there was one, he didn't think much of his home or children, for I never saw him about. May be he was away preparin' meals for his wife; but he didn't stay much about home, that's certain. I mind once, old Pete Meigs and I was up among the Adirondacks; about the upper end of Liong Lake, and the hundred other little lakes that lay there among the mountains. On one side of one of 'em, that I never heard the name of, is a high mountain, around the point of which the lake bends, and where the rocks rise high, away up in an almost a perpendicular precipice, we saw one of their nests. It was built among the branches of a fir tree, that stretched 
out from the clefts midway up the rocks, and shot upward towards the sky, like the mast of a tall ship. Sticks and dry brush had been carried up, forming a nest larger than a corn basket. We watched for days, while we were there, and saw the mother bringing food for her little ones. Sometimes it would be a duck; sometimes a wood-rabbit; and now and then a fish, that she'd plundered from a hawk. She always seemed to be busy; but the he one we never saw, and, in my opinion, he took no charge of the family" 


\section{XII.}

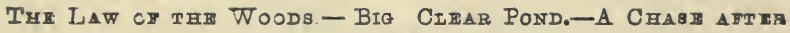

A DHFr.-A MoOsh PATH.

AT evening we returned to our shantee, with a supply of trout, and a small deer that we had shot. We found Shack watching his charge, and mighty glad he was to see us too. Like us, he relished his supper that night.

"Tucker," said I, as we sat smoking our pipes after supper, and listening to the hooting of the owls, and the song of the whip-poor-will, "do you know that we have been breaking the law, and incurring a heavy penalty, by the killing of the deer, upon which we have been supping ?"

"Squire," said he, "I've hearn tell of such a thing, and suppose it's so, but I never read the law, and shouldn't regard it much if I had. Not that I believe 
in disregardin' the law, as a general thing, but thas one don't apply, and warn't ever intended to apply to the Shatagee Woods. Away off here, among the lakes and mountains, there's no justice of the peace, nor constables, nor witnesses either, unless we tell on one another. And if there was, there's a law above the statut' book that justifies us-the law of hunger 1 and of necessity. It is the same law that makes the eagle pounce upon and devour the harmless duck, that makes the fish-hawk seize his prey, and the painter destroy the deer,- - the law of instinct and selfpreservation. I often think, he continued, "there are two kinds of laws, differin' as widely in their naters as light and darkness. The one bindin' everywhere,-in the forest, as in the settlements; in the fields, as in the cities; to break which would be wrong of itself. The other, bindin' only to accordin' to circumstances. As regards the one, the wrong consists in the breakin' of it, whether the world knows of the breach or not. As to the other, the sin is in being caught in its violation. There's one law for the woods, and another for the settlements; one for the deep forests, and another for the city. If I build a shantee of hrush on a vacant lot in a city, and live there with my dog, I'm taken 
up as a vagrant, and sent to the penitentiary. Why?

Because there's houses enough in a city for all to sleep in, and it's onnateral to sleep outside of 'em, and the people think I'm around for no good. But who ever thought it out of the way of nater, for us away out here, where there ain't any houses, to sleep in our shantee in the depths of the Shatagree? If I find a loafer in your street, torterin' and abusin' a dum animal, and I kick him by way of caution, I'm taken up for 'salt and battery, as it is called. Why? Not because the fellow didn't deserve a kickin', nor because I didn't sarve him right, but because there's courts, and constables, and law, by which he may be punished in a regular way. But who would think of takin' me up, for kickin' that cussed half-breed I told you of, for slaughtering the poor deer on the crust? If in the night-time, in the streets of your city, I think to amuse myself by singing at the top of my voice, I'm taken to the watch-house, and locked up. Why? Because I'm disturbin' the sleep of the people, alarmin' the timid, shaking the nerves of the sick, and breakin' the public peace. But if away off here in the deep forest, alone among the lakes and hills, I choose to strike up Hail Columby, whether to amuse myself, or 
wake up the sleeping echoes of the mountains, to hear my voice thrown back by the Adirondacks, who will say I have broken the peace, or disturbed the quiet of the people?

"The truth is, Squire, away off here in the wild woods, the law you speak of has no force. If I'm hungry, I've a right to furnish myself with venison. The law of nater and necessity permits it, and that I say again, is higher than the statut' book. But I've no right to steal your rifle, or murder you, even in the deepest and darkest recesses of the Shatagee.

- Why? Because the law' of nater and of conscience, of the great God himself, as well as of man, forbids it. And though you might rot where I slew you, and no man look upon your bones, though I myself should escape suspicion, yet the guilt would be as deep, and the wrong as great, as though done in the highways of the settlements, or the crowded streets of a city. But killin' a deer here in the woods, that belongs to nobody, that no one ever before saw, that no live man can lay any claim to, is another thing, even though there may be law agin it. It don't go agin my conscience to break such a law, and I don't care who knows it. If by killın' a deer when I want steaks for 
breakfast, or his rump for dinner, I do go agin a printed statut', I can still look you in the face as an honest man, because that statut' don't reach the Shatagee woods, nor the lakes and mountains of the Adirondacks.

"Good," said I; "Tucker, you talk like a Judge, and without knowing it, have hit upon the legal phi. losophy of Blackstone."

"I don't know," he replied, "who Blackstone is, but that's the philosophy and the law of the woods, as we understand it."

We started next morning for Big Clear Pond, as it is called, a circular sheet of water, four or five miles in circumference, and some three miles from St. Regis Lake. Our way again lay over a range of hills, cov.. ered with tangled brush, and loose boulders, that made travel exceedingly toilsome.' This range of hills divides the head waters of the St. Regis River from those of the Saranac. The lake is properly named. Its waters are clear, and one can look away down into its depths, and see the white pebbles on its gravelly bottom, twenty or thirty feet beneath him. It is exceedingly cold too, and if the trout with which it abounds, are not contented with their home, they are not capable of appreciating a good thing. 
This lake affords little pasture for the deer. Its shores are bold, and it produces none of the lilies and grasses, which so abound in the other lakes we had visited. We found a canoe here that had been left adrift, or had been floated away from its hiding place. It lay upon the beach, as if it had drifted there when the waters were high, and was left high and dry when they receded. It was without oars or paddles; the latter, however was soon hewn out by my guide, and we launched it, for a voyage round the lake. We spent the balance of the day on this beautiful sheet of water, and slept in a shantee on its shore. Here, for the first time, we had no prospect of taking a deer, from such as should come to the water to feed; but, we were not, therefore, to be without venison. I have before said that Shack had a sprinkling of the Stag Hound in his veins, and would as a consequence, follow a track-not as staunch, certainly, as one of purer blood, but sufficiently long to satisfy our purpose here. So long as he would follow, he kept his game in active play, and his half hour always made a deer exceed. ingly busy. My guide stationed me at a point where a low ridge terminated in the lake, as the place where the deer would be most likely to take to the water, 
and then started up the valley with the dog to put him on the trail. I had been waiting, perhaps half an hour, when I heard the quick, sharp, currish yelp of Shack, some distance off, on the side of the mountain. In a few minutes $I$ heard the long bounds of a deer, as he came crashing through the brush towards the lake, with the dog some six or eight rods behind him, barking quick and sharp, at every jump. The deer leaped into the water, some eight rods from me, and struck out for the opposite shore. A ball from my rifle stopped him-I was soon along side of him with the canoe, and passing my hunting knife across his throat, the pure waters around him became crimson with his blood.

From Big Clear Pond we struck acrnss a ridge some two miles to Little Clear Pond, a sheet of water covering perhaps three hundred acres. This little lakelet, if I may be permitted to coin a word, is a perfect gem, laying there all alone, skirted by tall forest trees, and overlooked by the hills, its waters transparent and cold, undisturbed by a ripple, and revealing the white pebbles that glisten away down in its quiet depths. We dined on its banks, beneath a festoon of vines, that spread out among the branches 
of an ancient elm. While smoking, after our siesta, we saw a number of gray wood-rabbits hopping about, cocking up their long ears as they scented our cookery; and bounding away, when they looked upon our faces. The red squirrels chatted and chased each other up and down the trees around us, the partridges drummed on their logs, and the birds regaled us with their songs. To all this enjoyment there was one drawback-the bills of the musquitos were long, and the sting of the black fly severe. A mink came steal. ing along the margin of the lake, turning over the Hat stones, and looking for frogs, and small fish along the shore. He was worth shooting, and I gave him a shot. My hand was unsteady, or my eye-sight not clear, and all the harm I did him was to give him a terrible fright. He wont forget his narrow escape, for the ball went awfully near his head. He will have something to tell his neighbors, that will sound apochryphal in minkdom.

Having viewed this charming little sheet of water to our satisfaction, we followed what my guide termed a moose path, along the outlet, some three miles to the head of the Upper Saranac. I would not have it inferred that this path was trodden like a highway, or 
that we saw any spoor of the moose. It was made when that animal was vastly more abundant than it is now. It was, however, easily traceable; the deer and other animals travelled it, and it saved us much labor and trouble in guiding us directly to the lake below. 


\section{II I}

I HB UPPER SARANAO-A SONG ON THE WATER-A WOODMak's Notion oz this PAst, thi Prestent, and thri Future, or AMERI A.

WE struck the Upper Saranac towards sundown. Here we found a shantee of poles, for whatever hunter might stray away to that lonely region. We took possession, and having cleared away the dry branches used the year before for a bed, and having swept and garnished the floor, we supplied new boughs on which to repose, and went out to secure a supper. This, the water and the air supplied us with, for while I caught a string of trout in the stream which forms the iniet, my guide shot a brace of partridges, which Shack treed for him on a hemlock near the shantee. We supped as the sun gave his last rays, to glisten on the brow of the mountains, on the opposite side of the lake. My guide had hid away his canoe at some dis. 
tance down the lake, and started off to procure it, that we might take an early start in the morning, on a voyage down the Saranac. I sat upon a boulder on the margin of the lake. The sun had gone down, and the grayness of twilight was fast settling upon all things; the stars stole out, one after another, and were rellected from away down in the bosom of the waters. The evening was perfectly calm. The lake lay like a mirror before me. The leaves stood still on the trees, and all nature seemed sinking into stillness and repose. Anon, the voice of my guide rung out over the waters in simple song, as he paddled his light canoe homeward. How it might have sounded in a concert hall, I will not pretend to say, but it floated full, and clear, and musical over the waters that night, and to me it seemed full of sweetness and harmony. I thought if the Swedish Nightingale had been out there, on that silent lake that calm evening, giving to the still air the sweet songs of her northern home, her voice would have entranced the listener, like the seraphs' hymns, as they minister in the choirs of heaven. How I should love to hear it swelling over the still waters of the Saranac, and dying arvay in faroff echoes along its woody shores. But those old for 
ests will never hear her voice, nor their sleeplind echoes waken to its harmony. Long years hence, the sweet voice of some other songstress may float over those slumbering waters, but those old primeval trees will be gone. Broad meadows, waving grain, and rich pastures will be there, but these old forests will have been swept away. The songtress will sit on the doorsill of her own dwelling, on the margin of that beautiful lake, her kindred will be around her, and her song will be a lullaby to her little one that slum. bers upon her bosom. The wild deer, the moose, the catamount, and the panther will have disappeared, and that they ever existed there, will remain only in tradition. The iron horse will go thundering among those sequestered valleys, dragging his ponderous train, and snorting in the greatness of his strength.

As we sat on that moss-covered boulder, watching the fire-flies flashing their tiny torches as they floated over the lake, dotting the shadows of night with spots of brightness,-gone almost as soon as seen, my guide, in his quiet way, began one of his curious but modest discourses, to which it was always a pleasant thing to listen:. "I've often thought," said he, "how strange it was that this great country of America, equal as 
I've been told to one quarter of the earth, and may be more, should have lain here all alone for so many hun. . dreds and thousands of years, and the people of the great world know nothing about it. I say the people of the great world, for I don't reckon the Ingens as people. There were many, very many tribes scattered all over, having their own hunting grounds, and livin' in the woods; but they were wild like other animals, and savage as any other beasts of prey. They couldn't be called people, because, tho' may be they were human, yet they were wild men and women of the woods, having no knowledge of human ways, and no notion of improvin.' They hunted as the painter . and the wolf hunts, only to supply nater, and while they lived together in tribes,-in that they did no more than the wolves do,-they lived in huts, and so did the beaver. I've often thought I'd like to have seen this great country, when it was all wild and nateral like; when from the shores of the old Bay State to the Mississippi, and from the cold north, away down to the Gulf of Mexico, the old forest stretched away, and in all this, not one civilized man could be found,--before any axe had-broken the stillness of the woods,-when no city or town, church or 
farın-house, or green field could be seen; with the great rivers windin', like gigantic serpents, along the deep valleys, and the wooded plains, upon whose majestic waters no ships spread their white sails, or or steamboats puffed their smoke. I've hearn tell of the great prairies, that stretch away from the Mississippi to the foot of the Rocky Mountains, that lay spread out there, like great a meadow, thousands of miles around 'em, without a fence or a road crossin' them. Squire, 'twould have been a sight to see those vast wastes, before the foot of the white man had crossed the great Father of Waters, as I've hearn it called, all covered with tall grass, wavin' like an ocean of grain, and reaching out, away and away, hundreds of miles beyond where the eagle, in his highest flight, could see. I should like to have.seen those vast droves of buffalo, fightin', and bellowin', and pursuin', and hustlin' each other, spreadin' out all over the plain like a mighty army of horned beasts; and then, when some terror seized the herd, how the earth must have shook beneath the thumderin' hoofs of their flying hosts. I should like to have been the first white man that looked upon such a gigantic wilderness as this country then was, - to have come up 
the Hudson from its mouth, awny down by the sea,-to have floated upon its waters, as they rolled then so solitary through the Highlands, and seen the painters and catamounts watchin' me from the cliffs, and the deer starin' at me from the level shore,-to have paddled up old Champlain and down the great St. Lawrence, and then to have skirted old Ontario, away up to where Niagara pours its mighty flood, thunderin' and shakin' the earth, as it rushes down from the beetling cliffs, - to have coasted Lake Erie, and the other great seas that lay away out west,- - to have crossed over to the Mississippi, and floated on its broad bosom back to the ocean! That would have been a trip, Squire, worth a lifetime, and a thing for a man to tell his children of, of a winter's night, when he was old. I've often thought I'd like to leave the settlements and highways of life, even now, and stray away off among the solitudes of the Rocky Mountains, and the vast regions beyond them, and spend a few years beyond the footprints of a white man. I'd like to trap the beavers, and skrimmage with the grizzly bears, and hunt the elk, and foller the other sports that belong to such a wild and far-off region. Old Pete Meigs and I often talked of such a trip,-but the 
old maan had the weight of too many years on his shoulders, and I loved my wife and children too well to allow of our taking it. You and I, Squire, shan't see it, but this country is spreadin' and spreadin' out, and the time will soon be, when a man can go in a fortnight from the Bay State to the great ocean of the West, crossin' the great prairies, and dashing over the Rocky Mountains, down into the broad valleys beyond them, where will be found great cities, rich farms, and millions of people."

"Why," said I, "Tucker, you're getting poetical. You've furnished a theme for thought which we had better jinprove upon our bed of boughs in the shantee."

In the morning we started down the Upper Saranac. $T$ is lake is the largest in all this region, being some fourteen or fifteen miles in length, by from one to three in breadth. In speaking of distances I do not profess to be precisely correct; I give the best of my judgment only, and I have not myself the most perfect confidence in its accuracy. I am not, therefure, to be held responsible for any mistakes that may occur in my measurements. I judge of the size of the lakes by my eye, and of the distance from each other, by the time it took us to travel it. These are 


\section{A Dog's TRAINING.}

all my means of knowledge on the subject, and those who may come after me, must take the risk of my being mistaken.

About half of a mile or more from the head of the lake is an island, containing, I should judge, about one hunäred and fifty acres. It was covered with trees and underbrush, like the forest on the main land. We landed on this island, and found no diff. culty in procuring fish for breakfast.

"Now, Squire, I'll show you one of the knowing ways of Shack," said my guide, "and some good sport into the bargain. I educated that dog myself, for the woods, and so long as he's with me, he ain't to be beat. You see he don't start off, after everything he sees, as a green one would do, and as he did, when I first took bim with me into the woods to larn him his A B C's. He travels along with us, steady and regular as we go ourselves, doin' what he's bid, and no more. He listens to what we say, and I'm blamed it' I don't believe he's a notion of the meanin' of my huntin' stories, when I tell 'em to you. He's an example of what trainin' from a kind master, will make of an honest dog, and what improvement the animal can attain to." He called his dog, and going a few 
rods to an elevated spot, waved his hand to him, and cried, "Hunt 'em up! hunt 'em up! Be off, sir." Shack seemed to understand him perfectly, and away he dashed, coursing here and there, further and further off, until we lost sight and sound of him in the woods. In a short time we heard the bark of Shack in pursuit of something, and in five minutes a buck came dash. ing round the end of the island where we were, horribly frightened, with Shack a few rods behind him, yelping sharp and fierce, at every bound. We did not choose to spoil the sport by the use of our rifle, so we cheered on the dog, as he sped by us, and around they went again like coursers. The island was not large enough to allow the dog to get out of hearing, and it was truly an exciting thing, to hear his fierce sharp cry, and trace by the sound, the rapidity of the chase. I have stated before, that Shack was not so staunch and persevering a follower, as a dog of purer breed would have been, but so long as he would follow, his pace was tremendous, and the game before him always had an exceedingly busy time of it. Round they came again, that deer and Shack, the former more frightened, and the latter more fierce, if possible. The deer had gained a trifle of his pursuer, but the 
pace was evidently telling upon him. His tongue was out, and we heard his panting as he passed us. There was no speed lost by lofty bounding, as we often see in the deer, as he dashes through the forest; no looking back over his shoulder, and waiving his white flag in defiance, as if glorying in the speed of his flight. But his nose pointed straight out one way, and his tail the other, as he stretched himself like a race-horse, in long low bounds, every muscle strained to escape. Again we cheered on the dog, and away they went in another heat round the island. Shortly after the cry of Shack rounded the lower end of the island, we saw the deer plunge into the water, and strike out for the main land. Shack, too, plunged after him in pursuit, but the 'buck was greatly his superior in swimming, and he soon gave over and returned to the island. We might easily have overtaken the deer with our canoe, but we had no occasion for venison, and we let him go. We watched him as he swam manfully for the shore, leaving a long wake in the still water behind him. I saw him through my glass as he waded slowly to the land and steal quictly into the woods, seemingly wearied enough, but rejoic ing in his escape. 


\section{XIV.}

a sportina Excursion.-A Formet Chash-Thi Musio of tha Hounds.-This Man who Killed the Panther and this bia Вणск.

We rigged a bush sail and started before a light breeze, for another and larger island two or three miles distant.

"The way old Pete Meigs and I came to be acquainted," said my guide, as we floated down the lake, "or rather the reason why he took me to his feelins, was this :-A great many years ago, two gentlemen came from York city to Plattsburgh, to go over to the Shazee, to fish and hunt. I was about eighteen years old then, but I'd grown up by the side of the old man, and though I was a tough specimen for my age, he seemed to think I was a child still. It warn't then as it is now. The clearins had'nt pushed Dack the woods, as they've since done, and the State 
had'nt built stone houses away up here, to keep bad men in, from doin' mischief. The place where Clinton Prison stands, was ten good miles outside of a fence, and a man had to travel fifteen long ones, out'side of a road or clearin', to get to the Shazee. Those men from the city, were green enough in our forest ways, but they wanted to learn, and had the real grit in 'em, too, only it wanted bringin' out. They'd been raised in the city, in a human way, and without bein' spoiled, and did'nt calculate they know'd more, and were better'n everybody else. I was down at Platts- . burgh when they came there, and hearin' them talkin' about a guide, I told 'em of old Pete Meigs. I knew the old man was home, for I talked with him on my way, in the morning. They got a team, and I went with them to old Pete's, and we struck a bar. gain, he to go with 'em as a guide, and I as a kind of pack-horse, to carry the provisions, and the other things needful. I did'nt take my rifle that trip, for the Yorkers being unused to travelin' in the woods, old Pete and I, had to tote the fixins. Next morning bright and early, we started for the Shazee. We had fifteen long miles afore us, without a path, over high hills and down into the deep valleys, crossin' the 
strearns, and stumbling among the tangle brush and boulders. If the Yorkers war'nt tired enough when we got to the lake, you may shoot me. We'd been all day about that job, and the sight of the waters laying there so bright and still, was a pleasant thing to their eyes. We did'nt mind it much, because we were used to it. With us, a day's work was a day's work, whether in the woods or in the fields. Old Pete and I put up a shantee for the Yorkers, and made them a nice bed of boughs with a smudge before it, to keep off the musquitos and black flies; we left them sleeping sound enough, and started to procure a mess of trout for supper.

"The old man had drawn his canoe away out of the water, a month or two before, and hid it away among the brush. From some accident,-may be the lightning, the woods had got on fire, and instead of his canoe, we found only a few charred and useless chunks. May be the old man didn't swear some, but t'want no use. The canoe was clean spoilt, and any amount of swearin' wouldn't mend it. It only cost us a hard day's work to make another, which, by the way, we had finished on the next day but one. But for all the loss of the canoe, we did'nt go without our 
supper; for standin' on the rocks, we got trout enough in a few minutes; and when the gentlemen woke up, we had 'em ready cooked after the ways of a hunter. The way them trout disappeared from before the Yorkers, was a sight to see. Old Pete had two of the finest deer hounds I ever happened to see,-especially an old one that the old man called Roarer. He was a great tan-colored animal, with a broad chest, and a mouth like an oven, with great loose lips hangin' down from his jaws, and ears like an elephant's. His voice was like a trumpet, and the way he'd make the woods ring with his music, was a pleasant thing to hear. These dogs he had taken with him, to show the gentlemen what sport was in the Shatagee country.

"The next morning we were up by the dawn.

- Our Yorkers were fresh and fierce for the sights and fun of the woods. Everything around was new to 'em. The thousand voices that one hears in the forest, were things for them to admire and talk about. We concluded to have a chase the first thing in the morning, not to run the deer into the lake, for our canoe was gone, and we couldn't catch 'em there; so we started to drive the ridges, as we call it. The old 
man knew the woods like a book, and could always tell by the make of a country, where away a deer would run, when pressed by the dogs. Now, Squire, a deer has ways of his own, which a man who has lived among 'em and hunted 'em, can understand. When pressed, he will take to a ridge, and follow it till he's tired, and then he'll take to the water if he can, to throw off the dogs.

"Well, before the sun was up, we started out back of the lake, and old Pete stationed the Yorkers some forty rods apart, on a low ridge that stretched away from the lake, far into the woods, at a spot where he knew the deer would be most likely to pass. Having placed them to suit him, he lent me his rifle, and took me, may be a quarter of a mile beyond, and placing me near a great oak at the head of a broad, shallow ravine, left me to lay on the dogs. He hadn't no great notion then of my merits, as a hunter, or as a marksman, and I've allers believed he placed me there, more to get me out of the way, and keepin' me from spoilin' sport for the Yorkers, than anything else, for from what I've learned of the ways of the animal and the woods since, there warn't much danger of a deer's comin' near me. 'Now,' said he, 'Joo 
understand, we're here arter deer, and not arter partridges or squirrels, and you're not to spoil sport by shootin' anything short of a painter or a big buck;' and the old man grinned, as he started off with his hounds.

" He hadn't been out of sight long, and I'd seen 'twas all right with the rifle, when I heard a scratchin' like among the branches of the great oak, six or eight rods from which I was standing. Looking over that way, Squire, I'm blamed if I didn't see, laying stretched out along one of the great branches that put out towards me from the trunk of that old oak, may be thirty feet from the ground, a great painter, lookin' with most villainous fierceness straight at me. That was the first of these varmints that I'd ever seen alive in the woods, and the way I kind a crept all over. warn't pleasant. I was standin' by the side of a maple which was partly between me and the animal, and I warn't sorry it was so. I don't know as the painter meant me any harm. It's very likely he'd made up his mind to let me alone, if I'd let him alone; but I didn't like the way he eyed me. I drew up old Pete's rifle by the side of the tree, and my hand shook some as I sighted at his head. I wasn't fool enough to fire 
till my hand was steady, for I knew if I was calm, I could put a ball between his eyes from where I stood, and no mistake. I sighted him close and steady at last, and pulled. The painter leaped straight towards, and fell a few yards from me, dead, with his skull shattered by my ball. 'There,' said I to myself, as I fell to reloading my rifle, 'old Pete didn't think when he told me to fire only at a painter, or a big buck, that, that cussed critter was about.' I was a big feelin' man then, Squire, and about the proudest one in the Shatagee country.

"I was examinin' the beast, when I heard far off in the woods, the voice of old Roarer, deep and drawn-out-like at first; after a moment I heard it again. The time between his baying became shorter and shorter, till the dogs both broke out in a fierce continuous cry, and I knew the game was up and away. I needn't tell you, Squire, of the music there is in the voice of a pair of stag hounds, in the deep forests of a still morning. How it echoes among the mountains, and sweils over the quiet lake; how it comes up like a trumpet from the forest dells, and glancin' away upward, seems to fill the whole arr with its joyous notes. The dogs took a turn away to the 
westward. The sound of the chase grew fainter and fainter, as it receded, until it was lost to the ear in the distance, and the low voice of the morning breeze whisperin' among the forest leaves, alone was heard. After a few minutes, I heard, faint and far off, the music of the chase again, swellin' up in the distance, and then dyin' away like the sound of a flute in the distance, when the night air is still. Louder and more distinct it came, as the dogs coursed over a distant ridge: I stood, as I said, at the head of a shallow but broad ravine, or rather valley; to the right and left, the ridge stretched away like a horse-shoe, leavin' within its curve a densely-wooded hollow. I heard the hounds as they crossed this ridge far below me, loud and joyous, makin' the woods vocal with the melody of their voices. Again the music died away, as they plunged into the hollow way before me, until it seemed to come up like the faint voice of an echo, from that leafy dell. Again it swelled louder, and fiercer, as the chase changin' its direction swept up the valley. Louder and louder grew the music; I heard the measured bounds of a deer, as he dashed up the ridge on which I stood, some forty rods from me, and wheelin' suddenly from the direction in which he was 
goin', an enormous buck broke, with the speed of a race-horse from the thicket of underbrush that had concealed him, directly towards where I was standin'. I was ready, and as he came withir a few rods of me, I fired. He leaped high into the air, and fell to the ground. My huntin' knife was soon passed across his throat, and his struggles were over. It was a noble buck. I have been a hunter ever since, and I have seen few larger than the one I shot that morning.

"In the meantime, the dogs swept by me in full cry towards where the Yorkers were stationed. It seemed that two deer had been started by the hounds, and had ran together, until they struck the ridge on which I stood, when one had turned suddenly from his course, and the other fled forward. I heard two shots in quick succession. In a few minutes the music of the dogs ceased, and I knew the chase was over. I passed down to the Yorkers, and found them rejoicin' over a fine doe they had slain. Both had fired upon her--the one woundin', and the other killin' her. They supposed she had passed me, and took it for granted I had missed her. Old Pete came in. He had heard my first shot, and supposed of course, I had been firin' at some triflin' game. The old man 



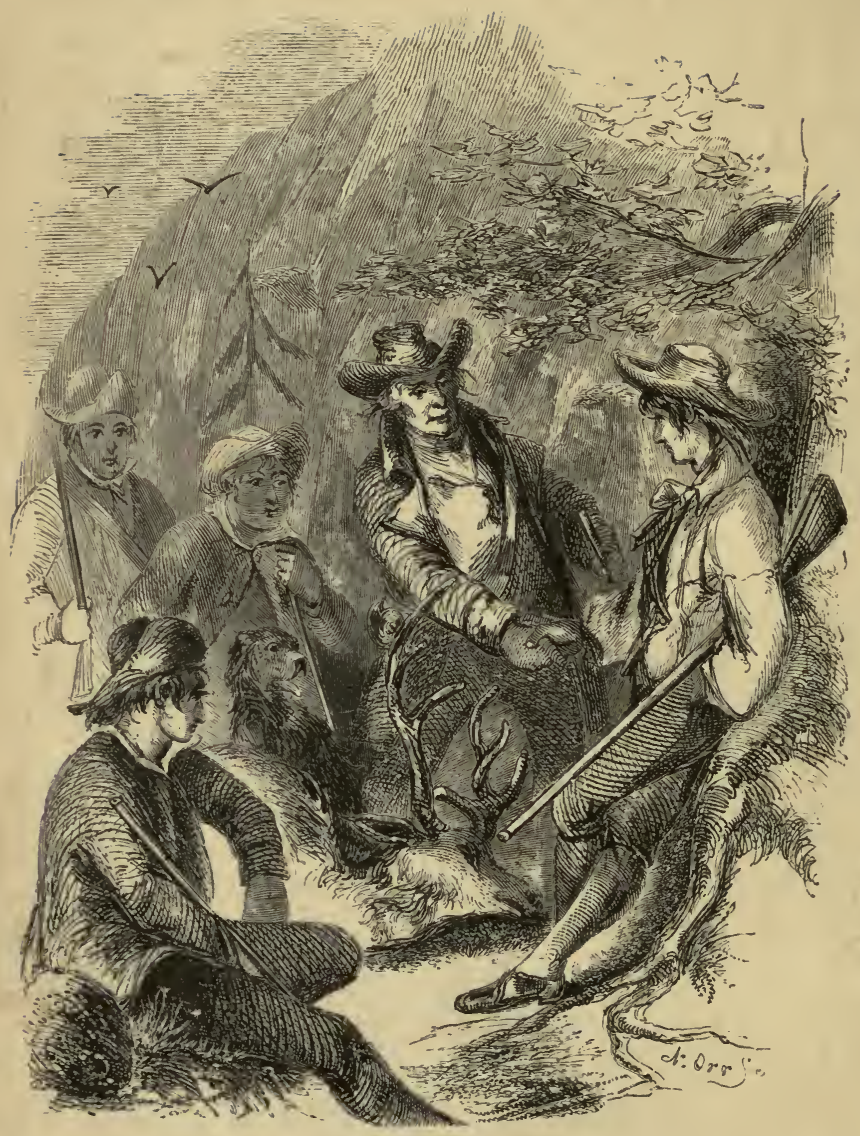

JOE, SAID HE AS HE HELD CIUT HIS HAND, SKIN ME IF YUU UAVENT DONE IT. Page 145. 
joined the Yorkers, in laughing at me. 'Come,' s.id I, as I took him by the arm, 'go with me, and I'll show you what a hunter can do.' We went up to where the buck lay, and you ought to have seen the nld man's eyes open, as he rolled him over. 'Joe,' said he, as he held out his hand, 'skin me, if you haven't done it. I've been after that buck for two years. Why, he's the old one of the Shatagee.' I led him to where lay the painter, 'There,' said I, 'you told me to kill a painter, and a big buck, and I've done it.' The old man threw his arms around me, and from that time, I was to him as a son. Many and many's the time I've hearn him tell that story, and been pointed out by him as the man that shot the painter and the big buck." 


\section{V .}

Totjog Yarns - A ShHLter JN a Storm. -AN agtonishri Beak-

AN UNINVITRD GURST, AND BIS UNOHRMONIOUS EXPULBIO:

"Tucker," said I, as he finished his story, "it's my opinion you sometimes shoot with something besides a rifle,-what we call, in the city, a long bow."

"Squire," he replied, "I won't pretend not to take your meanin', nor find fault with you for expressin' it; bui what I tell you I've seen, and done myself, you may set down as a sure and certain thing. I don't deny, that down in the settlements, among fellers that think themselves tall timber, I stretch matters a little, and make things look a good deal bigger than the real facts will warrant. I've told 'em about killin' a buck that weighed four hundred, that had, may be, fifteen or twenty prongs to a horn: but that was always by way of taking the starch out of fellers that pretended to krow the ways of the woods, 
and lied out of whole cloth. Let me tell you, Squire, twenty odd year in the Shatagee country, and among the Adirondacks, brings a man acquainted with a good many curious facts to talk about, and he needn't tell anything but the simple truth, to get up a pretty tall name for shootin', as you say, with something besides a rifle. Between old Pete Meigs and I, we never stretched the honest truth. Any man that went with him into the woods, might be sure that, strange as the story might be the old man told, it was gospel truth. He was proud of his knowledge of the ways of wild animals, and the things he'd seen in the woods, and he was principled agin deceivin "the man that trusted him. No man ever came back, after a tramp with him in the forest, that wasn't wiser, and that in solid . truths, than when he started. But in the settlements, it was another thing. He didn't mind drawing a long bow there, by way of stuffing the green ones, and the way he did it was a thing to laugh at.

"I mind once we was down to Plattsburgh, and stayed all night at a tavern there. In the evenin' some fellows came in, that had been over to the Shazee. They'd done pretty well, considerin' they didn't know much about wooderaft, and the stories 
they told were amazin'. They made a set at the old man, to draw him out. It warn't very difficult to start him, and the way he went ahead was surprisin'. Knowing the old man's truthfulness in the woods, it was a new thing to hear him tell such whopping lies about fishin' and huntin', but a sly wink told me they wan't meant for me, and I knew it was all right, but such stories, Squire, I never happened to hear before. 1 mind one he told, by way of a wind up, was this: 'I was,' said the old man, 'four years ago, away up among the Saranacs, and had strayed away four or five miles from my shantee, when there came on the orfullest storm of rain, and wind, and thunder and lightnin' that ever mortal man heard tell on,-you - ought to have been up there, boys, to have hearn the thunder boomin' and roarin' through the heavens, and peelin' and echoin', and knockin' about among the Adirondacks,- - to have seen the lightnin' flashin' and flamin' along the ground, and dartin' down from the clouds into the tall trees, and smashin' them into a thousand splinters,- - to've hearn the timber crashin' and thunderin' to the ground, as if all nater was goin' to ruin in one universal smash. Well, if I warn't scared that time, you may shoot me. So, lookin' 


\section{THE STORM.}

across a low swampy piece of ground, I saw the great holler trunk of a sickamore that had fallen, and I put across, thinkin' I could crawl in there, and be safe from the rain and fallin' timber. As I struggled through the swamp, I sunk knee deep into a kind of clay, white as paint, and my boots were plastered by it, as if I'd run my legs into a tub of batter. I crawled away into the log, and let me tell you, boys, it warn't a bad place to be in just then. I lay there snug enough for about half an hour, the storm ragin' all the time harder'n harder, and as I heard it roarin' and surgin' around me, I made up my mind that a holler log was a good place in sich a storm. All at once the hole I came in at was darkened, and something came gruntin' and squeezin' in towards where I lay. "Human nater !" tho't I, "what's that?" After a little, I saw by the light that streamed in, in little streaks by him, that 'twas a huge bear. I wasn't scared, for I knew he didn't know I was there, and besides, a bear allers goes into a holler -log backwards, so that the end he bites with wasn' towards me. I didn't care about havin' a fight with him just then, and if I killed him in the $\log$, I didn't exactly see how I was to get out by him. So I drew up my legs, as he came backin' 
up towards me, and when he got about near enough, I straitened out; and the way I sent my boots agin his back settlements, was a thing to wonder at. If ever a dum animal was astonished, I reckon it was that bear; and the way he put for daylight, was curious. As he grunted and hustled towards the outside of the log, I followed on my elbers and rump, and the kicks I gave him in the stern, shot him like a cannon ball, about twenty feet down the banks. "There," said I, "you darned black, stern goin', round about circum. stance, be off to your own hulm, and let honest people's houses alone." He didn't stop to make any answer, nor to ask any questions, but put out at his best gait for the Shatagee, and it's my opinion he never know'd what it was that booted him out of that holler log. He was done with the Saranac lakes, for he was shot the next day, forty miles away down by the Lower Shatagee. I know it was the same bear, for there was the white prints of my clayey boots on his rump. plain as a pike staff. If you don't believe it, you may ask Joe Tucker there, (pointin' to me,) for he's the man that shot him.' I didn't, of course, con. tradict the story, and the fellers standin around, took it all for gospel. But many's the time I've quizzed 
old Pete Meigs about the bear, whose rump he painted with his boots, in the holler log."

Our course kept us but a few rods from the shore. and we could look into the little bays and inlets as we passed along. There are many lovely spots along the coast of the Upper Saranac, which, had we not, seen many others in our forest route as lovely, would have claimed a more careful survey. The beauty of the scenery around these lakes, to be appreciated. must be seen. More than that, it must be seen bv those who have a taste for the woods-who love to be sometimes alone, beyond the hum of the thousand voices, that are heard in the thoroughfares of lifethe tramp, tramp of moving thousands-to be awav. among nature's unshorn, as well as unadorned loveliness; to hear her, unawed by the sights and sounds of civilization, talking (as my guide termed it) to herself. They must be men of patience and some nerve, who are, for the sake of the pleasure, willing to submit to some privation, to encounter some weariness, and much discomfort. The student, whose frame is enervated, by the corrupted and heated atmosphere of a city, and the debilitating influences of his vocation, will find himself growing stronger, his frame more 
vigorous, his step lighter every day, that he breathes the fresh pure air of the lakes and mountains. Every drop of sweat, forced from his pores by the weariness of travel in the woods, will carry off some particle of disease. He will sleep calmly, and sweetly, on his bed of boughs at night, and rise in the morning, full of freshness and strength. His food will be pleasant, and his digestion good. He will be astonished at the increase of his powers of consumption, and after a few weeks of hard work, but full of enjoyment in the woods, he will come out a better and a wiser man, with renewea vigor, and a longer lease . 'ife. 


\section{VI.}

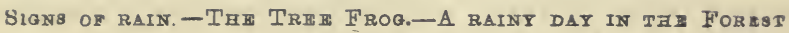

The breeze had now floated us to the secund island. We shot into a little bay, and remained for a short time, admiring the scenery around us. "Squire," said my guide, as we lay in this little bay, enjoying its cool shades, "it always seems to me that a man thinks more and better away off in the woods, among the wild kritters and nateral things, than he does in the settlements or in the towns. That he comes to be what you call a philosopher-'a sort of nateral poet-and though he mayn't write verse or string rhymes, yet there's real poetry in his heart and in his feelins'. He sees things that sets him a reflectin', and makes him inquire into their nater, and it's thinkin', and inquirin', that makes people wise. Experience is a great thing everywhere, but a man won't $7 *$ 
improve much, if he don't look into the reason of things that he sees around him. Anybody, out here in the woods, when he builds his shantee, would cover it with bark so as to shed rain, if he saw a black cloud in the south-west, and saw the lightnin' playin' around its edges; but it takes a 'cute observer to look into a cloudless sky, and say it will rain afore morning, or it will be a wet day to-morrow, and have his sayin' come out true.

"You, now, though you may be a smart lawyer at home, don't know that we shall want a shelter afore mornin', and won't leave it until noon to-morrow, unless we agree to be out in the rain-but I know it, and if you wan't to know how I know it, I'll tell you. Just listen to the tree-frog, how merrily he pipes all along the shore, up amiong the branches of the scrubby trees that grow out of the rocks; well, he says, 'it'll rain.' Listen again to the loon-hear, with what a loud, clear voice he speaks, and how it quavers and sinks away into silence; you havn't heard that voice since we left Indian Lake. That loon says, 'it will rain.' Hark again, and you'll hear not a rustling among the leaves and branches of the trees, but a kind of deep far-off moaning; not the creaking of one tall trec 
against another-a sour.d that don't seem exactly to be a sound either-a sound that we seem to hear but can't describe; you can't tell what way it comes from, whether from the right hand or left, that seems to be far off, and yet you can't say it isn't close by ; yet it's in the forest, all around you. Well.' that mysterious voice says, 'it will rain.' Look at that brood of young ducks, scampering about, dipping their heads under the water, and lettin' it run down their backs-see the old one, how often she sits up on eend, and flaps her wings, as if about flyin' away-those ducks are sayin', plain as day, 'it will rain.' Look at that baswood tree on the point before you-see how fan-like it lifts its leaves, turnin' their under side to the sun, makin' the tree-top shine all over like silver; that tree is tellin' us 'it will rain.' Even Shack, there, in the bow of the canoe, by his uneasy motions, curling himself up in a heap at, the bottom, and then as soon as he's fairly settled, gettin' onto his feet again, and nosin' out over the water, he says 'it'll rain.'

"Now, Squire, it's by observin' and puttin' things together that a woodman comes to understand such matters. I don't consider such knowledge any great things, but it shows that all the larnin' in the world 
ain't found in books and isn't got in the colleges. A greenhorn would be just as likely to hunt with the wind, as against it, and wonder why he didn't get sight of a deer. I could tell him why; it's because a deer can smell a man twenty, and may be forty rod when he hunts with the wind, and will get out of his way; while he who hunts agin the wind, the deer won't smell him at all, and he knocks him over. You see how suddenly that brood of young ducks have disappeared. Well, a man not used to their ways would say, they hid away because they saw us; but when I see that, I look round for a bald eagle, and he's sure to be soarin', like that one yonder, in the sky. These things; as I said, ain't much of them. selves; but it's such small things that set men to thinkin', and studyin', and at last roils up into a heap of knowledge. It may be, it wouldn't be worth much to trade on, in the cities; but it's a good thing out '2ere in the Shatagee, and don't hurt a man anywhere. l've hearn it said, that a great many years ago, a Inan was 'restin' himself under the shade of an apple tree, when one of the apples fell to the.ground, that it set him to thinkin' why it should fall down to the ground, instead of upwards, towards the sky; and that 
by thinkin', and observin', and studyin', he built up a great system of philosophy that has ever since been taught in the schools, and given to the world a deal of knowledge it didn't possess before. It's thinkin' and studyin' and observin,' that made the steam engine, and the telegraph, and the locomotive, and railroads, and steamboats, and the spinin' machines, and iron ploughs, and many other useful contrivances, that belong to the times we live in. These things don't concern me much, for my ways ain't like the ways of most men. I love the woods better'n the settlements or the cities. I don't need but little to live on, and I don't want to be rich; but they help the world along amazin'ly, and I like to see it. The Shatagee Woods will last as long as I shall, and I shall stay among 'em; but people that don't like the woods, they help to a livin', and if they want to go ahead, they can go.

"I mind once, I was over on the Lower Shatagee, with a man from Montreal. He wasn't a hunter, nor much given to fishin'; but he'd a likin' for the woods, and I paddled him round the lake for a week. He went knockin' the stones to pieces, and lookin' into the nater of all the rocks about, and studyin' the 
flowers, and pressin' them between the leaves of a great book. He didn't care much about the deer, but he cracked away with his double barrel, at every wood-bird he could find. When he got what he called a specimen, he took off the skin, and stowed it away, as he said, to be stuffed when he got home. Well, what I was goin' to tell you is, we was out one day on the lake; it was warm, and the sun shone down clear, and bright, and hardly a breath of air was stirrin'. On our return to the shantee at noon, he looked at a machine he had hung up against the poles, and says he, 'Friend Tucker, there's rain a brewin', and you'd better mend the roof of your wigwam.' I hadn't noticed the signs, and how he came to know there was going to be a storm, beat me. Well, I went out, and looked about me, and listened, and sure envugh, there was no mistakin' the appear. ance of things. Now the machine he looked at, told him as plain as A B C, what weather was ahead. It's name I disremember, but you, may be, know all about it. - I allers thought it took a good deal of studyin' and lookin' into the nater of things, to invent a ma. chine to foretell a storm."

We shot out from the little bay, and paddled on 
sapp -1y a light, pleasant breeze was blowing down the lake, and holding a bush, with the butt end on the bottom of the boat, so that the breeze would strike it, was my part of the labor. In the afternoon a haze gathered in the air; a veil, of thinnest gauze, seemed to be drawn over the heavens; a halo surrounded the sun; the tree-frog sang louder than ever; the ducklings sported more joyously, and all the signs spoken of by my guide, became more strikingly manifest. We landed, between four and five o'clock, on the third island, and set about constructing a shanty, which would afford shelter from the rain, which it was now certain would visit us. We selected a site by the trunk of a large tree that had fallen. Having procured two forked saplings, of some three inches in diameter, we fastened them securely in the ground, about ten feet from the log, and eight feet from each other. Across these, in the crotches, we laid a pole, some five feet from the ground, and then placed another, from each crotch to the log, for rafters; across these again, at a distance of two feet from each other, we laid other poles. My guide peeled bark from the birch trees áround us, with which we made a roof, as impervious to the rain, as one of tiles. The ends we 
built up with boughs, to keep off the lateral dampness. Behind the log, we scooped out a rude trench, to carry off the water that should drip from the eaves of our dwelling; thus, in twc hours, we had constructed a secure shelter from the rain, let it come when it might. We gathered large quantities of hemlock and spruce boughs for bedding, and prepared wood to keep alive our fire. This was necessary, not for warmth, but to keep the musquitos and black flies from devouring us.

Having finished our shantee, my guide, with Shack at his heels, started towards the interior of the island. This is the largest island of the Upper Saranac. I soon heard him ordering Shack to "hunt 'em up," as I have described. He returned, and we paddled quietly down the lake, to a point fifty rods below, where a low ridge terminated in a point, some distance from the line of the shore. Here we shot close under the bank, beneath the branches of a gnarled birch, that grew out almost horizontally from the rocks. It was half a mile to the main land from where we lay, and it was the narrowest part of the channel which divides the island from it.

We had lain here but a few minutes, when we 
heard the bark of Shack, and presently a deer went crashing through the underwood, a short distance from us, with Shack in close and hot pursuit. Round the island they swept, and we lost the cry of the dog in the distance. In the course of fifteen minutes, we heard him again on his return. We heard the deer dashing through the brush, with Shack a few rods behind him. The deer passed us like the wind, and at the point behind which we lay, plunged into the lake. We wanted that deer, and giving him a few rods start, we shot out in pursuit. Before leaving our shantee, my guide had cut a long slim pole, like a fishing rod, and withing the end, formed a running noose, large enough to throw over the head of a deer; and threw it into the canoe, as we dashed from the shore. I have before described a chase after a deer in the water, and will not repeat the description here. This time, however, we were in earnest. As we approached the game, my guide threw the noose of the withe over the animal's head, and pulled him, struggling desperately within reach, drew his hunting knife across his throat, and in a few minutes his struggles were over. We hauled him into the canoe, and paddled back. We found Shack sitting on his 
haunches, watching us calmly from the point, and he trotted gaily along the bank, as we floated to our landing-place by our shantee.

The evening was close and dark, save when the millions of fire-flies flashed their little torches over the water. The tree-frogs quavered vociferously all around us, and the old owl hooted mournfully from his perch in the dense foliage, as we lay down to sleep. About two o'clock in the morning I awoke, and the rain was pattering steadily on the roof of our shantee, and dripping in big drops from the leaves of the trees. It was a soothing and pleasant sound, the steady falling of the rain on our shantee, and among the dead leaves. The tree-frog had ceased his music, and all the wild forest notes were hushed. I glided sway into slumber again, and slept an hour later in ihe morning, than I had done before, since I entered we woods. My guide was up when I awoke, and busy preparing breakfast. He had, while I slept, caught some fine trout, which, with a venison steak, he was broiling on the coals. The rain was still falling steadily, -the clouds were sweeping low, and wet and heavy above us before a steady but slight southern breeze, and all around us betokened a wet, unpleasant day. 


\section{VII.}

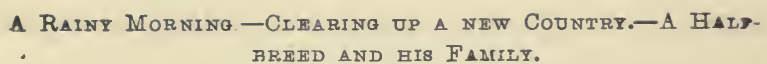

WE sat after breakfast, in the morning, under the shelter of our homely roof, smoking our pipes, and listening to the small rain pattering upon our covering of bark, and the big drops rustling among the forest leaves. "A rainy day isn't a bad thing, Squire, for you and I here," said Tucker. "It gives us a resting spell, and shows us the forest in a new dress. We've worked pretty hard since we started, and want a little breathing time. To me it ain't much, for I'm used to it, and a few days travel I don't mind; but you've been raised in a city, where people ain't used to such jaunts as this, and their timbers won't stand, at first, what mine will. You've stood it bravely, and I'll own up, that when we started, I thought I'd stretch your legs for you, in a way that would make you give 
in ; but I havn't done it, and I ain't sure that I can do it now. You seem to have a nateral way for the woods, that ain't common for the city people."

"Why," said I, "Tucker, though I live in the city, and have done so for eight years, yet I was raised in the woods, and brought up in a region almost as wild as your own Shatagee. I remember the time when I could be sure of a deer in half an hour, from the time I left my father's door. I have caught many a one in a lake with a canoe, as we caught that one last nigitt, and have, hundreds of times, listened to the music of my own hounds on the mountains. Bears and panthers I knew nothing about, because they did not frequent that part of the country. I remember when about the Crooked Lake, in old Steuben, was a dense wilderness, as it is about the Lower Shatagee now, and my father's log house and clearing, was the only one for fifteen miles along its shore,-when we had to go eight miles for a doctor, and seven miles to a mill. If we wanted to see a neighbor, we had to travel three miles to do it, and my father's house stood at the end of the road. I am younger than you are, Tucker, and when I left that country, eight years ago, it took a pretty tough, long-legged man, to tire me out 
in the woods. It's a rich farming region now, and railroads, and plank roads, and turnpikes, cross each other every few miles."

"Give me your hand, Squire," be replied; "I didn't mean to ask your history, but I'm blamed if I havn't tho't all along, that you knowed more about the woods and wild things than can be learned in a city. I don't wonder that you want to get back, once in a while, to your old friends, the trees, the lakes, and the streams, and hear the voices of the things that you heard in your young days. It makes a man young again, and brings back the old thoughts and affections of his boyhood. How curious it is to watch the growth of a country that's young and wild. I ain't talkin' now about the nations, nor governments; I don't pretend to know anything about what larned people call the wealth of nations; I ain't speakin' about the growth of commerce, or the spread of trade, or the increase of manufactered things; but I mean a new country, where the woods stretch out every way, and are occupied only by wild animals, and may be, now and then, by a stray hunter, like old Pete Meigs and me.

"Some bold-hearted Yankee marches into the 
woods, with his axe on one shoulder, and his rifle on the other, and falls to choppin' down the great trees. Presently there's a spot in the forest that the sun shines down on, bright and clear. The logs and brush are burnt up, and a field of grain waves in the summer winds. After a little, you'll see a log-house, and a woman sittin' on the door-sill, with a brood of hardy, tough little ones, tumblin' about her. You'll hear the blows of an axe, as the settler battles with the tall forest trees, and you'll hear them through the day, crashin' and thunderin' to the ground. You'll hear the bark of a house dog, - the cacklin' of fowls, and the quackin' of ducks and geese. You'll hear the ding-dong of a cowbell in the woods, and the tinklin' of a sheepbell along the fences. These are new sounds in the forest, and the old woods may know by them, that their time is come. Away off, may be miles away, another hardy settler puts up his cabin, and makes war on the ancient forest trees. Year after year, the woods are crowded back by the fences, till settlement meets settlement, and the old primeval things have passed away. Painted houses have succeeded the log cabins; flocks and herds, feeding in rich pastures, are everywhere seen,-the suund of the 
woodman's axe is still,- the crash of the fallin' trees is no longer heard,- - the blazing fallows, sendin' their dense smoke curlin' and wreathin' to the clouds, are things that have ceased to be; for the old woods have been swept away. The ding-dong of the cowbells has died away, for the wearers of them no longer wander in the forest. Stage coaches are rushin' along the highways, and may be an ingine thunders along a railroad through the valleys. All these things I've seen in the Lower Shatagee country. I went out there last spring, and as I stood on the brow of a ligh hill, lookin' away off over what, when I was $3_{1}$ boy, was one great forest, from old Champlain clear away to the St. Lawrence,-I saw nothin' but great farms, and fine houses, and abundance of cattle and sheep. I - counted ten carriages on the highways in sight at once, and I saw the long line of a railroad, stretchin', like a great snake, across the country, and in ingine, dashin' like a maddened war-horse, with its long train of cars, off towards Rouse's Point.

"It's only the rocky, and barren nater of the country around us, that saves this wild region from what I call the desolation of civilization, and the mighty changes it works on the face of a sountry; 
and I'm glad it's so. There should be left, some broad sweep of wild woods, where a man can get of the sight and sounds of the clearin's, and look upon nater, as it came from the hands of the great Creator, with all the wild animals, and nateral things that belonged to it in the times of old."

About eleven o'clock, the clouds began to break away - the rain gradually ceased, and by noon, blue spots of clear sky were visible. We struck out across the lake, to a small island four or five miles distant: After resting awhile, and coursing a deer with Shack, twice round the isiand, we paddled on to the foot of the lake. Her ve hid away our canoe, and travelled across a low ridge to a small lake, the outlet of which, with those of two others, formed Stony Brook, one of the hundred streams that go to make up the upper portion of the Racket river. On the banks of this little lake, we found the hut of a half-breed, who, with his wife, and two dirty half-clad children, the oldest six and the youngest two years of age, with as many shaggy, ill-looking curs, lived a solitary life during the summer months, away off here, on the banks of these sequestered waters. As we approached the cabin, the two curs flew yelping and bariking towards 
us, but the sight of Shack's ivory, as he grinned threateningly at them, seemed to cool their courage, and they slunk away to their kennel. The woman met us at the door, gazing stupidly at us. She understood no English, while her mongrel French and Indian was equally unintelligible to us. She was certainly no beauty, nor yet remarkable for cleanliness of person, with a face and neck the color of sole leather, and hair half-combed, tied in a loose knot at .the back of her head. Her husband, if such he was, we saw in his canoe, near the opposite side of the lake. Towards sundown he returned. He spoke broken English, and we understood each other very well. We slept in his cabin that night; but let no man be guilty of so great a folly hereafter. He had a tolerably decent bed made of the feathers of ducks and other wild birds. The sheets were none of the whitest, but they were not positively dirty; and I thought it would be a luxury to sleep in a bed once more. After bathing in the clear cold waters of the lake, I undressed while the woman was out, and turned in. I felt exceedingly comfortable, and soon fell asleep. Towards morning I awoke, with hun. dreds of fleas, and bed-bugs fast hold of me, and as 8 
many more, travelling in different directions over my bar: flesh. I did not stay long in bed after that. Under pretence of some temporary ailment, I threw on my clothes, and went down to the lake, thanking Providence that enough of me was left to bathe in its pure waters. I hate a bed-bug and a flea, with un. mitigated malignity. I do not love a musquito or black fly; but they have some decency about them; they will eat their fill, and fly away and leave you. If a bed-bug or flea, would eat and lay down, I could. bear them; but after feasting upon my blood, to make a highway of my body to travel round on, is a thing I can't stand.

"Squire," said my guide, as he came down to the margin of the lake where I was sitting, and the rascal grinned when" he said it, "What started you out so early ?"

"Perdition seize the bud-begs and fleas," said I, in my wrath, at the unclean vermin.

"I've tried that bed," said he, "once, and I wasn't disposed to quarrel with you, as to who should sleep in it last night. T'm blamed if I hadn't as soon sleep on a hetchel, as between them sheets. Them cussed bed-bugs and fleas, ain't a common 
breed. They've longer teeth, and a heavier tread than is common; and they love to travel about, more'n any things of the kind, I ever happened to meet with." "Then," said I, "you are no true man, Tucker, and have not taken the care of me, that you promised you would, when we started. Why, in the name of mercy, didn't you tell me of this last night, and save me trom such an infernal crucifixion, as I have undergone ?"

. "I did think," he replied, " at one time, of tellin' you to take a club to bed with you, or to put your huntin' knife under your pillow; but you seemen to take to the idea of sleepin' in a bed so, that I thought may be you'd like it."

"Look here," said I, "Tucker, when you told me about kicking that half-breed, over at Indian Lake, I doubted the justice of the thing; but I am satisfied you di'd right. A man who can stand such an array of vermin, it won't hurt to be kicked. It would be a pleasant change, from the agony of being devoured by them, to the luxury of a booting. - Confound the half-breeds and their cabins. They cultivate a bad breed of bed-bugs and fleas." 


\section{V III.}

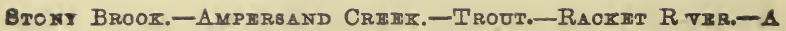
FLYING BHOT AT A BUCK.
}

OUR sea-biscuit was exhausted. The half-breed's wife baked for us a lot of heavy biscuit, and having purchased his canoe, for all which, we paid him a five dollar gold piece, which I verily believe was more money than he ever owned at any one time before, we started onward again across these lakes, towards the Raquet river. They are three in number, containing, each, some three or four square miles; con. nected by deep narrow channels, of from a few rods to half a mile in length. Near the foot of the remotest of these ponds, just above the outlet, enters a small cold stream, called "Ampersand brook," at the mouth of which, in the cold water, the trout congregate. Here we stopped for a short time, to secure a mess for dinner. We caught what we wanted in a few min. 
utes, and beautiful fish they were, weighing from a quarter to three quarters of a pound. We refrained from killing more than we needed for food, and our sport, though exciting, was therefore soon over. We left at the mouth of that little brook, an unknown number "of the same sort" as those we took, all of which seemed as eager to be taken, as we were to take them.

Having thus procured a supply of trout, we started on down Stony Brook, as the outlet of the lakes is called, towards the Raquet river. Though, in a direct line, the distance does not exceed three miles, we had to traverse, in the meandering and crooked course of this sluggish stream, more than twice that distance. In rounding a point, we saw a fine deer, feeding in a natural meadow, or little prairie, bare of timber, ánd which, in the spring freshets, is overflowed. My rifle was in the bottom of the boat, and before I could bring it to bear upon him, he had discovered us, and as he went bounding away towards the woods, I took a flying shot at him, and was glad to know that the extra speed with which he fled from us, was only the effect of the report of my rifle, and the whistling of the ball by him. At two o'clock we entered the 
Raquet, - one of the most beautiful little rivers in the world. In this mountain region, one would look for a rapid, roaring stream, - one that went cascading down steep declivities, swirling away between beetling precipices, and plunging down perpendicular ledges, in its mad course towards the great deep; but nothing would be wider of the truth. For fifteen miles above, and sume fifty below where we entered it, this river, save in a single locality, flows along with a deep and steady current,-winding around wooded points, and stretching in long reaches through an uibroken wilderness, the shores lined with forests of gigantic growth, or natural meadows.

The appearance along the shores is that of a country beautifully level, and were it not for the tall peaks standing out against the sky, dim and shadowy in the distance, and the mountain ranges looming up where a break occurs in the forest, one would think that he was in a region like the Mississippi valley, rather than hemmed in by the Adirondacks, and upon the highest land, the dividing ridge that separates the waters that flow into the Atlantic through the Hudson, from those that find their way to the majestic St. Lawrence. This Is a cold, hard region doubtless. Its winters are long, 
and it may well be for years a desolate ani solitary place, but I selected many a spot where, long years hence, would be beautiful and productive farms. Where meadows and green fields would stretch away from the river towards the hills, and where fine farmhouses and barns would be seen, and flocks and herds would be grazing in rich pastures. The interval land along this beautiful river, will one day be valuable, as it cannot fail to be productive. The average width of the river for twenty-five miles ábove Tupper's Lake, is some fifteen or twenty rods, and its banks are everywhere lined with a dense forest of gigantic lowland trees. We saw, every few rods, the paths made by the deer, as they entered or left the river, in crossing, and in the soft, tenacious clay at one spot, we saw an "old track" of the moose. Days had passed since he crossed, but there was the print of his great hoofs in the clay, and I examined it with no little interest. T'here are but few of these animals left, and they are infinitely shy and cautious. They seek the deepest recesses of the woods, the darkest shadows of the swamp, for their hiding-places, and with an eye that never sleeps, and an ear open to the softest whisper of danger, they hold their ceaseless vigils. They uave 
the keenest scent, of all the animals of the woods, and this, with all their other senses always awake, renders it almost an impossibility to take one, save in the deep snows and crusts of winter. They are a wgndering animal, too, in the summer season,-having no peculiar abiding-place, and the one that made the track we saw, may have traversed hundreds of miles since he set his foot in that soft clay. They are as stupid in the presence of a blazing light, in the darkness, as the deer are, and like them, they may be easily approached with a boat in the night time.

It is some twenty-five miles from the entrance of Stony Brook into the Raquet, the point where we entered the river, to Tupper's Lake. We loitered along, enjoying the scenery, examining every pleasant nook, stopping to look at every curious thing that presented itself to our view, so that the night shadors gathered around us, before we had performed half the distance we had calculated upon in the morning. We landed for the night, and erected our shantee on the banks of the river, near one of the natural meadows I have spoken of, and before the sun was in the sky the next morning we were on our way again. Some three or four iniles below the shantee, a small but 
very cold stream enters the river. Just by the mouth of this, we lay to, to secure a breakfast of trout. We caught, as fast as we could throw, an abundant supply, and we stopped. Further down the river still, is what is known as the "flood-wood," a Red river raft in miniature. In a short bend in the stream, where the water is deep and sluggish, an immense quantity of trees and old logs, and all manner of driftwood, dams up the current, piled above the surface in all manner of shapes, and extending to unknown depths below, through which the river finds its way as through a great sieve. Over this "flood-wood," a distance of some forty or fifty rods, our canoe had to be drawn. It was six o'clock when we reached 'Tupper's Lake, of a calm, warm evening. . Our shantee was soon built, ant our smudge going, and before the twilight had fade? into the darkness of night, two weary men might have been seen out there, on the margin of Tupper's Lake, in a shantee built of brush, and a dense smudge near their feet, fast asleep on a bed of hemlock boughs, with a by no means handsome dog, as a faithful watcher over them. It is wonderful how sound and sweet a tired man will sleep on his bed of boughs, off there, in the clear pure air of the Shatageo 8* 
Woods. It is wonderful, too, how fresh he will feel in the morning, as his eyes open with the break of dawn. He feels that he has slept enough, and that his weariness is all gone. He feels no lassitude, no desire of the sluggard for "a little more sleep, a little more slumber." He starts from his green boughs, gapes, stretches himself, and is wide awake, and fresh as the balmy air of the morning. He plunges into the lake for a refreshing and cleansing bath, his muscles are strung for action, his nerves all quiet, and

"Richard is himself again."

We were startled, in the gray twilight of the morning, by a distant roaring; not like a waterfall, or faroff thunder, but partaking of both. We heard it several times, at short intervals, and were unable to account for the sound, until, as the light grew more distinct, we saw vast flocks of wild pigeons, winging their way in different directions across the lake, but all appearing to have a common starting-point in the forest, a mile or more down the lake.

"I understand it all now," said my guide; "there's a pigeon roost down there, and, Squire, if you've 
never seen one, let me tell you it's worth going miles and miles to see."

I had heard and read, of these brooding places of the wild pigeon, and was right glad to have an opportunity of judging of the truth of the statements in regard to them. We paddled down the lake, to a point opposite to where it seemed to be, and struck into the woods. We had no difficulty in finding it, for the thundering sound of those vast flocks, as they started from their perches, led us on. About half a mile from the lake we came to the outer edge of the roost. Hundreds of thousands of pigeons, had flown away that morning, and yet there were hundreds of thousands, and perhaps many millions, old and young, there yet. It covered acres and acres-I have no idea how many, for I did not go round it.

The trees were not of large growth, being mostly of spruce and stinted birch, hemlock, and elm, but every one was loaded with nests. In every crotoh, on every branch, that would support one, was a nestful of young of all sizes, from the little downy thing just escaped from the shell, to the full-grown one, just ready to fly away. The ground was covered with their offal, and the carcasses of the young in every 
stage of decay. The great limbs of the trees outside of the brooding place, were broken and hanging down, being unable to sustain the weight of the thousands that perched upon them. Evidently the wild animals had fattened upon the unfledged birds, that had fallen from the nests, for we saw hundreds of half-devoured carcasses laying around. The hawks and carrion birds congregated about. We herrd the cawing of the crows, and the hoarse croaking of the raven in every direction, and saw them at a distance, devouring the dead birds on the ground. We saw dozens of hawks, and owls, sitting upon the trees around, gorged with food, that flew lazily away as we approached. Every few minutes, would be heard the roar of a flock of the birds, as they started from among the trees.

After examining to our satisfaction, this wonderfu! exhibition of the habits, and instincts of this truly American bird, we took from among the largest of those in the nests, what would serve for our breakfast and dinner, and turned to the lake. As we passed back, we saw, just outside the roost, two gray foxes stealing away into the thickets. These, and such as them, were having a good time of it that season, among the countless hosts of young pigeuns. 
We struck across to an island, some half a mile from the shore, where we breakfasted upon young pigeons, broiled upon the coals. They were very fat and tender, and constituted a pleasant change from fish and venison, which, if the truth must be told, were becoming somewhat stale to us. This island contains from one to two hundred acres. We started Shack after a deer, which he coursed round the island, but, having seen that it was a doe, that might have had a fawn hid away among the bushes, we called off the dog. She had, however, a sharp heat, for Shack pushed her mighty hard from the word "go."

Tupper's Lake is the next largest one to the Upper Saranac, in this region of country. It may cover possibly as many acres, for it seems to be wider, but it is not so long, I should judge, by some three miles. It is impossible to describe to you this beautiful sheet of water. There are so many objects of interest, so much that is wild and romantic, so much that the eye loves to dwell upon, that it must be seen to be appre. ciated. As you enter the lake from the outlet, a precipice of solid rock rises on the right to the height of some fifty or seventy feet, the top of which is level and bare. Pleasant little bays steal around behind 
those massive walls, in the cool shadows of which, the trout congregate.

On the left, a beautiful prairie stretches away, skirted by tall trees, and as you look upon it, you can hardly believe that it is not a pleasant meadow, and you wonder where the farm-house, and all the cattle are. Directly before you, are several islands, all covered with evergreens, some high and rocky, others low and seemingly fertile, while here and there an im. mense brown boulder rises from the deep water, to the height of twenty or more feet, on which the eagle and the fish-hawk alight to devour their prey. There is no marsh, no tangled alders and willows, nu swamps around this lake. The shores are all high and bold, piled up with broken rocks, or with a white sandy beach between the water and the woods. When you enter the lake, no signs of human habitation, no evidence of civilization is to be seen, and in our voyage round it, we found not a single opening in the old primeval forests. Near the centre of the lake, is a most picturesque island, which is called The Devil's Pulpit, from the singular appearance which it presents, as seen while coming down the lake. This island con. tains some fifteen or twenty acres. Approached from 
the east, it rises gradually from the water, covered with a luxuriant growth of fir, hemlock, and birch. It increases in height as you advance, until, at the west end, it stands out a perpendicular wall of seventy feet. Not a ledge, arrayed in layers, but a square up and down solid wall, as if a gigantic boulder had been sawed asunder, and one-half of it removed. The top of this great rock is bare and smooth. You can approach and look over the precipice without danger, so level and flat is the surface. At the base the water is said to be some fifty or sixty feet, at least, in depth. I sounded thirty feet, and found no bottom. On the top of this rock, an Indian tradition says, the bad spirit preached to his followers congregated on the ice below, while a furious snow storm swept over the lake, and the winds roared and howled above the frozen waters, and went thundering and crashing through the old woods on the island, and along the shore. On the north side, and a short distance from the pulpit, are great steps, or successive breaks in the rock, up which he went to deliver his sermon, while on the other side, is a regular smooth descent, like the steep roof of a house, worn by the attrition of ages, down which, it is said, he slid when the service was over. 
Further towards the west, is a large islana con taining perhaps a hundred acres, and there are scme four or five others of equal size, as you approach the head of the lake. We gave Shack a turn on each of them with a deer, and he seemed to enjoy the sport quite as much as we did. He appeared to understand, from the time we landed on the first island in the Saranac, what was expected of him, for, though he never for a moment left us without orders, yet we would not be five minutes landed, before his uneasiness told us, as plainly as words could have done, that he was ready, and wanted to take a turn or two round the island with a deer. Some three miles from the head of the lake is one of the most beautiful bays of some fifty acres, that can be imagined. The entrance to it, is only a few rods in width, and you would sup. pose, viewing it at a short distance from the shore, that it was merely an indentation in the banks, so quietly does it steal around and behind the bluff point that stretches out into the lake. But on rounding this point, you find an exquisite little lake, walled in by low precipices, from which the spruce and birch trees shoot upwards towards the sky, and along the base of which, are piled fragments of rocks that have 
fallen from above. At the head of this little bay stands a tall old hemlock, "dead at the top," on which sat a great eagle, surveying calmly the "waste of waters," and which, when he saw us, leapt upwards from his perch, and circling round and round in his upward flight, then soared proudly away over the mountains. We paused a few minutes, by the mouth of a little stream, that had its origin in an exceeedingly cold spring a few rods from the shore, to throw for trout. We found them abundant, and very active in taking the fly. We threw only for experiment, and having become satisfied, we returned the half dozen that we caught to the water, and passed out into the lake. At the head of the lake, Bog river enters. It is a large stream, though a small river, and comes cascading down from a level plateau, some sixty. feet above the leviel of the lake. And herein is one of the singularities of the formation of this region of country. It seems to consist of a succession of planes or plateaux, rising one above the other', each having its series of lakes and ponds, the upper discharging their waters down steep declivities, or short rapids, to the level next below, and so on from plain to plain, until the drainage of all, flows off in a broad river towards 
the great lakes, the majestic St. Lawrence, and the sea.

Bog river has its origin in a series of ponds, laying away back towards the base of the Adirondack mountains, flowing for miles in a deep and siuggish current, then goes roaring down rocky declivities for, say fifty rods, then settles down to a still, deep stream, passing onward through other ponds and lakes, and finally ends its career in Tupper's Lake. For several miles back from the lake, it moves along with scarcely a perceptible eurrent, until it arrives at the brink of the plateau, or plain,-then it rushes down some twenty feet, not in a perpendicular fall, but over the sides of a range of solid rock, steep as the roof of our ancient Dutch houses, plunging in foam into a great stone basin of near half an acre, then it plunges down a declivity of like character, into a second basin, and then again over the steep but solid rock, and shoots in a boiling current far out into the lake. On the sides of the river, where it enters the lake, are broad flat rocks, shelving with a gentle descent to the water's edge. We landed on the left hand side of the river, and I prepared my fishing tackle, and threw across the cur. rent, where the river plunged into the lake. The fly 
had scarcely touched the water, when it was seized by a trout weighing over a pound. I had neither landingnet nor gaft. My rod was a long, elastic one, by no means calculated to lift a fish of that size from the water, and I had to play him till drowned or exhausted, so that I could draw him gently upon the shelving rock.

I took at this place a trout that I have no doubt would weigh two and a half-pounds, and singnlarly enough, I "hooked" him, not in the mouth, but through the back fin, close down to the back. Him I could not, of course, drown, and the fight we had was exciting enough. He bent my rod like a reed, in his mad efforts to escape. He went skimming away through the water, making my reel buzz again. Holding him always taught, he would for a moment seem to surrender, and then as I reeled him in, would go skiving away with renewed strength to the bottom, -now floundering on the surface,-now glancing away across the swift current, diving down towards the bottom, and again leaping above the water, darting here and there and everywhere, in his hard struggle for life. Strange as it may seem, the hook held in the strong cartilage of his back fin, until clean ex 
hausted. I drew him to my feet on the shelving rock, and secured him after an exciting contest of half an hour. I was loath enough to leave such rare sport, but I had already killed trout enough to make me feel somewhat conscience-stricken; for I had, to say the least of it, as many as we could possibly use, considering the hot and sultry weather.

We built our shantee for the night, on one of the islands near the head of the lake. 


\section{XIX.}

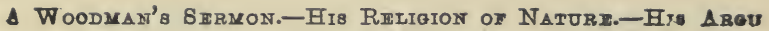
MHNT AGAINGT INFIDHitT.

THE next day was the Sabbath, and we made it a day of rest. Solitary as was the forest, and silent, so car as the church-bells were concerned, yet we felt that the commandment to respect the day was obligatory everywhere, in the midst of the wilderness. We remained by our shantee until near evening, when we floated out upon the silent waters of the lake, to enjoy the pleasant breeze that rippled its surface, and look upon the quiet scenery around it.

"Squire," said my guide, "the forest, in the sum. mer time, isn't the place to make a man forgetful of his Maker, and ain't calculated to strengthen the wicked feelin's of his nater. There's a great many things preachin' to him, as he wanders in the woods, among the wild and nateral things, and though may 
be he can't write out the sarmons, nor repeat the texts, yet he's all the time growin' stronger and stronger in his faith, and better in his heart. The tall forest tree preaches to him. It puts forth its little buds when the spring time comes, and spreads out its great leaves in the summer months, that make a cool shade in the heat of noon. When the frost comes, those great leaves wither and die, and the fall winds scatter them abroad, to malre focid for new things that grow up in the wild wocd. I'he great tre; itself, when decay seizes upon its trunk, and the earth-wo ims bur cough in its roots, drops its branches, and at 'ast falls to the ground. Well, those little buds, and them great leaves, and the frosts and fall winds that scatter them abroad, to become aliment for new vegetation, are the heads of the discourse; and the great tree itself, when it falls to the earth to decay and rot, is the admonition that closes it. It tells him the history of his own life, and talks to him about his own schemes, and hopes, and passions, anc his firal destiny at "ast. The little buds tell him of the time $r$ hen he was smart and young, with his thousaud childish schemes and boyish plans. The tree, in its maturity: reminds him of the vigor, and strength, and pride of manhood, and the 


\section{A WOODMAN'S SERMON.}

falling of the great leaves tell him how plan after plan and scheme after scheme passes away, and how one after another of worldly hopes and objects of affection will fall from around him, and how, when the winter of age comes, he must fall as the great tree falls.

"The brook that comes down from the hills, preaches to him. He looks upon its waters in their ceaseless flow, onward and onward forever. How it comes up from the secret spring in the mountain, and moves forever away to the large stream, and away still to the great river, and away again until it is lost in the vast ocean.

"The little fountain that sends forth the tiny - brook, tells him of his infancy. The stream that goes cascading and leaping down the steep places, laughin' and chatterin' in its haste, tells him of his boyhood. The river still pressin' onward, speaks about his strength and vigor in the strong time of his life, and the final ending in the great ocean, reminds him of the grave at last. The waters as they move onward tell him, that in his course of life there is no stoppingplace. That onward, and onward, is the word. Hours, days, months, and years, steal away; time 
flows, and flows on with him, like the runnin' waters, and like them he must be lost at last in the great ocean of eternity. The squirrel preaches to him; he sees the little animal gatherin' his store of nuts, workin' with cheerfulness in the summer, to provide against the barrenness of the winter months. That little senseless thing that follows only a blind instinct, tells him that there is a great winter in the far-off future, and the summer is the time to provide for its coming. That the idle shall starve in its dreariness, and the profligate perish under its pressure. The birds in their joyous songs among the branches of the tall trees, preach to him. They tell him to go cheerfully on his way of life, in thankfulness to Him, who scatters so many blessings on the trail that he follows. They say to him, that $\mathrm{He}$ is a kind and beneficent God, who made them so joyful and happy, and gave them food, and cool shades, and the branches, among which they could sport, and build their nests, and gave them glad voices to carol in praise of Him who provided them with all these. Even the tall mountain, rearing its bare head to the clouds, defyin' the storm and the tempest, has its sermon. It tells him of the might and majesty, and the fixedness of the 
purposes of the great God. It is a sign of his strength and power. Who would not stand in awe of Him, who piled up those massive ledges of impenetrable rocks, and bid them stand there immovable forever?

"I ain't a wise man, Squire, and may be not what the world would call orthodox in my faith; but if I'd never seen a church, nor a bible, nor a preacher, my belief in the existence of a great and a good God, would have been as fixed and fast as it now is that I exist. When I see the seed that is planted in the ground, bring forth grain,- - the nut that falls to the earth, sprout up into a tall tree,-when I see that the animals that live in the water, and on the dry land, and the birds that fly in the air, all are fitted for the elements in which they move,-when I see the tree blossom, and bring forth its fruit, - the sun, and the moon, movin' in their regular course in the heavens, and the stars shinin' like candles in the sky at night, I say to myself, all these things never happened by chance. There's a God that made them all. That He is wise I know, because there is no confusion, or jostlin' among the millions of created things, that he has peopled the world with. That he is benevolent I know, for he has made provision for the happiness, 
and enjoyment of every creature that came from his hand.

"That there's a life beyond this life I believe, because the Bible says so, and because, to my understandin', nater everywhere says so. I see the brook always runnin' on, yet never wasted. I see the seasons come and go, the trees blossomin' and renewin' their green coats every year, and know that they always have, from the beginnin' of time. Io see and know, that nothing in all the world perishes utterly. I see all this, and I say to myself, the spirit of a man never perishes-it must be indestructible as the things that go to make up his body. I see, too, man standin' at the head of all created things. The earth, the air, and the water, and the things that belong to them, all made subject to his will, and provided for his use. I look upon the sun, and the moon, and the stars, all ngntın' his path, and all the mighty universe spread out above and around him, and I say to myself, it can't be that all this was made, that man might just look upon and admire them-feel for a little time their benefits, and then lay down and perish utterly. It can't be so ; there must be something above and beyond this life, and the spirit of a man must survive for 
good or for evil, the body that goes back to the eas $h$. I don't care how larned a man may be; he may traik wisely, and knowingly, about the sciences, he may confound me by a thousand things I don't and can't understand, but when he denies the existence of a great Power that created the sun, moon and stars, the earth and the countless hosts of things that swarm upon its surface, and swim in its waters, who denies the existence of a soul, and of an hereafter, who says there is no Heaven, and that the grave is the final end, I set him down as one who has something wrong in his upper works. He ain't a wise man. He don't reason like a sensible man, and I'm agin him.

"I mind once, I was out for a good many days, in the woods, with such an infidel man from Boston. He had all the signs of a gentleman about him, and didn't seem to have any ill will agin any living thing, yet as sure as I'm in this boat, I was afraid of him. To hear him talk, made me kind 'er creep all over. He seemed to take pleasure in denyin', and laffin at the idea of there being any great Creator, or any soul, or and eternity. I felt scary in his company, and many's the time. I've got him, under one pretence or another, to go before me, for fear he'd take a notion to shoot 
me; anc the last three or four nights we stayed in the woods, I didn't close an eye till I saw he was fast asleep. He could out-talk me, and outreason me; but he didn't shake my faith. I mind one day he was sittin' on the bank of a little stream that came laffin along down from the hills, and he was tellin' how everything came by chance, and I asked him what made that little stream run down into the valley, and he said, it's gravity. Well, we passed along, and came to another small stream, and I put him the same question as to that, and he made the same answer. 'Well, Squire,' said I, 'ain't there some place in the world where the streams run up hill ?' 'No,' said he, 'it's a law of nater, all over the world, that water shall always run down hill.' We came, after a little, to a great oak tree; I looked around, and after a good while I found an acorn that had sprouted up in the spring, and had sent out a little tree twice as long as my finger. 'Now,' said I, 'Squire, did that great oak always stand there?' 'No,' said he, 'it grew up from an acorn.' 'What,' said I, 'was that oak ever a little thing, like this I hold in my hand ?' and I showed him the acorn, and the sprout I had found 'Exactly,' he replied. 'Well,' said I, 'do all great oaks spring 
from acorns? Don't they grow from beech nuts, or hickory nuts, and don't they start up sometimes tall trees, at once?' 'No,' said he, 'its a law of nater that every fruit can bring forth only the same kind of tree that bore it,' and 'he talked larnedly about the nater of trees, and their growth.

"As we passed along, I saw a bird fly out from a bush, and I saw she had built her nest there, and it had five little eggs in it. 'Look here,' said I, 'Squire, how came all these twigs and this moss, and thistledown, woven into this bowl-shaped moss, in the branches of this bush?' 'Why,' said he, 'you know well enough, that's a bird's nest, and that the bird brought them, and mixed them into that shape for its nest.' 'Well,' said I, 'them round things there,' pointing to the eggs, ' did they fall from the trees?' 'No,' said he, 'you know very well, they're the eggs, of the birds.' 'But,' said I again, 'if I plant 'em, will they grow up into bushes, with birds nests in their branches, with eggs in them?' 'Tucker,' said he, 'you're making game of me; you know as much about them things as I do, and may be more,' and he went on to tell how natur' had made a law of instinct, that taught birds how to build their nests, and hatcls 
their young. I couldn't understand all he said, though he didn't seem to want to confound me by his larnin'. When he'd got through I said to him, says I 'Squire, who made these laws of natur', as you call them, that make water, always, and all over the world, run down hill, and great oaks grow up from little acorns, and teach the birds to build their nests, and rear their young? Who made these laws, and how does it happen that when everything came by chance, as you say, everything seems to be governed by regular laws, that makes like causes produce like effects, all over the world. I won't undertake to argy the pint, but to my notion, what you call natur's laws is, after all, but carryin' out the plans of the great God of natur, and that these things can only be so, because he willed 'em to be so. Chance always makes confusion, mixes up things, and you don't find any confusion or mixen up in the laws of natur', or among the things that exist in natur'. They never rub agin each other, but always work safe and smooth.

"I mind he said to me one day, 'Tucker,' says he, 'if there be a Providence that made and rules all things, that is infinitely powerful, wise, and just, how is it that all the world ain't honest and happy, and why is it that 
he don't so order it, that all shall have an equal por. tion of enjoyment in this world? Now you know it ain't so. Some are sick, and in pain all their lives. Some are hungry and cold. Some go sorrowing all their days; all that they love are lost to them, and they stand all alone in their desolation, like some tall forest tree that has been riven by the lightning. Honest men have been convicted of crime, and buried in prison, or perished on the gallows.' In this way he argued with me, and troubled me; for, Squire, I kept. thinkin' and thinkin' on what he said, till, while I I didn't exactly doubt, yet my mind became uneasy. But at last it came to me, that man at best is but a weak and feeble creatur', and his ways ain't the ways of the great Creator. That the mystery of all this belongs to that portion of the great plan of the universe, which is not revealed to man, and I remembered the words of a preacher I heard once, who took the hand of a weeping mother from the cold forehead of a child she loved, and as he lifted it from the face of the little one that was dead, he pointed upwards, and said, ' $\mathrm{HE}$ ordereth all things well.' So I said to myself, when the arguments of that infidel man rose up to trouble $\mathrm{me}$, 'HE ordereth all things well ;' when I look upon 
the uneven things that happen in this world,--how hard the lot of one, and how happy that of another is, I say to myself, 'He ordereth all things well.' There's a great many things I can't understand, and some that the wisest men can't understand, and the dealin's of Providence with human fate, and human destiny, is - one of 'em. If he troubles the just man, it is for some wise and benevolent purpose, that will be made known in time or in eternity.

"I'm a poor man, Squire, and an ignorant one. I don't care about riches, but I should like to be wise ; but I would not barter my faith in the good providence of my Maker, for all the kingdoms of the world, and all the knowledge that human wisdom ever attained to. I don't belong to any church, for I don't clearly understand the difference in their doctrines. But I've a simple doctrine of my own that I hold to, and it's this: that the man who believes in God, and fears him, who does the thing that is right, may go on his journey of life rejoicing, like the running stream that travels quietly to the ocean, and lay down at last, in the hope of a place among the happy hereafter. Not that I believe in his being saved by the merit of his works, for man is a sinful and erring creature at 
best, but there is One who can wipe away the sin that is repented of, and lead him safely home at last. This is my faith, that I gather from nater and from the Bible and while I interfere with no man's opinions, I shall cling to mine till I die, and take the risk of their carrying me safely throus, h. But I never want to see the man again, who says there is no God."

"Well," said I, "Tucker, you'll see no such man in me, and you've preached a better sermon than some I've heard from Doctors of Divinity." 


\section{X}

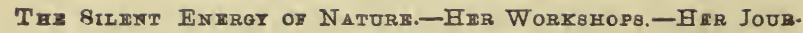
N IYMHN.

IT is a pleasant thing to rise with the early dawn, on the shores of one of these beautiful lakes, and watch the departure of the stars as they disappear, one after another, from the sky; to see the twilight fading as it were into day; to see the spectral and sombre shadows of the forest vanish away, the clustering trees, that stood like so many ghosts solemn and moveless in the darkness, assuming form and shape; to hear voice after voice, of the hundred that belong to the morning, waking from the stillness of nature's repose, and see the brightness of the perfect day, spreading its glories abroad over all the earth.

On this island, we noticed a variety of beautiful wild flowers. The rose, blossoming from its short bush, that sent its roots among the moss, and drew its 
sustenance from the crevices in the rocks. The wild violet, along the banks of the lake; the balm that grew in the moist places; and the lady-slipper, that sprung from the decayed leaves beside the fallen trunk of some great tree. All these, with many others, that as yet are nameless, while they could not rival the productions of modern gardens, yet possessed a modest and simple beauty, well worthy of a place in the arcana of the florist. We spent the day in paddling from island to island, and floating along under the shade of the tall trees that grew along by the water's edge. It has been said by somebody, I cannot now say who,-the sentiment, while I endorse it, is not my own,- - that there is a luxury in laziness, superior to almost every other luxury. To enjoy it, one must be away from the disturbing elements of civilization, beyond the sights and sounds, and the conventional proprieties of artificial life; where he can lounge in listless dreaminess, build his castles in the air, and not have them knocked to pieces by some stern reality, or toppled down by some practical thought, forced upon him through his eye or his ear. He must be haunted by no care, fretted by no business, disturbed by no necessity, nor hurried by the calls of duty. This lux:- 
ury we found that day, in all its beatitude, among the cool shades of those beautiful islands, beneath a balmy sky, fanned by a cooling breeze, breathing the odors of the wild flowers, and regaled by the songs of the birds.

"Did you ever think, Squire," said my guide, as he plucked a wild rose, that reared its modest head beside the boulder on which we were sitting, "how quietly nater goes about her work, and how silently she makes and finishes the beautiful things we see around us? It ain't so with man. He works with a great noise and bustle; when he builds his steamboat, or his house, or his great ship, he hammers away, and the clank of the machinery is always thunderin' upon the ear. The big sledge rings against the great anvil, and the hammer echoes as it drives home the nail or the spike. His saw grates and hisses, as it shapes the plank, and his axe speaks out as it hews the timber. His huge water-wheel goes grumblin' on its rounds, and his steam-engine puffs and blows, as if its lungs were troubled with the asthma. I was down to Plattsburgh one day, and went into a machine shop where there were a great many men.at work, ham. merin', and turnin', and shapin' iron into machinery: 
The Silent Energy of Nature. 205

and tho' everything went on regular, yet there was noise enough to make a man onused to it crazy. I saw them puttin' together a little steam-engine, and saw how smoothly it worked,-all its parts fitted like a shoe to its last, but I was thinkin' how many noises it created to build it. Now it ain't so with nater. You can't see her work, nor you can't hear her work. She moves on silent, but sure, and her work is all done without a sound to break the stillness. Look at this little flower. Yesterday, may be, it was a bud; to-day it is a rose, and, if a thousand men had been watchin' it, not one could have seen or told when it changed from the bud to the rose, and yet it did change. Look at that great tree, it is taller than the mast of a ship. See its great branches and its broad leaves. It was once but an acorn. It sprouted and grew to what you see, and if all the eyes in the world had watched it, not one could have seen it grow. Nater started it from the ground, and built it up as it stands there, and if all the world had been listenin', they couldn't have heard a sound as she put it together. Look away out over the woods, and see the broad forest wavin' there as far as your eye can reach. Think of that vast wilderness of trees, and all the 
smaller things growin' beneath them. What is the proudest work of man, to that great creation of nater that lies spread out before you? In the creation of it all, nater made no sound. She didn't wake a single echo. She moved on silently, steadily, and that great forest rose up, finished, and not a noise stirred the air in all that mighty work. You see a farmer sowin' his seed, and you know that a field of grain will follow. But you may watch, and all the world may watch and listen, and not one can see the blades come out of the ground, and yet they will come out of the ground; not one can see the grain grow, and yet-it will grow. Not one can see it ripen, and yet it will ripen. Nater will finish her work to the ripened crop, and the eye that watches ever so closely, or the ear that listens, can't see her work, nor hear-her work, and yet she works on, day and night, week-days and Sundays, till her task is done.

"Take the little child in its mother's arms, how weak and feeble it is. It don't know but little, and what knowledge it has, is only instinct that belongs to the young of all animals. But there may be in it, what will one day be great wisdom, and a strong tall man. Watch its growth. It passes from infancy 
from feebleness to a stout boy, and again, a little longer and it is a powerful man-with mind and body perfected. But you may watch it ever so closely, and and you can't see it change, though it does change, you can't tell when thought passed into its mind, nor when strength passed into its limbs. All you can say is, that it has changed, from the helplessness of infancy, into the stature and strength of manhood. While you was watchin' nater was workin' in her silent but sure way, perfectin' and perfectin' its job, and may be laffin at your trying to see her foot-prints, or hear the sound of her machinery.

"And just so it is with the countless labors she performs. You don't hear her water-wheels, nor her steam engines, you don't hear her saw or her hammer, she moves along in her great machine-shop, with a foot that leaves no track, a voice that utters no whisper, a hand that brings to the senses no sound. It's a wonderful energy Squire, that nater brings to the creation of her works, so silent, so mysterious, that shows us its countless productions, while it defies us to search out the way she placed them before us. I've often thought I'd like to look into nater's workshop and see how she makes the thousand things that 
come from her hand. To see the invisible agencies, the viewless mechanics at their labors-to see where they get the materials that they work up into the things that grow. To find out where they bring thought and wisdom from, that they put into the mind of a man, and the instincts that make up the knowledge of dumb animals. To know where the strength comes from, and the flesh and the bones, that change the little child into a great stout man. That would be a sight Squire, worth lookin' at. But we shan't see it, and no man will ever see it. It's among the hidden things that the eye of livin' man can't look upon, nor his cunning find out." 


\section{XXI.}

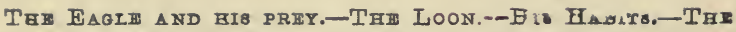

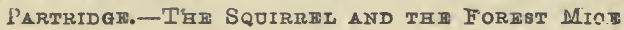

As we paddled down the lake we saw a brood of half-grown ducks, some twenty rads from the shore, swimming and gyrating round the old one, diving and flappiring their unfledged wings along on the water, seemingly in a.most playful humor. We paused close in by the shore, and were watching their sports, when we heard the alarm cry of the mother, and they instantly scattered-pulling with feet and wings for the shore, quaking and evincing in every way the wildest terror. Suddenly a bald eagle came like an arrow, from his perch among the trees on a high bluff beyond them, and seizing, as he glanced from the water, one of the brood in his great claws, bore it away round the point, whence he made his stoop. It was a beautiful exhibition of sikill, and though it made a 
vacancy in that brood of ducks, yet it was a sight I should have been loath to miss. It was all done in an instant. There was no pause in his flight; as the eagle seized his prey he glanced upwards and wheeled in the air with wings apparently unmoved, and then flew off to devour it.

"There, Squire, I have seen that thing done a hundred times," said Tucker. "That eagle has been watchin' that brood of ducks, may be an hour, and his mind was made up which one he'd take before he started from his perch. He don't shoot at random, anc don't often miss his mark. I've often thought it must take a great deal of trainin' to do it. But I suppose it's nater or instinct as you call it, and old Pete Meigs always said the eagle's first stoop is as sure as his bundredth or his thousandth."

We waited a long time for the frightened water-fowl to come from their hiding places. At length we saw the old one steal cautiously out from among the reeds, and turn up first one eye and then the other, as if to see that her enemy was gone. She seemed to become satisfied that the danger was over, and in answer to her low call her little ones, one after an. other, gathered around her. She went swimming and 
quaking around among them in a restless and uneasy way for a little time, as if counting them up. But she soon forgot the lost one, if she missed it, for in a few minutes she became quiet, raised herself partly out of the water, flapped her wings, and then fell to straightening out her feathers with her bill, as if nothing had happened.

"The eagle," said Tucker, "knows what waterfowl it's safe to make prey of. He never takes the loon. That bird, as you see, floats away out on the water, and don't seem to take any notice of the eagle. He's got a long, sharp bill, like a dirk, and he uses it like one, sometimes, too. I mind once, I was over on the Shazee with a man from down south, who had a large water-dog that he'd larnt to fetch and carry, and when he shot anything on the water, he'd send his dog, Nero, as he called him, in after it. Well, one morning a loon was plumin' himself near the shore, and the gentleman crept carefully down to the bank of the lake, and with his gun loaded with duck-shot, fired upon and wounded it, so that it couid not swim fast or fly away. He sent his dog to bring it to the shore. Nero plunged in, fierce enough, and swam boldly up to it. The wrunded bird lodged the grab 
the dog made at it, and struck its long sharp bill into his neck in a way that made him howl. 'Nero turned to put out for the shore, and the loon gave him another stab in the ham, that sent him ahead crying ki! hi! at every pull. The poor dog came out of the water with two great wounds, and bleeding like a stuck pig, very much to the amazement and wonder of his master. After that Nero took two looks at the birds his master sent him into the water after, before he ventured near them. Now, Shack there, would have declined that job. He knows what the long sharp bill of a loon means, though how he got his larnin' on that subject I can't tell. I know he never was wounded by one in his life. But it's of his knowin' ways, and may be, he has studied it out by seein' the loons I've shot afore now, and may be he's got hold of the truth by hearin' me tell about the trick that bird played on the gentleman's water-dog.

"The loon, Squire, is a curious bird. You hardly ever see two together sociable like, though there may be more than that number, in one of these little lakes at once. But they're always a great ways apart, and never seem to have anything in particular to say to one another. I never saw a young loon in my life. 
Where they breed, I don't know, but one thing I'm certain of, they don't breed in these waters. You may come out here, airly in the season, and you won't see a loon in all the lakes. When the weather gets warm, you'd be woke up in the morning by their clear, loud, ringing voice, and you'll see may be two or three, off in different directions on the water. You may stay all summer and you'll see them there, and always apart, and you won't see any others. Along in the fall you see them as usual on the lake before you go to your shanty at night, and when you get up in the mornin', they're all gone, and that's all you'll know about 'em, if you stay among these lakes studyin' their ways a dozen years. And when they go, you had better go too, or make up your mind to be out in the woods in an ugly storm, for in a day or two it'll surely come. This much I've learned, and when they start, I always start too.

"There's another queer water-fowl, that little dipper as we call him, sittin' out there like a cork on the water. He, too, is always alone, and don't build his nest in.these parts; as I could ever discover. We used to have a deal of fun with them chaps when we had flint locks, before the percussion caps (ame inta 
fashion. When I've been out to these lakes with people that thought themselves great shots, and could "to the thing handsome too, I'd point out to 'em one of them little dippers that would be eyeing us, may be ten or twelve rods off, as he sat lightly upon the water, and ask the marksman to shoot it with his rifle. Well, he'd draw up, thinkin' to fetch the bird sure, when at the flash, quick as lightning down would go the little fellow under the water. The ball would strike may be exactly where it sat, and the marksman would think he'd shot it into a hundred pieces, but in a moment the bird would pop up, and raising itself on end flap its wings, throwing the water from them, and would seem to say to his enemy 'do that again.' I've seen a man waste twenty charges, one after another, in tryin' to shoot one of them divers. Every time it would dodge at the flash, and be under water before the ball got to it. And it sometimes seemed to me as if the little fellow enjoyed the sport, as it never thought of getting beyond the range of the rifle. But I never tried the percussion caps on 'em, for I don't like to take the hazard of killin' one of the happy little things by way of tryin' the experiment."

Along in the afternoon we landed in a little cnve. 
I heard the drumming of a partridge, which is one of the queer sounds of the forest that one hears towards evening on a summer day. It commences slow at . first, like measured beating on a muffled drum. The blows increase in rapidity, until in a quarter of a minute they become so rapid that they are undia tinguishable to the ear, and for another quarter of a minute they roll like that same muffled drum beaten by a nimble-handed drummer. There is a singularity about the sound. You cannot tell whether it is near or far off. For aught you can say, it may be twenty rods or a quarter of a mile distant. And then, too, it is somewbat difficult to tell from what direction it comes. At first you think it is on this side of you and then on that, and you will hear it more than once or twice before you make up your mind positively as to the direction of the sound.

I listened until I was satisfied of the point from which, in this instance, the sound came, and crept carefully in that direction, intending to satisfy myself of the manner in which a partridge makes this drumming noise. After moving cautiously some thirty or forty rods, I saw my bird standing upon a $\log$, picking and straightening out the teathers on his tail, and along on 
his sides, as if dressing himself for a tea-party or a ball. Presently he straightened himself up, on tip. toes, beat his wings not against the log on which bo stood, but against his sides, slow at first, and then faster and faster until the "drumming" was for a few seconds a continuous sound. I saw him thus drum some eight or ten times during the half hour that I was watching him. He did not discover me and I did not disturb him. I was anxious to learn, if I could, his object in thus beating a tattoo on his own ribs, and thought I discovered it when I saw a hen partridge hop on the other end of the log, and walking leisurely up to the drummer, seat herself quietly by his side. They sat together a few minutes, and then left the log and sauntered away among the bushes.

While I sat watching them, I was greatly amused with the conduct of a squirrel in my neighborhood. I first saw him as he came down from the branches of a tree, a short distance from where I sat, and went hopping about, turning over the leaves, and, every now and then, cocking himself up on his haunches, to eat the beech-nut he had picked up. He jumped, after a little, upon the log where I sat perfectly still, and came within some ten feet of me, before he discovered 
- me at all. He made a few desperate leaps to the foot of a great birch tree, and running up the trunk some eight or ten feet, stopped and turned head downwards, and commenced chattering, as if inclined to hold a conversation with the strange animal he saw sitting there on the log. I did not move, and he seemed at last to entertain some doubt whether it was an animal after all that he had been so terribly frightened at He came slowly and cautiously down; stopped, as he reached the ground; sat himself up on end; and looked at me cunningly and suspiciously. He hopped a few paces nearer, and took another look, then leaped upon the log where I sat, within tẹn feet of me, looking intently and cautiously at me with his active, bright, little eyes,-turning first one side, then the other of his face towards me, and exhibiting almost a human curiosity to study out who or what I was. At length, as I was entirely moveless, he seemed to have made up his mind that I was nothing after all but a stump, or a thing that had grown there, and passed on in his hunt after beech-nuts, out of my sight.

I was amused, too, with the little forest mice, not much larger than the end of my thumb, that seemed to live in and under the $\log$ on which I sat. They 
would come out, and dodge about among and under the leaves, and over my feet; and one little fellow commenced gnawing with his sharp little teeth, at my greasy boots, while another seemed inclined to travel up the inside of the leg of my pantaloons. This was carrying the joke a little too far, and as I stirred. to prevent it, they vanished in an instant to their hiding-place under the log. 


\section{XXII}

'The Grat OwL.-Thir Wild Birds.--: ar Domb animal wiser in BIS IN8TINCTS, THAN MAN IN HI8 REASON. -THE FOLIY OF CRIME.

TowarDs sundown, as we were floating along the bluff bank of a cove, or little bay indented in the rocky shore of the upper island, I saw sitting among the clustering branches of a scrubby oak, that grew from the crevices in the rocks, a great gray owl, staring with his huge round eyes, with an aspect of profound wisdom at us. The feathers upon each side of his tiger-shaped head, stood up like cat's ears, and his legs were covered with pantalets of down, to the claws. A strangely solemn look, a deeply meditative gravity has the owl, as he stares out from his bush, and one not used to him, would mistake him for the great philosopher of the feathered tribe. That would indeed be a great mistake. He is a sluggish, stupid animal, a living illustration of the adage, that appear- 
ances are sometimes deceitful. He is not, however, without his parallels in the human species. There are owl men, as well as owl birds. With great developments, and small wit, profound gravity with little sense, solemn visages, and empty heads,-and who, though full of pretension, when sounded have no ring of the true metal, but dull and heavy like braśs. There was no object in making spoil of him, and we passed on, leaving him to his stupid meditations among the branches of his bush. We heard him, as we rounded the point, sending forth his hoarse, solemn, "To whit, to whoo, whoo" after us. The owl has but two changes to his voice,- - the one low, solemn, and hoarse, and yet heard at a long distance,the other a piercing, shrill, and intense scream, like the cry of the panther. The latter seems to be an alarm cry. It will break suddenly from the branches above you, sending the olood to your fingers ends, and startling you like a galvanic shock. Your hair starts up like "quills upon the fretful porcupine," and when your nerves subside, while you laugh at the absurdity of your alarm, you are nevertheless thank. ful that it was occasioned only by an owl.

The most common birds found on these islands, 
were the blue jay, the chewink, that takes its name from the resemblance its oft-repeated note bears to the word, the brown thrush, the cat-bird, and a bird of whitish color, like those which used, when I was a boy, to be called the snow-bird. There is also a variety of the wood-pecker tribe, from the large black, red-headed cock of the woods, that goes rising and falling in his flight, with a loud, clear, clanking voice, to the little chickadee that dances around the trúnk of the fir tree, looking for his insect or his worm; holding on with his tiny claws, now with his head, and now with his tail uppermost, crossways, and every way,-up, down, and around the tree in ceaseless activity. We saw a number of black and red squirrels, clambering among the limbs of the trees, or running about on the ground, in pursuit of the nuts that had fallen the previous season. There was no lack of life off here in the woods and on these beautiful islands, and all seemed to be busy and happy. We landed on the south point of the island for the night. The side of a large boulder offered a convenient location for a temporary shantee, which we soon built, and gathered spruce branches for a bed, and wood for our smudge

"I've often thought," said my guide, as we lighted 
our pipes after supper, "that the dumb animal is wiser in his instincts, than man is, in his reason and knowledge. Did you ever notice how happy every wild thing seems to be, and how all livin' things, but man alone, seem to enjoy themselves after the fashion of their naters? The bird hops, and flies about, and sings in his great glee, full of happiness, even while he is seeking the food that is to keep him from starvation. The squirrels go chatterin' and friskin' about, chasin' each other up and down the trees, leapin' from branch to branch, or skippin' playfully along the ground. The wood-rabbit leaps awkwardly about, cockin' his long ears at every sound, and nibblin' at the forest grass and tender leaves as he passes along. What of all the wild things that we see around us, seem to have a care or a sorrow? They don't distress themselves about to-morrow, for they know that it'll take care of itself. They ain't studyin' and contrivin' about the future, nor distressin' themselves about the past. They go straight along, enjoyin' the good the day or the season brings, contented whether it be more or less. A dumb animal never does violence to his nater. He don't eat anything that he don't like, and his instinct makes him avoid what ain't for his good. 
He don't go where he won't be comfortable, if he can help it, and he's always to be found in the place he's fitted by nater for.

"Now, Squire, it ain't so with man. He's an oneasy, discontented, restless creater, always pushin' ahead, reachin' after something beyond him. If he's got one loaf, he wants two, even though the first can't be but half eaten, and the second gets mouldy while he's bakin the third. If he's got one farm, he's strugglin' to get another, while the fruits of the first is being eaten up by the rats in his granary. The richer he gets, the richer he wants to be; and he goes on hoardin' and workin', till he wears himself out in gatherin wealth, that won't take one ache from his bones, nor stop the coming of old age, nor keep him an hour from the grave. He can't eat it, nor wear it, nor take it with him when he dies. I'm a poor man, Squire, but when I start on the trail that begins on the other side of the grave, I shall take as much of the treasures that people toil so hard for with me, as the richest man in the world. One man is always tryin' to search out wisdom, and to get a greater amount of larnin' than all the world besides. This, may be, ain't so foolish, if he don't neglect his body, or by over 
workin' his mind, bring pain, and disease, and weak. ness upon himself, and make himself old before his time. What if he gathers all the wisdom of the world, all the knowledge that human nater can attain to? It ain't much, at best, and the mountain he's tryin' to climb grows steeper and higher, as he goes up. He may climb and climb, till his eyes grow dim, and his head gets dizzy, but the top is further off than it was when he started. He may look back on the path by which he has ascended, and there's a thousand things to be studied out, that he overlooked as he came along. He goes deeper and deeper into the mist, and he learns at last, that the eye of man can't look into the thick darkness that nater has rapt round her. $\mathrm{He}$ finds out, in the end, that man's wisdom is at best foolishness, and what he thinks he has studied out, he ain't always sure that he knows. And then, Squire, what good does it do him, as a general thing, to roll up such a great heap of knowledge? It don't make him any more contented or happy. I am talkin' now about the man that sits up nights, studyin' and cypherin' out things, and wearin' out his body in tryin' to look into and understand all the hidden things of nater. He don't eat weil, nor he don't relish 


\section{THE FoLLy OF CRIME.}

his sleep. He wastes away, and may be dies, while the thing he's lookin' after, is yet a great ways be yond him.

"But it ain't the man that searches after knowl edge, that quarrels most with nater, and sets her up against him. I've seen young men, drinkin' and carousin', playin' cards, and swearin' and helping each other along in the ways of wickedness, in their young days, and I always said to myself, that if they'd just use the reason that God had given them, and look along down the trail of life, they'd see the great harvest of sorrow, that would surely spring up fi $>\mathrm{m}$ the seed they were sowin', in the spring-time of their lives. Such courses lead to great sins, and are pretty sure to end in an old age of repentance. When stiffness comes to the joints, and gray hairs gather upon the head, like the snows of winter on the mountains, it will be a sad thing to look back, and see only desolation behind them, while around them there is no comfort, and before them no hope. I've seen a great many men destroyin' themselves with strong drink, killin' their bodies, and their minds, and destroyin' all their human feelins', by indulgin' in the use of drinks that are onnateral, that take a great deal of work to $10 *$ 
make 'em taste pleasant. It's a strange thing, Squire, to see a man, that may be, has a wife and little chil. dren that he loves, that cling around him in their young affections, like the wild vine that creeps up, and hugs the trunk of the strong old oak. To see sich a man givin' way to destroyin' drinks, pluckin' up from his heart the love of the husband and the father, and castin' from him the fond arms of his little ones, and goin' straight along down to a drunkard's grave, in spite of his wife's anguish, and his children's tears. It's a sad sight Squire, but you and I have seen it more than once. It's a thing I can't understand-a foolishness that no dumb animals was ever guilty of.

"And then to see people breakin' the laws, plunderin' their neighbors, and may ke takin' away, by violence, human life. Crime, Squire, is a wonderful folly, outside of the moral wrong, and the sin against God. I was once down to Plattsburgh, when a court was sittin' there, and I went into the court-house, where they were tryin' a man for robbing a store in the night time. The jury were listenin' to what the witnesses were telling against him. It was all clear and straight, that he was the man who did the rob- 
bery, and the jury without going out, said he was guilty. I saw his wife, sittin' beside him, with a little child in her arms, and I heard her sob and cry, as she covered her face with her shawl, when she saw there was no hope. By and bv, the judge told him to stand up, and gave him the sentence that sent him to State's Prison for years. I never shall forget the sorrowful voice, nor the great tears that rolled down the cheeks of his wife, as she parted in her desolation from him. Then I thought to myself, Squire, what a wonderful foolishness is crime. Here was a man, and there are and always have been hundreds and thousands like him, who broke the heart of his wife, and destroyed the promise of his little one, brought shame upon his - kindred, and a great blight upon his own name, besides being shut up in a prison, and havin' long years carved out of a life, short at best, for a chance of gettin' by crime what he would have squandered in a month, and what he might have earned by honest labor in a year. No dumb animal, would have been guilty of such folly.

"Reason, Squire, is a great thing, but it don't save human nater from great and wonderful foolishness" 


\section{XXIII.}

\footnotetext{
Thx distit's Journat.-Wird BuIts and COWs, with antims

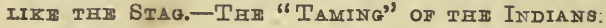

THE wind died away as the sun went down, to a perfect calm. The lake lay there in perfect stillness, its surface unruffled by a wave. It is impossible to describe the beauty of a calm, clear evening, on one of these lakes. The shadows of the mountains, and of the tall forest trees, reach out farther, and are reflected with a deeper and deeper shade, as the night approaches, from the depths of the quiet waters. The little bays, and wooded indentations along the shore, grow darker, and more solemn, while the mountain peaks stand out with a bolder, and sharper outline, against the sky. Each forest sound becomes more and more distinct, as the general hum of life sinks away into silence. Star after star steals out in its brightness, until all the "candles of the sky" are lighted, 
and in their proper places. I noticed this evening, that the trout of the lake, seemed to be holding a jubilee; from the time the sun hid himself behind the mountains, they commenced their sports. In every direction they were in playful activity. Here, one would be seen skimming along the top of the water, leaving a long, wake to mark the course he followed. There, another would come to the surface, and thrusting his nose upward, would pitch suddenly down, giving his tail a flourish in the air, as he disappeared again towards the bottom. Then another huge fellow would leap clear of the water, in his great glee, shake himself in the air, and then tumble back awkwardly into the lake. We took a turn at trolling among them, but they were too happy to bite, and we left them to the enjoyment of their sports.

"Squire," said 'Tucker,' as we were paddling leisurely along towards the outlet of the lake, "I've read in one of the books' printed by the State, that tells about the airly settlements of this country, that a great many years ago, when all the State of New York, and every foot of land south of the great lakes, and west of the settlements just along the sea coasts, clear to the Mississippi, and beyond that, too, to the 
ocean, was one great wilderness, a Jesuit missionary, thinkin' to convert the wild Ingens, and make Christians of 'em, passed up the St. Lawrence in a' canoe, and so on up old Ontario, and away to Lake Erie. It seems he wrote down the curious things he saw, and sent that writin' home to France, where it lay until a few years ago, when it was discovered, and put in print. I've been told that he was the first white man that ever passed_up the St. Lawrence, or coasted the Ontario-that he alone, of all the civilized world, had heard the roar of Niagara, or looked upon the falls of the Genesee. That was a great thing, Squire; but for all his writin' the world ain't much the wiser. He was a simple-minded man, who had no eye for nater, and took no notice of the wild things of the woods. In all the country he travelled over, he saw only heathens to be converted, and sinners to be saved. In all his wanderings he carried only a Bible, and talked with the savage Ingens only about their souls. It's a great pity, Squire, you and I hadn't been along that trip; the world would be wiser about the country as it then was, about the wild beasts, and birds, and game, than it now is."

"A man down to Plattsburgh, that I'd been out 
to the Shazee, and the Shatagee lakes with, showed me in a book the old Missionary's Journal, and I shall never forget the only things written in it about the game. I read it carefully, and know it all by heart.

"'Travelling through great prairies,' he writes, 'we saw in divers quarters immense herds of wild bulls and cows; and their horns resembled, in some respects, the antlers of the stag.'

"In another place he says, "Droves of twenty cows plunge into the waters to meet us-some are killed by way of amusement with an axe.* As near as I can calculate, this was on the St. Lawrence, down below the Thousand Islands, in the region of the outlet of the Champlain.

"Now, these wild bulls and cows couldn't have been moose, unless the nater of the beast has changed; for in all the woods there's not an animal so shy and and wild, and that shuns a man with such care. He's a cunning animal, and has ways that are not such as the missionary describes. He's a solitary animal, and lives away off in the deepest recesses of the woods, and don't congregate in droves. It don't seem to me that the buffalo ever left the rich pastures of the West,

* Documentary History of New York, vol. i. 
to wander away off north to the St. Lawrence, to starve in the woods in the winter, ana be eat up by the black fly in the summer, wher they'd fare so much better at home. It's agin nater that they should do so. It's true I've hearn tell of their paths over the Alleghany Mountains, and that in airly times they were found in Ohio, and may be in western New York; but I never believed myself they came so far east and north as this State; and there's no tradition of their havin' done so among the Ingens. Besides, their horns don't resemble the horns of the stag at all. Them wild cows and bulls, Squire, warn't buffalo, and accordin' to my notion, they couldn't have been moose, either. What they were is more than I know; I've studied. and thought about it a great deal, but it don't do no good.

"It must be true, for the missionary writes like an honest man, who fearen God, and wouldn't lie about what he saw. Besides, he don't tell any long yarn about it, nor any cock-and-bull story, but simply states the fact, and leaves it. It's a-wonderful pity he warn't thinkin' less of the sinners, and more of the things he saw on that first journey, among the wilds of the New World, for it might well be called new 
then. He didn't make Christian men and women of the Ingens, nor win them from their wild and savage way either. To them, he didn't d $\rho$ much good, and the world knew all it wanted to know about 'em. They were a cussed, scalpin', murderin', savage set, and warn't worth savin' any how. If that missionary had just told us all about the woods, and the game, the beasts, and the birds, and the appearance and nater of things, and especially all about them wild cows and bulls with horns like the stag, he'd a done something to be remembered by, and the world would have thanked him for it. But he told just enough to make the world want to know more, and to cuss and swear at him for not tellin' more, instead of goin' cruisin' after them blasted red skins. It's provokin', Squire, for men like you and me, to have such a little corner of the cover lifted up, that conceals so much knowledge, and lettin' us see that there's a great many things beneath it that we'd like wonderfully to know about, and then shutting it against us forever, especially when thinkin' and studyin' won't help us to find it out. I'm blamed if I havn't been mad with that missionary, ever since I read his journal. It's a thousand pities he didn't take an observin' hunter with him, who'd a set 
down on paper all about the wild beasts, and birds, and such things, while the missionary was writin' about the heathenish and savage Ingens. I'd give half a dozen bearskins for such a book, afore I'd give one for all the red cusses between the St. Lawrence and the Rocky Mountains."

"The ruling passion, Tucker," said I.

"I don't know precisely what you mean by the rulin' passion, Squire," he replied, "but at this day, when the world knows the nater of an Ingen, and just what they're worth, it's no great things to read about 'em, as they were two hundred years ago. But to my notion, as the country grows old, it's an interestin' study to look into things as they were so long back, and see what wild animals, birds, fishes, and such things, then existed; to know what of them have been pushed entirely out of the world, and what of 'em have been left, and to understand what changes white men, and tame life all around 'em, have worked on 'em. Now these things is a sealed book to us, jist because people that travelled in them days, didn't think what wonderful changes would be made in this great country, or were contrivin' how to make Christians and civilized people of the Ingens. It's always been my opinion; 
that the vateral place for an Ingen, is in the woods, like the moose, painters, deer, and bear; and that it's their fate to pass away with the forests, as them wild beasts do. I have hearn tell of some who have changed their ways, and become like white folks; but it's my notion they're like some tame buffaloes I saw in a farmer's lot once, down on the Connecticut. They made blamed mean-lookin' cattle, and stayed there only because there was high fences around 'em, and no prairies or wood to fly to. The stock wasn't thought much on. It cost more to improve 'ens than they're worth, and they'll die out, or be run out, 'jy crossin' the breed at last. 


\section{XIV.}

$\Delta$ Wild Cat.-Long Nhak.-Round Lakm.-Thi Lowrr Saratao -A Fight betwhen a Panther and a Bhar

WE returned to the foot of the lake, and towards evening we barke adieu with regret to this most beautiful of all the sheets of water in this broad wilderness. We left it as we found it, sleeping alone in the old primeval forests, full of 'the belief that it would one day be the resort of the thousand tourists or pleasureseekers, that fly from the hot atmosphere of the cities, to find quiet and repose in the country. We entered the Racket again, and rowed quietly down some five miles to Long Neak, a quiet little lake, beautiful but differing entirely in its characteristics from 'Tupper's Lake. Some half a mile below Tupper's Lake, the river runs square against a solid wall of rocks, some seventy feet in height, and extending near a quarter 
of a mile laterally, from which the current glauces away at a right angle, and flows for a mile or more through a natural meadow, which stretches away from either shore, to the width of fifty or more rods, to the woods that bound it.

Long Neak is some four or five miles in length, by one mile in width. At the upper end of the lake, where the river enters, the land is high and bluff, while in looking down towards the outlet, the eye falls upon a wide, green, natural meadow, upon which stand thick foliaged trees, and as you look upon it, you cannot persuade yourself that you do not see a broad and beautiful farm, with an extensive orchard and brave old elms, left standing as shade trees, when the woods were cleared away. But it is all wilderness, just as it has. been for thousands of years. We spent the day on this lake, and encamped on its bank at night.

Just before daylight in the morning, Shack started up suddenly from his bed at our feet, and dashed furiously into the woods; we heard him for a few rods, in hot pursuit of something, and then a clambering, like some sharp-clawed animal, and we knew whatever he had dashed out after, har taken to a tree. We heard a low, intense growling up among the 
branches, and my guide, as he sprung to his feet, exclaimed, "It's a wild-cat."

This animal is not uncommon in these woods, though we had not as yet happened to see one. We cheered Shack on, and he sat barking at his game till the morning broke, when we saw at some thirty feet from the ground, stretched out along a great branch of an elm, a catamount,- - his great, round, gray eyes watching, with intense malignity, his enemy below His head lay over on one side of the branch, and he kept up a continued low growl. He would have been more than a match for the dog, with his great claws and sharp teeth, but he lacked courage to come down, and have a fair fight on the ground. When it was light enough to make a sure thing of it, I drew up by the side of a sapling, and aiming carefully at his skull, fired; he drew his head back, with a convulsive jerk, between his fore feet, seemed to grasp, for a moment, more closely the limb on which he was perched, and then, as muscle after muscle relaxed, he rolled off, and dropped heavily to the ground. As he struck the earth, Shack was upon him; but that was needless,- he was dead. He was a small animal of his kind,five or six times larger than a house-cat, of gray, or 
rather a brindle color, with a head large in proportion to his body, and a tail some eight or nine inches long.

It was our intention originally to have traversed the whole line of wilderness, laying between Clinton, and the north of Herkimer counties, but we had dallied long by the way, and concluded to turn back to the foot of the Upper Saranac, and so out by the course of the Saranac river. We returned, therefore, to the foot of Tupper's Lake, and re-embarked. We visited the pigeon roost again on our way, and the evening of the next day found us at the cabin of the half-breed, on the bank of the little lake I have before spoken of. He proffered me the use of his bed again; but I had had enough of that bed, and preferred one of boughs, in a hastily-constructed shantee, on the lake shore.

The next morning we passed on to the foot of the Upper Saranac, and re-embarking, paddled up some two or three miles to the outlet; this we followed, and carrying our canoe a short distance round, or rather down the rapids, entered Round Lake. This beautiful sheet of water, laying between the Upper and Lower Saranac, is properly named, being nearly, round. and some ten or twelve miles in circumference.

Towarils the north-east shore, and half a mile from 
the main land, is an island of one or two hundred acres. Here we landed, and gave Shack a chase after a noble buck, that seemed to have appropriated the island to himself. The third heat round the island, he took to the water, and, by our permission, escaped to the main land. He had a mighty sharp run of about twenty minutes, and he won't forget, in a hurry, his adventures of that day. We dined here on broiled partridge, having for our desert wild strawberries that grew on the island around us. After our siesta, we started for the Lower Saranac, intending to pass the night on an island, a mile or two from the upper end of it.

"I mind a story old Pete Meigs told me," said Tucker, as we floated down the lake, "of a thing he saw once, over by the St. Regis Lake, a great many years ago, when he was out here alone in the woods. I've told you before, he was an old man, almost, when I was a boy, and he used to be away for weeks, and may be for months, alone among the woods, and lakes, and mountains of this wild region. He was a strange, solitary man, and a gloomy one sometimes. There was that in his history, that might well make him so, as I'll tell you afore we get home. He had no wife, 
nor children, nor any near kindred, and I believe he loved me mor'n he did all the rest of human kind. He didn't hate, or dislike anybody but an Ingen, and him he hated like pison, and well he might. If the dark deep woods could speak, they'd tell, may be, strange stories, of Ingens that crossed old Pete's trail in the forest, and never got back to their wigwams. But that was long, long. ago, while the grass was growin' on the graves of his father, and mother, and sisters, and brother, massacred by the murderin' cusses, and the thirst for vengeance was rank in his heart. But what I was goin' to tell you, is this :

"One day, he was passin' from St. Regis to Big Clear Pond, and in goin' over a ridge had sat down, on the trunk of a fallen tree to rest. As he sat there, he heard a crashin' through the brush, as of some animal, that seemed to be in a monstrous hurry to get away from somethin' that he seemed to think, warn't a great ways behind him. Presently a bear rushed by him, over the ridge, gruntin' and talkin' to himself, as is the way of the animal sometimes. He seemed to be orfully afraid of something, but had no idea that old Pete, and his rifle was around. Them things warn't very healthy for bears, and if that one had knowed 
where they were, I've a notion twouldn't have quieted his feelin's much. In less than a minute, the old man heard the long bounds of another animal, comin' like death on the trail of the bear, and a great painter, with every hair towards his head, rushed like fury by him, over the ridge in pursuit. Old Pete didn't feel sorry just then, that the animal hadn't seen him, but that didn't prevent his runnin' to the other side of the ridge, to see the fight, that from the nater of things, seemed sure to take place. Well, sure enough, about forty or fifty rods down the side of the valley, where the brush warn't thick enough to hide 'em, he saw 'em come together. The bear, the old man said, saw twasn't any use to run any further, and as the painter came on, he sot himself upon his rump, and faced him, and such a set of ivory as he showed, was a sight to see. But twarn't no use; the painter's back was up, and without stoppin' to ask any questions, he pitched in, and over, and over they went, down the hill, the bear hollerin' and bitin', and the painter screamin' and bitin' back, and tearin' with his long claws. The fight didn't last a great while. The teeth and claws of the painter, was altogether too much for the bear, and twarn't many minutes till 'twas all over, 
an. (he bear was dead enough. After the fight, the painour seemed satisfied. He warn't much hurt, and fell to mllin' himself over and over, among the leaves, and slidin' himself along on his sides, as you've seen a dog do, to wipe the blood off his hide, and then fell to licken' his legs and sides, and whatever other parts of his body he could get at, to make himself look decent and proper again. Old Pete thought 'twas time for him to take part in the fray; so creepin' to within shootin' distance, he sighted the painter with his long rifle, and fulled. The animal sprung into the air, and after tearin' the earth, and strugglin' and kickin', lay still, and the old man took his hide, as well as that of the bear, and went ahead. What the cause of the quarrel between them two animals was, old Pete couldn't find out, but it was pretty clear the bear had been meddlin' with something that didn't concern him, and got himself into a scrape that cost him his life.

"A painter, Squire, is an animal that has an on. pleasant way with him, whe his back's up, and it's well enough for everybody, and every animal, too, in these wood, to keep out of his way, and give him all the trail at such times. I never happened to see but 
one, under such circumstances, and he was so disabled he couldn't get at me. Both his hind legs was broke, by a shot I gave him, but he told me plain enough, that if he'd been well, 'twould have been an onpleasant neighborhood for me. I've hearn tell of the lightnin' in the eyes of a furious animal, and I reckon I saw it in his, and glad enough I was, to stand back, out of his reach. I settled him with a bullet through the head. Unless provoked or starved, he won't meddle with a man. Let him alone, and he'll let you alone. Like all other animals of his kind, he's got more strength than courage, and unless cornered, don't like to fight. I never feel afraid of painters. I've shot a good many, first and last, but as a general thing I shouldn't meddle with 'em unless I could have a dead shot. Woundin' a painter, or a bear, is a bad. business, as I've heard, and I've let 'em escape afore now, when I wasn't sure of killin' 'em at the first shot. They're most all gone now, and it's only once in a great while, that we hear of one. Five and twenty years agc it warn't much of a thing to brag on, to bring in the skin of a painter, or a bear. But they're passin' away, and it won't be long till we'll have to look into history for an account of 'em, as well as of the 
moose, and catamounts of the Shatagee country. The Ingens are all gone, and the other wild things will follow, and such men as old Pete Meigs and I, will be gone too. People won't want a guide, for there won't be forest enough to get lost in. It won't be any great loss to the world, may be, we ain't of much practical use; and when our vocation's gone, we von't be wanted any longer." 


\section{$\mathrm{XXV}$.}

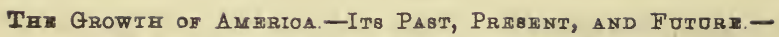
A. WOODMAN's IDHA OF EXPANBION

WE rested for an hour, within the shadow of the mountain, near the south-western margin of the Lower Saranac. Though the day had been exceedingly hot and sultry, it was delightfully cool and pleasant here. The leaves stood still on the trees, and no wave ruffled the bosom of the lake. The shore was piled up with boulders, and the bottom, destitute of grass and weeds, and covered with clean smooth stones, shelved away into the deep waters, wherein we could see, as we looked over the side of the canoe, abundance of trout glancing and sporting beneath us. We did not trouble them. We were too indolent, and happy for that. I can conceive of no paradise, to one who is pressed by no care, who loves quiet, who has a taste for wild, natural scenery, like that of float- 
The Past History of America. 247

ing of an afternoon, along the shores of one of these beautiful lakes, in the deep shadows which the hills throw out upon the water, listening to the forest sounds, breathing the pure air of the mountains, and looking upon the green woods that stretch away, and in receding upward seem to pierce the sky in the distance.

"Squire," said my guide, "I've often thought that this country was intended, one day, to make a great noise among the nations of the airth. It has gone ahead with such wonderful long strides, since it got free from the hold that England had upon its neck, and is pushin' forward so fast, that no man can calculate when, or where it'll stop. I've read in books, and hearn it told, by men who had studied into the matter, that when Gineral Washington had got through with his fightin', and sent his army home from the wars, there wasn't more'n three millions of people in all the United States, and that they were about as poor as seven, or eight years of fightin', and other troubles could make 'em. That there warn't any factories or machine-shops to speak of, in all the country. That the States hadn't any ships on the ocean, and not a water-craft on the great lakes. 'That there wasn't 
a canal in the whole country, and that the government owed hundreds of millions of dollars, and hadn't the first red cent to pay with.

That was a bad fix for a country to be in, Squire, and he would have been a pretty bold man, who would have ventured in them days, to foretell what a wonderful change sixty-five years would bring about Call back, if such a thing could be, the spirit of one of the men of the revolutionary times, and show him what this country has become, and may be, he wouldn't open his eyes some. Take him around the country, and show him the swarmin' hosts of twentyfive millions of people, in place of the three millions he left, when he laid down in the grave. Take him out on the sea, and show him the great ships of this 'country, sailin' to every part of the world, loaded with the goods of her merchants, and her tall war-vessels, lookin' into every harbor of the ocean. Point out to him her mills and her factories, standin' wherever a stream comes, down from the mountains, or a river leaps over a precipice, the clank of their machinery, minglin' with the roar of the waters. Tell him to look upon the canals, broad as rivers, extendin' through the great State of New York, from the tide waters, 
away to Lake Erie, and Lake Ontario, and old Cham. plain, and show him the four or five thousand boats, constantly movin' upon their waters. Point sut to him the tracks of the railroads, crossin' each other all over the face of the country, like lines upon a checkerboard, and show him the iron horse dashin' away with his long train of cars, thirty and may be forty miles an hour, and let him hear his mighty scream. Tell him to look upon the great rivers, and see the gigantic steamboats movin' away, like a whole street of a city, fifteen or twenty miles an hour, agin' wind and tide. Tell him that every dollar of them hundreds of millions, has been paid, and that mor'n forty mill. ions have been divided among the States. Tell him that the thirteen States, that he left behind him, have come to be thirty-one. That some of them are away down on the Gulf of Mexico, and one of 'em on the other side of the Rocky Mountains. I reckon, when he comes to understand all this, he'd be considerably astonished, and would wonder how it could all have happened.

It's a curious thing, Squire, to look back and see how amazingly this country has gone ahead, and to fo'low its trail, as it moved, like a giant, onward 
Some fifty years ago, she opened the line fence that was on the outside of her, and when it was built up again, Florida and Louisiana, with their millions upon millions of acres, land enough for half a dozen kingdoms, was on the inside of it. Another gap was opened, four or five years ago, and the State of Texas was fenced inte the enclosure. Later still, the old line fence was pulled away, and when it was built up again, it had nearly as much again of territory inside of it, as it had before, and all the wonderful gold mines of Californy, in the bargain; and now while she holds fast to all this, she's talkin' about fencin' in Cuba and the whole of Mexico, and lookin' on the other side, even of them, to see what lays over there, to be speculated on, when she's secured them.

"This country, Squire, ain't like any other country in the world. Its airly history ain't like the history of any other. Its first settlers warn't like the settlers of any other, and its people ain't like any other people. This warn't a country, when it was wild and nateral like, that folks could come to, and live easy, and get rich quick. There warn't any gold or silver mines, to fill their money-bags with, nor weak people to be plundered of their wealth, nor rich nations to bo 
spoiled. The only people that were here, were the savage Ingens, that lived in the woods like wolves, and all the property they had to be plundered of, were their bows and arrows. The great forests stood just where they were from the beginnin' of time, stretchin' away and away, hundreds of miles from the sea. Them great forests had to be chopped away, tree by tree, and cleared off, for the growth of grain. That was a mighty labor, Squire, that lay before the airly settlers of this country. Weak men couldn't perform it, and lazy men wouldn't. It was a job that men who loved their ease, and didn't like work, wouldn't undertake. It took stout-hearted men to face that work, and the dangers and hardships of this country, two hundred years ago, and courageous ones too. The tomahawk and the scalpin' knife, were things that had an unpleasant look in timid men's eyes, and they kept out of sight of 'em.

"The men that left their birth-places, and the old homes they loved so well, and swung out on the ocean, to seek on this side of the great waters, a dwellin' place in the wilderness, were strong minded, workin men. They were men of iron frames, and iron const - tutions, and of iron wills too. They were courageous, 
fearless men, who could face danger, and battle with hardships. They were God-fearing men, who brought the Bible and the religion of their fathers with them. They fell to work on the ancient forest trees, and every blow they struck, told them of their own worth. As those old forest trees, that the storm could not bend, nor the whirlwind break, came crashin' and thunderin' to the ground, before the strength of their arms, each one, as it fell, told the story of their power. The acres they cleared, and the crops planted by their hands, as they waved in the summer winds, preached to them of the dignity of human labor, and the value of the men, who could change the wilderness into a fruitful field. As years rolled on, and the fields pushed back the woods further and further, they looked, with a just pride, upon the victory they had gained over nater. The very dangers, and trials, and hardships they had to go throgugh, made them rely upon themselves, trustin' not to kings or princes for protection, but to their own right arms, and the good Providence that watched over 'em. The laws of Old England were well enough for the cities and towns, and thickly-peopled country, but they warn't fitted for the woods and the forests, and the new clearin's of 
America. They wouldn't answer for a country in its infancy, just snatched, as one might say, from the hand of nater, and the hardy settlers had to make new ones for themselves. They went on legislatin' and legislatin' accordin' to their necessities, till at last they learned the great fact, that an honest people could govern themselves, without the aid of kings, and princes, and lords, and sich like expensive contrivances. The skulkin' Ingens made them watchful. Every man had his musket or his rifle, to protect himself and his family agin' the murderin' cusses. He took his fire-arms with him to the field, when he went to labor, and to the church, when he went to meetin'. In this way every man became a soldier, and, while he protected himself, and helped to protect his neighbor, he kept on clearin' away the woods, and pushin' forward the fields, and tillin' the ground, and makin' himself useful, beyond carryin' a gun, and livin' in idleness upon other people's labor. In this way they found out another great fact, that standin' armies were a useless contrivance, and cost more than they were worth. As they went on, they found it neces. sary to have officers to carry out the laws they made, and as every man in the settlements was known, they 
shose their best men as their rulers. They got to gether, and agreed who should be their governors, and sheriffs, and justices of the peace, and constables. In this way they came to the knowledge of yet another great fact, that they could get along best by always choosin' their own rulers. Now, Squire, it was a nateral thing for men, who had swept away the old primeval forests, and spread out broad farms, where before they came, was a great wilderness, when they looked upon the wonderful labor they had performed, I say it was a nateral thing, that they should form a pretty good opinion of themselves, and feel about equal to any king on his throne, or any lazy lord in his palace. When they thought of the savage Ingens they had overcome, the dangers they had passed through, without the aid of the country they came from, it was a nateral thing that they should feel a sturdy independence, that didn't ask any favors of anybody. You see, Squire, how the people who of old built up the government of this country, begun at the bottom, away back at the beginnin'. They learned the great lesson of self-government, of republicanism, from its A B C. They warn't a people that had been ground down by hard task-masters, till their ambition 
and spirit was all gone, and then rose up, only because human nater could bear no more. Their indepen. dence wasn't brought about by a spirit maddened by wrongs, and thirstin' for vengeance, nor did they take up self-government and republicanism, because kings and lords had oppressed them. They began when they were few and weak, and hadn't any great kings or lords to take care of 'em. They were bound together by common necessities and common dangers Their form of government was a thing they couldn't help. They studied republicanism without knowin' it, and because they couldn't help it. They went on, takin' care of themselves and providin' for themselves, till they didn't know or think of any other way of gittin' along at all, and when they got to be great and strong, they couldn't change their habits, and go back. to kingly rule. Their independence was the nateral consequence of their situation, and they were republicans, because, when they first went into the wilder. ness, they couldn't be anything else. They hadn't any king, and there warn't any way of making one, and they got along so well without him, that they found out he warn't of any use any how.

"I'm thinkin', Squire, 'twas a good thing for the 
world, that the seed of our kind of government should have been sown away off in the wilderness, three thou. sand miles from the old kingly governments, where it could take root in a nateral way, and grow up regular, till it got to be strong. If the old kings of Europe had known that there was a young giant over the ocean, sleepin' off here in the forests, and knowd that his joints were knittin', and his bones and muscles growin' in strength, and that he would one day rise up, and snatch the richest jewels from some of their crowns, they'd have taken some considerable pains to strangle him in his cradle. But they didn't know it, and the young giant himself didn't know the strength he was gatherin', and he grew on, till 'twas thought he could be harnessed into servitude. Then he reared himself like a giant, as he was, and defied the world.

"Now, Squire, the people that settled this country were of the kind to push ahead and keep movin'. They did such great and wonderful things in convertin' the wilderness into green fields, that they took up the notion that there warn't anything that they couldn't do. They learned their chi'dren to march on. March on, has been the word for more than two hundred years, and it will be the word for two hun. 
dred years more. This country is young and healthy, with a sound constitution, and hain't got any chronic disease about it, and it can't do anything else but march on. It hain't got its growth yet, by a long shot. It ain't done fillin' up with people, nor spreadin' out sideways either. It will keep on extendin' and extendin, till God only knows where its outside line will finally be. Our people are an ambitious people, proud of their government and their liberty. They've got a way of makin' the people of other countries free, whether they choose to be free or not. If they don't like it, 'tis said to be because they ain't used to it, and. don't know what's for their good. I've a notion that the time will come, when all America will be one great brotherhood of States, livin' under a common government, and the same institutions." 


\section{X V I.}

Mamiprst Distiny. - Yodng Amrrioa on thi Movz.

"WELL," said I, "Tucker, you are making up a pretty extensive government. This bringing a whole continent under a common rule, will be trying a hazardous experiment. Will there be no danger of your great Republic falling to pieces, from its own weight, and will it not be troubled by the discordant elements that you would bring together ?"

"Squire," he replied, "it would take a wiser, and more larned man than me, to argy them pints, so as to make 'em plain to a doubtin' mind. I've a notion they are pints that can't be made very clear by anybody, larned or simple, till the experiment, as you call it, has been tried. I've thought, and studied about the things you speak of, a good deal, and have made up my own mind in regard to them, though, 
may be I couldn't make any body else believe as I do myself, and I don't mean to try. I'm of too little account in the world, to undertake to change things, and so I let 'em move on; but I'll tell you what I think, because you won't say I'm conceited, or laugh at my simple idees.

"The States that made up this government, as I said before, were once very small and weak, and were a great ways apart, considerin' the means people had of gettin' about in them days. They were under different governors and rulers, jist as the different nations on this continent, now are. When trouble came upon them, they united together agin' the strong power of England, and when they broke loose from that power, they agreed to go on together still. The States didn't surrender their independence when they formed the Union. They didn't become one great consolidated government, except so far as the outside world was concerned. In everything that related to other nations, such as makin' treaties, and carryin' on wars, and regulatin' commerce, and sich matters, they were one government. Them things, with a good many other things, concernin' the general welfare, the States surrendered to the general government, hecause they 
couldn't get along any other way. But each State was, for all that, independent of every other State, and of all the other States, and of the general government too, so far as its own particular affairs was concerned. It made its own laws, and elected its own governors, and other officers, without bein' answerable to the general government at all. It was, so far as its own matters, and all that related to the rights of its own people and the management of its own affairs was concerned, just as independent as England, or any other nation in the world. Well, when the Union was thus formed, all the old statesmen of Europe, laughed in their sleeves at the cob-house, they thought the Americans were buildin' up, and they laid their fingers on their noses, and winked at one another, as much as to say, 'see how quick it'll tumble to pieces.' It was a new thing to 'em, and so different from their notions of government, and so onlike anything they'd. ever seen or heard tell of, or read about in books, that they looked to see it go down, in no time. But it didn't go down. It went on prosperin' and growin' stronger and stronger, and multiplyin' and increasin', and spreadin' out in a way that was surprisin' to the wise men of the old world. The thirteen States came to 
be fifteen, or sixteen, and then Louisiana and Florida were taken in, and then 'twas said the Union would go down, sure. 'Twas said by the pretended prophets, that Florida was Spanish, and Louisiana was French, and both were Catholic, and that there would be a disturbance right off. But the Union didn't go down, and there wasn't any disturbance. The fifteen or sixteen States went on increasin' to twenty, and then twentyfive, and so on till Texas came in, and then there was a talk about the cob-house goin' down agin. But it stood up stronger than ever. The United States took a great slice from Mexico, and divided it into territories, and a State, and them thirteen States, have come to be thirty-one, and in two or three years will be thirtyfive, and there hain't been any disturbance among 'em yet, and there's no signs of there bein' any. There ain't a joint weakened, nor any screw loosened that I can see, anywhere. Everthing moves on, just as srnooth and regular, as it did sixty years ago, when there warn't but thirteen States, and four or five millions of people all told. Now, Squire, if them thirteen States could grow to be thirty-one, and double the ter. ritory they had at the beginning, without bein' weak. ened by it, I don't see why the thirty-one can't grow 
to be a hundred States, and spread out to any extent without fallin' to pieces. You see, Squire, the States, though no great things, considered separately, are in. dependent governments, makin' their own laws, and choosin' their own officers, each acting for itself, so far as its own affairs are concerned, without askin', or consultin' any power on airth. But when anything turns up from abroad, they all go together. The gen eral government, backed by the concentrated strength of all the States actin' together as one, is a mighty power, and will be mightier still, as every new State comes into the Union, and outsiders will think twice before they cross its trail. This gives the States a security, and protection from other nations, that they couldn't enjoy out of the Union.

"Suppose Mexico should become a portion of this government, and with her half dozen States, run uF the stars and stripes, what would she lose by it, and what could she find to complain of? Each one of them States, would make its own laws, choose its own governors and judges, and all other officers, and send its own members to Congress. Each would be just as independent as York State is. The general government couldn't and it wouldn't interfere with it, for such inter. 


\section{The ANexAton of Mexico. 263}

ference would be steppin' on the toes of every other State in the Union, and they'd all jine in puttin' a stop to it, about the quickest. Mexico wouldn't lose anything, by coming into the Union. And see what she'd gain. Everybody knows she ain't of much account now, among the nations. She hasn't got any navy to speak of ; and her army, tho' it makes a great deal of noise and disturbance, and a good deal of trouble at home, don't scare anybody on the outside of her. England or France, or any other of the great powers that want anything of Mexico, sends down there a great war. vessel, with cannon looking out of its sides. The captain dickers, and argues, about the matter in hand, while the sailors are polishin' up the big guns, and trainin' them for use. Mexico sees what is goin' on, and takes the hint, and gives in.

"Now bring Mexico into the Union, and I'd liks to know which of the great powers would undertake such a trick as that. I'd like to know, which of 'em would undertake to dictate to her, or tell her what she must do. If a war-vessel was sent down there, Uncle Sam would have one along side of her, and there'd be more polishin' of guns than would be done by the British. They'd find somebody just as sassy, and just 
as ready for a scrimmage, and that could strike just as hard, as themselves, and no mistake. There wouldn't be any struttin' about, and talkin' big, and threatening' to raise cain, generally, and if there was, there would be somebody on the other side, rollin' up their sleeves, and showin' a pretty big bunch of bones, that could hit hard, when blows come to be the order of the day. The States of Mexico could go on, workin' their mines, and improvin' their people, and takin' care of their inside affairs, while the general government would see that nobody troubled them from without. Now, Squire, I don't see why Mexico wouldn't be happier, and more prosperous, and better off every way, inside of the Union, than she is out of it. She'd have her own home legislater, and govern. ment, and an equal voice with the same number of people of New York, in the general government. It's my opinion, when once fairly in, you couldn't drive her out without resortin' to a much greater amount of oppression and wrong, than can be practiced under our form of government. What would be thus true of Mexico, would be true of all the other govern. ments, down to South America. 'Twould be so much to their interest to be inside of the line fence, that it's 
my belief they'd be very glad to stay, when they got into the enclosure. The principles that have kept the States together thus far; that. holds the thirty-one States under a common government, are strong enough, and broad enough, to keep a hundred States together-and that if our form of government will answer for the territory we've got now, it'll answer for all North America, and may be for South America, too."

"Why," said I, "Tucker, you're a 'manifest destiny' man, and go with the 'Young America' party."

"I ain't a politician," he replied, "and don't belong to any party. I make it a pint always to vote, if it's only to keep me in mind that I'm a free man, and entitled to a voice in makin' the officers, and laws by which I'm to be ruled. I've hearn a good many people talk about the country bein' in danger, and the Union unsafe. I never believed a word of it. I've hearn them talk larnedly about the trouble, that might be looked for, from spreadin' out so fast. I never believed a word of that. This country has been spreadin' out, from the time the white man's axe hewed down its first forest tree, and every acre that's been added to it, has made it stronger. So I say the 
country ain't in danger, nor the-Union unsafe, and won't be for two hundred years to come.

"I mind when Gineral Jackson, Old Hickory, as we called him, was runnin' for President, we all went for him in these parts, because he beat the British, and whipped the cussed red-skins. There was a meetin' down to Plattsburgh, and a man came over from Varmount,'to speak to the people. He was a tonguey fellow, and spoke like a book. He talked about the tariff, and the bank, and protection to American labor, and a hundred other things, that he said General Jackson would make a smash of, and wound up by tellin' about this glorious Union bein' in danger, and how it would go to ruin, if the Gineral was elected President, and called upon every honest man to go agin' him. Old Pete Meigs was at the meetin', and I never saw him so riled in my life as he was, to hear the Gineral spoken agin'. When the Varmounter got through, the old man got onto a bench to answer him. He warn't, as you may suppose, any great shakes at speech-makin', and I don't believe he ever tried it on, but that once, but he had a good deal of nateral sense in him, and could shoot pretty near the mark, wher his back was up. 'Look here, 
Mistel.' ne roared, 'didn't Gineral Jackson lick the murder, 1 'Seminoles, and bring the red cusses to their marrow bones, and make them beg like dogs?. Answer rre that.' The Varmounter couldn't get bye givin' in to that. 'Didn't he lick the British,' he went on, 'at New Orleans, and send the red-coats, that he didn't knock on the head, scamperin' home, carryin' their Gineral with 'em in a puncheon of rum ?' This, too, the Varmounter couldn't deny. 'Then,' said old Pete, 'the man that says the country won't be safe, with Old Hickory, who larruped the Ingens, and whipped the British, as President, is a lyin' deceivin' cuss; and now, boys,' he continued, 'all of you that go in for the old soldier, off hats and hurrah for Jackson.' 'Squire, you ought to have hearn the hurrah that followed. May be the house didn't shake much with the shout that went up, and old Pete had to drink more'n once that night, on account of the speech he made. Well, Old Hickory was elected, and the country is safe, and the Union as strong as ever. The truth is, the Union seems to get shaky, and require savin' about as often as the election of President comes round, and it always is saved, somehow or other, no matter which party comes out 
ahead. It has a way of savin' itself, or, may be, it is always saved, because 'twarn't never in danger. I say again, I don't belong to any party, but I vote every year for the men I like best; not to help save the Union, but because I'm proud of the right of votin', and regard it as a duty to exercise it. It's a privilege that poor men don't enjoy in many countries.

"And now, Squire, you spoke of a party called 'Young America.' I never heard the name afore, that I know of, but it is an expressive one, and I suppose it means the party that's in favor of goin' ahead, branchin' out, and of movin' the outside fence further off every way, and, as I heard a man say once, ex. tendin' the area of freedom. Well, a great deal of wrong may be done by such a party, if it's ambitious, and don't stop to inquire about the rights of the coun. tries and people it desires to fence in. If it thinks to go on, because this country is strong, and able to do what it's a mind to, with nations weaker than itself, and to use its strength by forcin' the choice, and com. pellin' the will of its neighbors, then 'Young America' is a hurtful party, and I'm agin' it. But if it's a party that simply means to extend the country, by fair ways, by lettin' all come in that want to, and per 


\section{YOUNG A MERICA.}

suadin' as many as it can to do so, if it's a party that ain't afraid of spreadin' out, and holds to the belief that our form of government is able to sustain the weight and size of all North America, and that seeks by honest means to give it that extent, , ad is willin' tr try what you call the experiment of a government embracin' so much, then it's a good party and I go in for it." 


\section{$X \cdot X$ V I I}

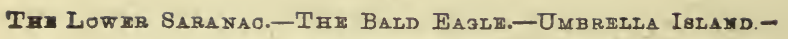
Bati-fach MoUntatn.-Modnt Marot.

THE Lower Saranac is smaller than the Upper Lake, and like it, has several beaîtiful islands. We found no deer, on the one on which we bivouacked that night, but a partridge, and a large gray squirrel, and some fine trout, together with the heavy biscuit procured at the half-breed's, made a comfortable supper. Towards sundown, we saw a long wake in the water, made by something swimming from the shore of the main land towards the island. Its progress was slow, and, whatever it was, was too small and low in the water to be distinctly seen. We watched it, however, until it landed, and it proved to be a gray squirrel that had swam over, perhaps on a visit, to the one we had just made a supper upon. It is no uncommon thing for these little animals, when the lake is calm. 
- to swim to and from these islands. I remember, when I was a boy, to have caught more than one black squirrel, in the crooked lake, that had essayed to swim across it; a distance of nearly or quite a mile; and I have seen many carcasses of those that had been drowned in the effort, and drifted ashore.

In a little bay at the north end of the lake, we spent the night. This bay contains perhaps a hundred acres, and from the beach you look away south, through a narrow opening between the hills, till the view is lost among the clustering islands of this beautiful sheet of water. The morning was still and pleasant, the air genial and bracing, as we started out from the bay towards an island, some three or four miles distant. The lake was placid and calm, and save where the trout leaped from the water, or the wake of our boat, that stretched in a long line of light behind us, on which the morning sunbeams danced, no ripple disturbed its surface. On a dry tree, that stood on one of the points that stretched lakeward, forming the little bay, sat a bald eagle. I hoped to get near enough to bring him down with my rifle; but his keen eye was wide open, and before I got withiu sbooting distance, he leaped upward from his perch. 
stretched his broad wings, and soared majestically away. Nearest the foot of the lake, and just outside the bay, are two beautiful islands, called The Sisters. They contain perhaps an acre each, and are covered with a thick growth of evergreens.

As we rowed along up the lake, we trailed a long line behind us, trolling for the lake-trout. At length the bait was seized by what, to me, was a monster fish, and I reeled him in on a line of a hundred and fifty feet. He struggled and floundered, and leaped from the water, and dove again for the bottom,-went skiving away to the right and left, in his hard battle for life,--but the hook was in his jaw, and after a fight of nearly half an hour, he lay exhausted in the boat, a lake-trout of five pounds in weight. This is not the season for trolling, and we caught no more in this way. In the middle of the lake rises a barren rock, standing all alone, treeless and shrubless, lifting its bare head some twenty or thirty feet from the water.

Off to the right, and at a quarter of a mile distant, is Umbrella Island, which takes its name from a singular tree standing near its centre. This island is covered with low green trees, but from the midst of which shoots up a tall pine, its trunk straight and bare, some 
fifty feet above the surrounding foliage, and then spreads out in a broad evergrecn tuft, like an umbrella. This curious tree may be seen for miles, standing there solitary and alone, like a giant amoug pigmies, and, not inaptly, gives a cognomen to the little island above which it towers.

Away off to the north-east, miles and miles away, the mountain peaks are seen, moveless and solemn, like vast pillars sustaining the sky. Conspicuous and tallest among them is the Ball-face Mountain. This gigantic peak seems to be everywhere present. You see it from Keeseville, seemingly between you and the Saranacs. You see it from "The Forks," twelve miles up the Au Sable, apparently in the same place and at about the same distance. It is before you still, when you cross the high table land, ten miles further on. It looks down upon you from the Franklin Falls, another ten miles further west. It is in plain sight here, five and twenty miles west again. You see it as you are floating on Tupper's Lake, still another thirty miles west, and you rejoice that you have weathered the giant, that seems to be watching you all the long day. This lofty peak goes up from a range of mountains, which lays between the sources of the Saranao 
and those of the Au Sable, further north and west than the Adirondacks proper. Beyond this range lay the Adirondacks, and dim and shadowy, looming darkly in the haze, are seen Mount Marcy, Mount Seward, and other less notable peaks. These stand away off behind the ridge spoken of, like tall grenadiers, looking over the front ranks of small combatants, overtopping all, save the tall old "white-faced" commander. He stands out always, like Saul among the prophets, from his shoulders upward, taller than his fellows. On one of the islands we found a deer, which Shack coursed at his best speed, twice around the island. The third heat it took to the water, and we put out in our canoe after it, but on overtaking it, we found it to be a doe, the lean condition of which, indicated that it had a fawn to provide for, and we left it unharmed, and turned back. The animal seemed glad enough to part company with us, and we saw it look back as it ascended the bank on the main land, as if saying, that our absence was vastly more agreeable than our company.

In the afternoon, having drawn our canoe from - the water, and concealed it in a thicket, we bid good bye to the Saranac lakes, and struck off north-west, 
towards Coleby's Pond, or Lake. This lake is some tivo or three miles distant from the Lower Saranac. We found a canoe at the head of a little bay that extended landward, beneath the branches of some old elms that formed a green arch over the water, shutting out the sun-light, and making an arbor as delightfully cool and sweet, as the imagination can conceive. These little bays, are the most beautiful spots in nature. There is a romantic sort of pleasure in letting the water-craft, in which you are seated, float away into one of them, in the heat of the day, and beneath the branches of the brave old trees, whose spreading arms and clustering foliage give you a shade that a Houri might envy, light your segar, and give yourself up to the luxury of repose.

In the night, we shot a fine young deer. as he was feeding in the water. This pond, or lake, is some three or four miles in circumference, and, like all the other lakes in this region, abounds in trout. The weather continuing exceedingly warm and sultry, we felt in no hurry to leave this beantiful sheet of water. It was the last of the series, and we resolved to remain quiet, for a day or two, and as Tucker expressed it, take things easy. 
"I've been thinkin', Squire," said he, "twould bo a pleasant thing, for you city people, to spend one of the hot months, every season, off here among these lakes and mountains, in a quiet way, huntin' and fishin,' and lookin' about just enough to keep nater a goin'; sleepin' on green boughs at night, and sweatin' among the hills in the day time. There's no pestilence in the pure air of this region, and a few weeks out here in the woods, would drive out all the seeds of disease, planted in the system by the foul atmosphere of the cities. 'Twould drive away that sallow paleness, from the faces of your young men, and make 'em strong. People keep good hours, in the woods. They go to roost with the birds, when the darkness comes down, and they're up as soon as the stars go out, and they see the sun rise in the mornin'. They ain't spendin' their nights at the theatres, and clubs, drinkin' cold punch, and smokin' cigars, and doin' a hundred other things that bring on old age afore its time, instead of Iayin' themselves quietly away to rest; and then they don't swelter all night in the bad air of a close room, that the morning breeze never looks into, and their lungs ain't poisoned by the smoke and vapor of ten thousand cookin' stoves, and forges, and machine. 
shops, and gas fixens, and sich contrivances. There's no crowded rooms off here in the woods, and the air a man breathes at night, hain't been breathed already, by his neighbor in the next bed. It's a big 'sleer in' room, we've got out here. Its rafters rest on the peaks of the mountains, the sky is its coverin', and the curtains are all spangled over with stars. It's open all round. The fresh breeze of the mornin', fans the face of the sleeper, and he gets a taste of all the pure air that's goin.' We ain't pisoned by the cookery, and don't stuff ourselves beyond nater with rich food. We eat when we're hungry, and what we eat we catch, ourselves. We ain't troubled with dispepsy, and wild game don't hurt us. Now, Squire, I've a notion that a month spent among these lakes and streams is worth more to an ailin' man, than a dozen of doctors, and a bushel of pills.

"I mind, once, five or six years ago, a man came up from Philadelphy, and wanted, as he said, to get into the woods, so as to be out of the way of the doctors. He looked gaunt and lean enough, and his bones stuck out, like an old buck's, at the end of a hard winter. His food troubled him, and he didn't relish it, either. His sleep troubled him, and he 
didn't get an overstock of that:- Well, he stayed around Plattsburgh two or three days; and happenin' to hear me, one day, when I was down there, tellin' about the Shatagee Lakes, he hired me to go with him for a week. We went over to the Shazee first, and and lived there for a week, on venison and trout, and such fixens as we took along. At the end of that time, he began to feel like a new man, and he sent me back, for another packload of biscuit and pork. We went over to Bradley's Lake, and so down to the Shatagee. $\dot{W}$ e visited Ragged Lake, and Ingen Lake, and cruised about for a month. He growed better and smarter, every day. His strength kept a comin', and his lean cheeks filled up, and his eyes lost their sickly look, and he came out a new man. He'd gained mor'n thirty pounds of flesh. He could digest a brick-bat, and what he eat warn't never heard of again. He paid me as a guide and then doubled my fee as a doctor. He said my medicine was the cheapest, and best he ever took. 'Twas the pure air of the mountains, and stirrin' about, and sweaten', and sleeping on hemlock boughs, and goin' to bed airly, and gettin' up airly, and washin' and swimmin: in the cool water night and mornin,' and huntin' and 
tishin'. This was my medicine, and the best of it was, there wasn't anything onpleasant, in the takin' of it. Now Squire, I say again, this kind of medicine is better for an ailin' man, or one that ain't ailin', than all the poticary stuff in creation, and 'I wonder that more people who live in the crowded cities, don't try it. I've a notion 'twould be specially good for lawyers and scholars, and ministers, who sit.in their offices studyin' and writin', or in the crowded courts, breathin' the bad air, and swelterin' in heated rooms; 'twould make their heads clearer, and their bodies stronger; 'twould save them from, a deal of bad feelin's, and keep them from bein' poisoned, by the doctors. But 'tain't no use to preach this doctrine, to people raised in the cities. They're in such a hurry to make money, to push ahead and get rich, and have so many irons in the fire, that they've no time to spend off in the woods, alone with nater, or in takin' care of their bodies. Besides, half of .'em, don't know anything about what's outside the corporation. They never saw a lake, and think the woods is full of rattlesnakes, to bite 'em, and painters and wolves to devour them, or Ingens to scalp 'em, and that if they get outside of the clearins', they're done for, sure. All that, is a 
great folly, Squire, and their pale faces and gray hairs, that come before their time, ought to tell 'em so.

"And yet, it was a wonderful wisdom, Squire, that made such a great difference in the likes, and dislikes of men. -If everybody in the world was like you and me, and loved the woods, and to be away off in the deep forests, there wouldn't be much game left in these parts, or a great many fishes, in these lakes and streams. The hills and valleys, would swarm with people, and there wouldn't be much elbow room, for you and me. I, may be, meet a man who lives in in a city, or great town, who hasn't got any likin' for the back settlements, or no taste for the woods, who never looks at land, unless to find out what it's worth by the acre, whose estimation of a mountain stream, is regulated by the amount of machinery it'll carry, and whose regard for a lake, is measured by the prospect of converting it into a millpond. Now, such a man wouldn't leave nater, anywhere, one of the nateral features of her old-fashioned face. He wouldn't leave a deer in the forest, nor a trout in all the streams. He'd convert the old trees into cordwood, and these narrow valleys into sheep pastures. He'd lay up these boulders into fences, or pile them up like hay-stacks. 
He calculates that time is money, and spendin' a few days among these hills and lakes, he'd regard as a reckless waste, like the waste of a man who spends his dollars in card-playin', horse-racin,' cock-fightin', and drinkin,' and spreein' them away. He wouldn't enjoy himself here at all, because his heart wouldn't be among the hills and lakes. Well, may be, he looks at me, and wonders that I don't seem onhappy and sorrowful, away off here, on what he regards as the outside of creation, and, may be, pities my forlorn condition. He wonders how I can content myself in this region, where there ain't any paved streets, and carriages, and carts, and stores, and fine houses, and thousands of people. He thinks in his heart, I'm a poor ignorant creeter, and that my lot in life is a hard one. Well, he's right enough in thiıkin' I'm poor and ignorant, but if he'd give me his fine house and his carriage, and all his rich goods, and ask me to live cooped up in the city, listenin' to the dull sounds that come up from the streets and the work-shops, and all the other manufactories of noises, and breathin' the stenches, and foul air, that comes up from the filthy places, everywhere around him, I wouldn't look at it. My lot in life ain't half as hard as his, and I'd tell him so. I'm a 
free man, I'm no slave to business, nor to wealth, nor to the customs of the world around me. I've got all I want to make me comfortable, accordin' to my notions of comfort. I've got a wife that sticks by me, and children that loves me, tho' they don't make any fuss over me, nor any parade of their feelin's.

"I've got my rifle, and a canoe on most all of these lakes, and I've got an honest dog to go with me. I go where I please, and when I please. When I take to the woods, I've no business to suffer while I'm gone, nor distress my mind, while I'm away in the forest. You see, Squire, my lot ain't a hard one, as I understand it, and if it suits me nobody need com. plain. I've hearn it said, that it takes all kunds of people to make up a world, and I believe it. If a rich man is happy in his wealth, I don't envy him. It's his way. If a great man is happy in his greatness, l don't envy him. It's his way too. Such people may stand on one edge of society; somebody is needed on the other, to make things balance, and I'm content to be that man. Every man's lot, Squire, is hard or easy, accordin' as he himself understands it. A man can be happy and enjoy life, without bein' rich, or wise, or high in office. Wealth is a good thing for 
them that desire it. Wisdom is a great thing, too, but for all that, rich men and wise men ain't always happy men, nor their lot in life the easiest. Now I' $m$ rich, berause I'm contented with what I've got. I'm rich for another reason. I live just as I want to live, and just as I like to. My way of livin' suits me, and all the wealth of the world, and all the larnin' of the schools, wouldn't better my condition, or make me any happier by day, nor sleep any better at night. Never pity a poor man, Squire, who isn't hungry or cold, and is contented with his lot. That's pity thrown away. It does nobody any good. I've been around among poor people a good deal,-_not the poor, and the ragged, and starvin' people, that live like pigs, huddled together and mixed up in dirty rooms, and. in the filthy streets of the cities, but the poor people of the back settlements of the new country, and let me say to you, Squire, them hard-workin' people ain't objects of pity. They enjoy life as much, and are as happy, accordin' to their ways, as the richest man in the cities, or the wisest man either. They laugh, and sing, and joke, and are as merry as the best. If their food ain't as rich and dainty as yourn, they've a botter 
appetite for it, and that makes up the difference. If their clothes ain't as fine as yourn, it keeps them warm, and that's all the rich man's can do. They sleep better at night, because they've got no cares to trouble 'em, and they don't get up with a head-ache in the morning, on account of dyspepsy, for their labor keeps up digestion.

"Don't understand me, Squire, as believin' that riches, and larnin' and wisdom ain't to be sought after, nor that everybody should be like the people of the back seftlements I've been speakin' about. I wouldn't have everybody like me either. The world would be in a bad fix, if it was so. I'd have everybody ge ahead, everywhere. I'd have all the world try to become wise, and larned, and rich, and be polished and genteel, and I'd push good society as far towards the back settlements as I could, or as the fitness of things would allow. I send my children to school, and tell 'em to get all the larnin' they can, and be wiser, and better, and have more property than their father ever had. But, as I said afore, it takes all sorts of people to make up a world. You've got your place in it, and I've got mine, and I'm goin' to stay where I am, be- 
sause I like it, though I own I'd like to see my chilMren a step or two above me, and, if I lived long snough. to see their children a step or two above thern. 'That's my idee of progress." 


\section{XXVIII.}

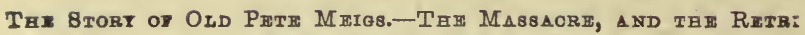
BUTION THAT FOLLOWED.

"I saID the other day," said Tucker, "I'd tell you afore we got home, the story of old Pete Meigs' early life, and I'll do it now. It wasn't a thing he liked to talk about, and he never spoke of it to me but once. I said the other day, he was a strange and solitary man, and a gloomy one sometimes. He had places in the woods he always seemed to like better than anywhere else, and the St. Regis Lake was one of 'em. He would stay round there for days and weeks, and he seemed to look on it as his home in the summer months. It was one day, while we were paddlin' along the shore, round the base of the steep hill, that he told me the story of his young days, and the things that hung like a dark shadow and a desolation over 
his whole life, that made him onlike other folks, a solitary and a lonely man :

"'I was born,' said he, 'in the Mohawk country, and I remember well my father's log house and clearin', was back of the other clearins', along the valley of a stream that came down from the hills. It was about the close of the Ingen war, and a dangerous place to live, tho' my father didn't think so. I remember my mother was a Christian woman, and my two little sisters and brother, all younger than myself, we'd sit around her of an evening, and hear her read the Bible by the light of a fatwood knot on the hearth, and we'd all sing the simple hymns that we knowed, and then she'd kneel down, and pray for us, to the great God that hears the prayers of his people, even in the deep forests, and away in the lone woods. We were a happy family then, all alone there by ourselves, and I loved my father and mother, and those little sisters and brother, the more because we were so alone, and as I have never loved, and never can love anything else. It's a sad thing to think that they all passed away, in their brightness, and beauty, and strength, all at once, to become victims to the tomahawk and scalping-knives of the Ingens, and 
their bodies burned in the flames of their own home.

" I was fifteen years old then, and a strong, knowing boy, for my years. I'd been down one day to the Mohawk for the doctor, for my father was sick. I had to go five miles on foot to reach him, 'but he was sick, too, and couldn't go. He gave me some medicine for my father, and I started back. It was a while after dark when I came in sight of our clearin'. I didn't go the road, but followed a footpath across the woods. When I came to the stream, and was crossin' it on a log, I saw the forms of men standin' in the darkness round the house, and knew they were Ingens, and my heart sunk within me, for I knew they were there for no good. I hid away in a thick bunch of bushes, where I could see the house, for I was afraid to go further. I had no weapon, and if murder was their object, God help my parents and their little ones, for I could do them no good. All at once the door was burst open, the savages screamed their terrible war cry, and I saw them rush in like devils. I heard the screams of my little sisters, and a wild shriek from my mother. A great cloud seemed 
to come down all around me, my senses left me, and I becarne like one that is dead.

" "When I came to myself, I saw the flames of my father's house going up towards the sky, lightin' our clearin' and the woods around, like the day. I saw the savages dancin' and yellin' ruund the burnin' cabin ; and I saw on a pole, held by one of them, the rcekin' scalps of my whole kindred,- the black hair of my father, the long tresses of my mother, and the silken locks of my little sisters and brother,-all were there. There was a strange feelin' of calm, intense desolation upon me. My senses were all awake as they'd never been before; I was without hope, as I was without fear ; I seemed to be another and a new being. No mist was before my eyes; I could look, as it seemed to me, through the war-paint on the faces of the Ingens, and their wild contortions, and see their features, as if they'd been familiar to me for years. I seemed to know 'em all, like I knew people I'd been with every day, though I'd never seen one of 'em be fore. I could pick'em out among a thousand, and n disguise of war-paint could prevent my knowin' 'em again. There was eight of 'em, and the one that carried the pole with the bloody scalps, was taller, nearly. 


\section{HILLS AND LAKES.}

- by a head, than the rest. His arms were long, almost like an ape's, and one of 'em seemed stiff at the elbow, as if from an old hurt. I counted 'em where I lay in the bushes, over and over again, as they danced a horrible dance round that burnin' pile. I warn't angry, nor sorrowful, nor afraid. A strange sort of calmness was on me. I seemed to look on without any thought, but to study the faces and forms of them Ingens ; why, I know not My feelins' seemed to be all dead. I forgot father, mother, brother, sisters ; all passed from me, while I looked upon those bloody scalps, and studied the faces of them red demons dancin' round.

"'After awhile they gave one last horrible yell, and filed off, one after another, towards the forest. They passed close to the bush beneath which I lay. He with the scalps went first, and the rest in a line behind him. I saw all their faces, plain and distinct, as I see yours. They all seemed to look straight at me, as they'passed by, and moved away into the still woods. Then a lrowsiness, heavy, like death, came over me, and I so.nk away into a deep sleep.

" 'When I awoke, the sun' was shining. I looked out from the bush, and saw the neighbors standin' round, and wondered why they were all there. I 


\section{THE DESOLATION.}

looked for my father's log-house, and saw a heap of smokin' ruins where it had stood. I came out from my hidin' place, and stood among the people, and heard them talkin', as if I was in a dream. Presently memory came back to me by slow degrees, and when I thought of all I'd seen, a sorrow, almost greater than human sorrow, came over me. I could not weep. My eyes refused to shed tears. My tongue would not speak, and I shrieked aloud in mý great grief, like one whose senses are gone. The neighbors gathered around, and spoke kindly to me; and one old man, I remember, put his arm gently around me, and led me to the little spring, and as he set me down on the green grass, dipped his hand in the cold water, and passed it. over my burnin' temples. He sat down beside me, and, drew me gently to his bosom. 1 seemed to think it was my mother that I leaned against, and tears gushed from my eyes, like a fountain from beneath a roek. This revived me, and I told them all I'd seen. Ten stout men, with rifles, started on the trail of the Ingens, into the deep woods, vowing vengeanee against the murderers.

“' I stood-by the smoulderin' ruins, while they were removed from above the burned bodies of my 
only kindred. There lay my father and mother, my little brother and sisters, a shapeless mass, in the midst of the desolation. They buried them without a coffin; and all that I had ever loved, all the kindred I ever knew, lay together, beneath a little mound raised over them, by the kind hands of the settlers from the River Bottoms. I went with them, a desolate-hearted and sorrowful boy. I had nobody to love, nobody to live for. My father and mother, brother, and little sisters, all were gone, and I was alone. The neighbors were all kind to me, and I was among them as one of their own, wherever I chose to go ; but for all that I was alone. The voices that I loved were all gone, the faces that I loved were all gone, and everything round which my heart clung, had passed away. I went with the old man that bathed my temples at the spring that morning, and my home was for a time with him. I said I was a strong, hearty boy of my years. I worked for him, late and early. I was up before the sun in the morning, and was by the side of full-grown men, doin' the work of a man, all the day. I had but one desire, and that was a deep, restless, consumin' thirst for vengeance-but one hope, and that was of the bloody destruction of those who had 
made life a desolation to me. I wanted a rifle, and a knowledge of the use of it.

" "Well, at last I had earned money enough to buy one, and a good one it was, too. I carried it for five and twenty years, and 'twas because I lost it, by accident, in the deep water, in the Saranac, that I don't carry it now. When I became the owner of a rifle, I worked on to procure other things needful to a hunter, and then I gave up work, and took to the woods. I spent days and weeks in the forest, studyin' nater, and the ways of wild animals, and the forest signs, and followin' the trails of wild beasts. I studied to larn, as boys at school study books. I wanted to become wiser in the forest ways than the Ingens were. I longed, with a burnin' longin', for vengeance on their accursed tribes. It was my whole thought, and aim, and object, in life. The war had passed away. The Government was at peace with the Ingens, but my war with them had not yet begun. I was young, scarce yet nineteen, and the years of my life were to be one long, undyin' warfare against 'em. The faces of them eight Ingens, that danced around our burnin' dwellin', on that horrible night, were always before me. I could have picked them out from 
294. HILLS AND LAKES.

among a million. Every night, I saw them in my dreams, and every day they grew more distinet, until they seemed to be before me bodily, and I saw them as plain as I see you before me now, and I felt I could never rest till I'd hunted 'em out, and slain 'em.

" "I told you that on the-morning after the murder of my kindred, ten of the settlers followed the trail. They were gone five days. The Ingens had taken to the water at Lake George, and further pursuit was useless. Then we knew they belonged toward the St. Lawrence, of the tribes below the Lower Shatagee.

" 'Five-years after the murder of niy poop!e I started for Lake Champlain. I passed up Lake George, and so on, up Lake Champlain, to above Rouse's Point, and then took to the woods. I built a shantee on the Shatagee river, and stayed round there for a fortnight. I was one day standin' on the brow of a hill, lookin' out upon the forest, when I saw at a distance from me, a blue smoke, curlin' up from among the trees. I knew 'twas an Ingen camp, and all my thirst for vengeance was strong upon me. I crept like a painter, to within sight of their camp. Two hunters sat by the fire smokin' their stone pipes. 'Twas near sundown, and I knew there were no more 
to come in. The carcasses of iwo deer hung upon trees by their camp fire, and long strings of jerked venison hung upon poles around. I crept closer still, and as one of them rose to his feet, and turned towards me, there stood that long-armed, gigantic Ingen, that danced round my father's dwellin', as the flames were consumin' it, carryin' aloft the reekin' scalps of my murdered kindrer. In the other, as I got sight of his face, I saw another of the eight, whose face had been with me always since that horrible night. You can't think how great my joy was, when I saw them there before me. I watched 'em, and glared upon 'em, and gloated over 'em, as the tiger watches and glares upon his prey, from his secret hidin' place. Worlds would not have purchased their safety. I would have spurned heaps of gold, if offered for their lives, and the prayers of all the good men in the world, wouldn't have saved them from my fury. They were mine, mine for destruction, as a feast for my vengeance. I was like a starvin' panther, a hungry and whelp-robbed bear. I lay there till night came on, and they slept. I crept to where they lay, and removed their rifles. I stole their huntin' knives from their sheaths, and threw them to a distance. They had gorged them- 
selves with food, and slept soundly. I heaped knots upon the fire, and it flamed up into a bright blaze. Then I stepped back, and shouted. They sprang to their feet, and looked round for their rifles. They were gone, and there I stood before them with my gun poised. "Dogs, wolves, (I shouted in their own tongue, for I'd learned it when a boy,) murderers of my kindred, die like dogs and wolves." One of 'em fell dead at the crack of my rifle. It was the snialler one. The other turned to fly, but I was upon him in - an instant. The strength of a hundred men was in me. I hurled him to the earth. My grasp was upon his throat, my knee upon his chest. Strong as he was, he was like an infant in the grasp of a furious man. I used no weapon in his destruction. I literally strangled him with my hands. It seemed to me that to use a rifle or a knife upon him, would be allowin' him a death too noble. I left their carcasses where I slew them, a prey for the wolves and the carrion hirds.

" "With their death, my desire for the blood of the others of them eight, seemed, if possible, to increase. Nay, their destruction would not appease the fierce thirst for vengeance that was in me. I wanted to 


\section{The Consumation of Revenge. 297}

annihilate the whole tribe, even the race itself, as one great offerin' to the murdered kindred that I loved so - dearly.

" 'On the St. Regis River, away up towards its source, I saw one day a smoke goin' up to the clouds. I crept within sight of it in the night time, and saw five Ingens stretched before the fire; I could have slain them as they lay, but would not. I felt a strange desire to cut them off in detail. To slay them there at once, would be too brief a vengeance. I watched them till morning. One of 'em shouldered his rifle, and started off in a direction towards the St. Lawrence. I followed him stealthily for two or three miles. He stopped to look round him, as I broke a dry limb purposely to attract his notice. That was the first look of his face I got, and he was one of the eight. It was an open wood where we were, and there we stood, facing each other in the forest. The shriek of my mother seemed to ring in my ears again, as I raised my rifle. As the report broke upon the stillness of the woods, the Ingen leaped into the air, and fell to the earth dead. I left him there where he fell. Of them five Ingens, not one returned to his tribe. Three of them were of the eight that danced around the 
flames of my home, and yelled, while my kindred's bodies were consumin'. I needn't tell you more.

" ' Joe,' said the old man, as he sunk his head down between his hands, 'of them eight Ingens that I counted that night, not one sleeps with his tribe, and may be the bones of a good many more lay scattered about in the Shatagee country. 'Twas a wrong thing, as I look upon it now, and I'm sorry I slew 'em. But I was mad then. The murder of my family made me crazy in my hatred of the Ingens, and I thought I heard the spirits of those I loved callin' to me for vengeance. That cloud has passed away from my heart now, and if I could undo what I've done, I'd gladly do it. 'But it's too late.'

"The old man sat silent for a long time, with his head leanin' forward, and his face concealed in the palms of his hands; I saw the tears fall in big drops from between his fingers. I did not disturb him, for I saw memory was busy with him. I thought may be his heart was away to his boyhood's home, that his mother was readin' to him from the good book, and his little brother, and flaxen-haired, soft-voiced sisters, were around him. It's a sorrowful thing, Squire, to see a strong man weep; to see his iron frame throwin' 


$$
\text { Past A t T tons. }
$$

off tears like a woman. It's a great grief that can wring great drops of tears from the eyes of a stouthearted man, when he thinks of the things he's passed through on the trail of life.

"I paddled quietly to our landin'-place, and stepped ashore. The old man rose up, and walked slowly and sorrowfully to the shantee, and laid down - on the green boughs, and turned his face away, and sobbed like a child. Like a child, too, he sobbed himself to sleep, and lay quietly till daylight. He rose up a sad man that morning. The cloud at length passed away from his spirit, but we never spoke again about the massacre of his kindred, or the vengeance he took upon their murderers." 


\section{XXIX.}

A Dematci.-Thi Virmontrr and his Lickiog-Shootina tha Wrong ANTuAt.

WE shot into the expanded mouth of a stream that formed the main inlet to the lake. -Here we landed, and followed a path along the bank of a muddy little rivulet, some quarter of a mile, till we came to a little basin, scooped out by the hand of nature in the side of the hill. In this basin we found the spring from which the streamlet originated. Its waters had an unpleasant, brackish, mineral taste, and the mire out of which it oozed, was trodden as if a flock of sheep had been passing through it. Little paths led away from it in every direction into the forest. It was what is termed in border parlance, a "deerlick." Here the deer came in the night to lap its brackish waters, and stamp round in the mud. It seemed to be greatly frequented, as the paths and thousands of 
tracks indicated. It is one of the ways of taking the deer, near the settlements, where they are scarce, and hard to come at, to watch one of these "licks" at night, and shoot them as they come in to taste the waters. The hunter makes a "blind" of boughs, placed in a natural kind of way, thick enough to conceal him, and yet. so arranged as not to attract the notice of, or alarm the deer. - Behind these he places himself, with his rifle protruded through an opening among the boughs, large enough to admit of his taking aim along the barrel, but not so large as to expose his face to the view of the game. He is provided with a little torch of fatwood shavings, which will readily ignite from a match, and blaze up so as to make a flame of the size of a gas-light. This is so arranged, that the light will fall upon the deer as he stands in the "lick." The hunter takes his position behind his blind about sundown, arranges his rifle, and his little torch ready for ignition, and sits quietly waiting for the deer to "come in." In the early part of the evening a deer will be heard treading softly among the leaves, and walking carefully towards " the lick." Sometimes he scents the hunter, and stops and listens. If he suspects danger, he will stand whistling: and 
stamping, as if endeavoring to call out his hidden fue. If the hunter lays quiet, in the course of a quarter or half an hour, the deer will overcome his fears, or conclude there is no danger, and walk into the lick. A match is cautiously applied to the torch, and as it blazes up, he raises his head with a start, cocks his tail, and gazes with astonishment on the light. Sometimes he will make a bound or two and. stop, to examine the strange fire thus suddenly kindled before him. Then is the hunter's time. There must be no rustling of leaves, no breaking of dry twigs, or the deer will plunge snorting and whistling away into the forest, leaving him to his meditations, and the musquitos and black flies, till morning, or a dark walk in the woods home. If he is careful, his game is so near, that his shot will be sure and fatal.

There is one great drawback to this kind of sport. The musquito and black fly swarm round the hunter, stinging and biting him almost. beyond endurance. He can have no smudge. He cannot stir, to fight them away while the deer is making up his mind whether to "come in," or run away. He can only lay still and bear the infliction "with what fortitude he may." Half an hour of such torment is poorly re- 
paid by the death of a deer. I have tried it once, and though I endured it to the end, and secured my game, yet that one trial satisfied me. I have never "watched a deerlick" since, and am very sure I shall never watch one hereafter. A man whose skin is thinner than that of the rhinoceros, if he follows my advice, will not wait for a deer at a "lick" in the Shatagee country.

"I mind," said my guide, as we paddled back to our shantee, "a thing that happened down to the settlements, to a young feller that worked for a man there, one summer, four or five years ago, that made a deal of fun among the neighbors for a long time. They called him Gabe Calvin, and he was a long, slabsided, strappin' youth, from Old Varmount. He was always talkin' ubout the things he'd seen on the Green Mountains, and from his tell he was the greatest hunter this side of anywhere. The painters, and catamounts, and bears, he'd seen, was amazin', and you'd a believed that them varmints were thicker where he came from than gray rabbits in the Shatagee Woods. He'd hear'n tell of deerlicks, and how they were sometimes made. So he started out one Sunday into the woods, with a bag of salt and an auger. $\mathrm{He}$ 
found an old $\log$, rotten like on the outside, such as he'd hear'n tell was the right thing, and he bored it full of holes, and put in his salt. That isn't a bad way, Squire, to make a deerlick, for if the deer find it, as they'll be pretty sure to do if there's many about, they'd work at the salt till they've eat up half the log. The next Sunday Gabe visited his_lick, and sure enough the wood was all gnawed away round the auger-holes, and he reckoned he'd have a tall time with the deer that had done it. So he built him a blind, cute as anything, and got things ready to make a general smash of all the game in them parts. He put more salt on the logs, and bored new holes, and filled 'em, and when he came back he told about seein' deers' tracks as big as two-year-olds.

"The man he lived with had an old Queen Anne's piece, long as a liberty-pole, with a bore you could stick your fist in. It had been through two or three wars, to say nothing about scrimmages with the Ingens. 'Twas old and rusty enough to draw a pension, and hadn't spoke, may be, since the last war. It hung up on pegs in the farmer's stoop, and had hung there ever since he'd been in them parts. The old man that owned it, kept it, as he said, as a kind of 
scarecrow to the British-a sort of notice that 'twas an onhealthy climate for 'em about there.

"Well, Gabe got down the old musket, and scoured it up, and cleaned out its insides, and put in a new flint, and iled up the lock so 'twould go, and then loaded it about half full of powder, and buckshot, and slugs, and sich destructives, and started about sundown with his match and little torch, to watch his deerlick, and raise thunder generally with his big buck, that made a track like a two-year-old. He got behind his blind, and poked the long barrel of his old Queen Anner through the brush, and laid,down behind it with the breech to his shoulder, waitin' for the game. The musquitos poked their long bills into him, and the black flies gnawed away at his face and bare legs, in a way that made him kick and thrash about like a horse tormented by a million of gadflies. "By-and-bye, after the dark had come down, Gabe heard somethin' walkin' towards his lick, and his heart beat like a trip-hammer against his sides, and he lay still, lettin' the musquitos and flies bite him, and be darned. Presently, whatever it was he heard walkin' in the bush, stepped up to the $\log$, and began to lick at the salt, and gnaw the old wood in earnest, 
as if it had found something good. Gabe lighted his match, and held it cautiously to his shavins of fatwood, and as they blazed up, he sighted along the barrel, shut up both eyes, and blazed away too. The charge from the old musket went one way, and Gabe went the other. The old Continentaller kickin' him worse than a whole team of horses, and the roar that was heard in them woods, and went echoin' about the hills, and bellerin' among the mountains, gave the wild things around fits. Gabe rolled over and over down the bank, and brought up in a muddy pool, with his shoulder half-broke, and his cheek bruised as if somebody had struck him with a sledge-hammer. The folks at home, hearin' the report, concluded they'd have venison enough for a week, and no mistake. About ten o'clock Gabe came creepin' along home. He hung up his old musket, and stole off to bed in the dark. He didn't answer any questions very distinctly, and when he crawled out in the morning, sich another lookin' animal couldn't be found in the Shatagee country. One eye was swelled tight, and his face was all on one side, and his shoulder was blue all over as an indigo bag. He didn't say much about his deerlick, or what he'd let off old Queen Anne at, 


\section{The Mistake.}

307

but the next night one of the farmer's yearlins was missin'. They found it layin' by Gabe's licklog, with about twenty holes clean through it. Gabe didn't stay about there long. He heard too much about his great shot, down at his deerlick, and his big buck, that made a track like a two-year-old." 


\section{X X.}

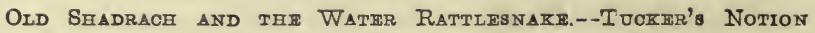
OF Siaviry. - ThE END OF that Inetitution at Last.

AfTER our return to our shantee in the evening, and after we had supped, I told Tucker an anecdote, concerning an old negro who belonged to my father when I was a boy, and when slavery existed in this State. I repeat it here, only by way of introduction to one of Tucker's peculiar discourses upon a subject which had engaged his attention, and upon which he had evidently bestowed some reflection.

My father had become security for a friend, in the loan of money, and to indemnify himself against loss, had taken a mortgage upon a negro. The debt fell upon my father, and he became the owner of a man. Old Shadrach was a Virginian by nurture, but an Ethiopian by birth. He was transferred in a slaveship from the jungles of Africa. when a small boy, to 
enjoy the luxuries of civilization in the Old Colony, or as much of them as was compatible with his condition as a chattel. He was brought to Steuben, by an Virginian, who came there with a large number of slaves and plethoric money-bags, to run through all the gradations, from respectability to absolute destitution, and to die at last a pauper, and be buried at the public expense.

Old Shadrach stood in mortal fear of snakes and toads, and could be frightened into any measure, by the threat of having one of these put in his bed. $\mathrm{He}$ ran away regularly two or three times every year, and would stay away sometimes a fortnight, sometimes a inonth, and on two or three occasions. he was gone so long, that my father began to congratulate himself upon being rid of him entirely. But some morning, Old Shadrach would come crawling out from the haymow, and promise his master solemnly to be obedient and industrious, and never run away again as long as he lived. I said he stood in mortal fear of snakes. He was one day in a canoe, out fishing on the Crooked Lake, on the bank of which my father's house stood, and drew up what he took to be a rattlesnake. He dropped his pole in a perfect horror of affright, and 


\section{HILLS AND LAKES}

leaped overboard, roaring for help, as if all the wild animals and poisonous serpents of his native jungles swere after him. He could swim like a duck, and he struck out for the shore, screaming with horror at every pull. Upon reaching the shore, he broke like a quarter horse for the house. My father, who was at a short distance, hurried up to know the reason of the outcry. "Massa!" cried Shadrach, in all the earnestness of terror, "de lake is full of rattlesnakes!" "Get out, you woolly-pated rhinoceros," replied my father; "who ever heard of rattlesnakes in the water?" "Golla! massa !" replied the African, "he dere now, sure." My father went out in another canoe, to the one in which Shadrach had been fishing, and upon securing the pole, which was floating about, found that Shadrach had hooked an enormous eel, - a fish by no means common in the lake. But Shadrach, regarding it as belonging to the family of snakes, never trusted himself alone after that on the water.

"I've hearn a good deal lately, Squire," said Tucker, after I had finished my story, "about slavery and the Slave States, and I've read some tracts and newspapers, that have been sent around to almost everybody in these parts, on the subject. It seems to 
be a ticklish matter, and makes a good deal of disturbance, and a heap of bad feelins' between the different parts of the country; and I've a notion if there's ever to be trouble between the States, it'll be very likely to grow out of slavery. I'm agin it myself. It's my opinion that the buyin' and sellin' of human men and women, is a thing that ain't accordin' to nater. It don't belong to a free country, and ain't becomin' a free people. A man may talk just as much as he pleases about the blessins' of liberty, and his good will towards the spread of human rights, but if he justifies tradin' in human flesh and blood, and npholds it as a right thing, he ain't a republican in his heart. The liberty he talks about means freedom to himself. His human rights is his own rights, and nobody's else, and I'm agin' him. I won't trust my liberty, nor my rights, nor the rights of my children in his hands, if I can help it, for all his big words and oily talk. But I ain't goin' off on a cruise agin' slavery either. We havn't got any slavery in this State, and I'm glad of it. It's my notion that we came across a great blessin', when it was done away with. It's a great clog on the heels of a country. It keeps it from movin' along and goin' ahead. 
"Labor, Squire, is a great regulator of public morals. I mean free labor,-labor that's paid for,independent labor, that brings a harvest of reward, and that makes a man and his little ones comfortable, and gives 'em a decent education, and a home. There's nothin' in this country that should make a man ashamed to work. Look out over all the free States, and think that two hundred years ago, all that you look upon, all the broad farms, the towns, and the sites of the great cities, were all a wilderness, covered with huge trees. Them great trees had to be chopped down, one at a time. The men who did that work were entitled to some credit,-more, by a long shot, than if they'd mown down armies of men, and plundered their country. Their battle was with the forests, and the victory they won, was over the wilderness. It didn't cost anybody's blood, nor anybody's treasure. The men who did that work had a right to take a dignified and a high place among the people of the airth, and their children needn't be ashamed of their fathers, nor of followin' their example. The world gave them the credit they were entitled to, and it gave dignity to labor, and a good name to the man that worked. It's so still. It's nothing agin' a man, 


\section{Dignity OF Fre Labor. 313}

in this State, to say he's a workin' man. That he airns his bread by the labor of his hands, because tho' he keeps busy all the long day, there's nothin' servile in his labor. He occupies his own place in the world, and is just as independent in his feelins', in his thoughts, and opinions, and just as likely to be rich, and high in office, twenty years hence, as the next man. But in Slave States it ain't so, and can't, accordin' to nater, be so. Free labor can't exist right alongside of slave labor, without robbin' it of its dignity, and makin' it a disgrace. In them States, the work is done by the slaves, and they are a contemned and a despised race. The slave works; and the rich and proud people take up the notion, that every man that works must be looked upon just like a slave, because he works. 'They've a notion that a man who can't or won't own a slave to do his work for him: ain't of much account any how, and they look down upon him, as one lower down on the ladder of respectability than themselves. They make him eat at the second table, and take their own leavin's at that, and that's a thing, Squire, a free American don't often feel inclined to stand. Will anybody tell us, Squire, why Old-Virginia, that was the greatest, the richest, and 


\section{HILLS AND LAKES.}

most pupulous State in the Union, at the close of tho Revolutionary War, has fallen behind a good many other States now? The reason of it can't. be found in her climate, for that, I'm told, is about the finest in the world. It can't be found in the nater of her soil, for I'm told it was once the richest in this country. It isn't because she hasn't any ocean harbors, nor because there ain't any streams or rivers, that come down over precipices and steep places, to make great water- wheels roll round, and set machinery in motion, for people that pretended to know, have told me that there's plenty of all these. The truth is, that slavery and slave labor spiles a people. It makes the master extravagant, and proud, and above work; and there ain't much encouragement for the slave to be smart, when it don't make him any richer or more respectable. It comes over a country like a great blight and a mildew, that takes away the enterprise and the energy of a people, and dries up the go ahead principle, that would otherwise make 'em push along, and keep movin' : and because it does all this, I'm agin' it.

"'Ihen there's the great moral sin of slavery. What right has one man, I should like to know, to buy and sell another man, made by the same God, 


\section{Freedom vis. Slavery.}

fashioned from the same clay, subject to the same nateral laws, governed by the same reason, possessin' the same instincts, and bound to the same eternity at last? I'm a poor man, Squire, and I hold my title to my liberty, as I understand it, not by anything I've done, but because I'm a Mav. I hold it, not on account of what my fathers did, not because they were strong, or rich, or virtuous, or wise, but because God gave me a human form, a face after his own image, and a livin' soul ; and every creeter possessin' them attributes, has just as good a right to his liberty as I have to mine. Strong men may rob mę of it, as they've done to millions and millions of men for thousands of years, and are doin' every day, but that don't -wipe out my right, nor alter the everlastin' fact that I'm entitled, by a charter given to me by God, to be free.

"And then there's another matter I don't like about it. We talk everlastin'ly about our free institooshuns, and use a wonderful deál of big words, especially about election tirnes, and Independence days, about all men bein' by rater equal, and braggin' about our love of freedom, while we've got, right under ous noses, a livin' contradiction of it all. We talk about 
this country bein' the home of the free, and a place for the oppressed of all nations of the airth to find their rights, and their nateral position in, when in one-half of these States, and in the ten miles square where the Congress is held, and which belongs to all the people of the Union, the very worst sort of oppression and wrong is carried on, under the sanction of law, and by the authority of the Constitooshun. Oppression and wrong, that takes away from thinkin' and reflectin' men, and women, every right that pertains to 'em as human creeters, and makes 'em things to be traded on, to be bought and sold like oxen, or bags of wheat, or bales of cotton. It's a great shame, and a burnin' reproach, and I don't wonder that kings and emperors, and great lords, of other countries, turn up their noses at the ${ }^{*}$ idee of our preachin' to them, about knockin' the chains of despotism off the necks of their people.

" But, as I said before, I ain't goin' off on a cruise agin' slavery. May be I don't understand it, as I don't claim to be a wise man, and never was among it. I shan't quarrel with the Slave States about upholdin' it. If they think it a blessin' they've a right to enjoy it, so far as I'm concerned, and I've no right to interfere with 'em in doin' so, and New-York hasn't any right 


\section{The InJustate of Slavery. 317}

to interfere. If it's a sin, they, and not we, are to answer for it. Besides, so long as I see such men as Harry Clay, and Daniel Webster, and General Taylor, takin' care of it, I don't feel very uneasy, and I've come to the conclusion that it won't break up the Union just yet.

"I don't know as it's altogether right, but when I look around, and see the great events that are takin' place in the world, I begin to study into matters, and see if I can trace the designs of Providence, in what He permits to be goin' on upon this airth, and what the end of it all is to be. Now I look upon slavery as the wickedest system, the mightiest sin against God, and man, that the world ever looked upon. And while I say of the Great Ruler of the world, that ' $\mathrm{He}$ ordereth all things well,' and that everything will come out right at last, I ask myself, why is all this great wickedness, this wonderful wrong, permitted to grow up, and spread so? I sometimes think that I have studied out the reason of it all, and found out the great plan that is to be accomplished by it, and, foolish as it may seem in me, I'll tell you what I believe it to be. Africa, as I have been told, and read in books, is a wild and savage county, where the people, not 
"long ago, had no knowledge of the things that belong to civilization; that they were poor, ignorant, heathen idolaters, that had never heard of the Bible, nor anything that belonged to the Christian Religion. That most of the tribes were rovin', and wild barbarians, mòstly at war, killin' and plunderin', and enslavin' each other. I've been told, too, that Africa is away south, and that the sun looks almost straight down upon it, from the beginnin' to the end of the year, and that white people of other countries, become weak, and feeble, and die, under the bad influences of the climate, and that the black man is the only human creeter that's fitted to live, and be healthy and strong, there. Well, I see that them savage people have been brought to this country, and slaves though they be, ignorant and foolish though they be, they become acquainted with human ways, and larn to live like civilized and Christian folks. They grow up with some knowledge of the Bible, and of the Christian Religion, and each generation knows more than the one that went before it. Some of them become free, and are edicated, and, one way and another, pick up a great deal of knowledge. I see away down south, in the British islands, they have all become free, so far as actual slavery is con- 
Good Resulting from Slavery. 319

cerned; and I see it stated in the newspapers, that there is one independent nation of black people, now inhabiting one of the great islands between North and South America. I see, too, that in most of the Southern States, the black people are increasin' faster than the white folks, and it may be, that away off in the future, after hundreds of years shall have passed away, there will be, away down south, a country, embracin', may be, ten Southern States, a great nation of black people, independent of all other nations, makin' their own laws, a Christian and civilized nation, servin' God accordin' to the Bible. And then again, I read of the colored people goin' back to Africa by ship-loads, carryin' with them civilization, and Christianity, and the Bible, and that they are spreadin' out, and growin' amazin'ly, in that country of their fathers. When I see all this, I say to myself that the end of this ' cruel wrong, and great wickedness of slavery, is to build up the colored race, and make them a civilized and Christian people. That slavery, wicked as it surely is, is to be the means of of civilizin' and Chistianizin' Africa. - To save the negro race from bein" clean wiped out, as the Ingens of this country will one day be. To make Africa a 
home for Christian men, and give to a portion of the black people a country and a home, at least, on this side of the great ocean, in a climate fitted for 'em."

"Well," said I, "Tucker, you have studied out, as you say, a plausible theory. But if such were the designs of Providence, could they not have been brought about with less of what you call wickedness and cruel wrong, and in a shorter period than will be required to accomplish it all ?"

"Squire," he replied, "it is not for you and I to sit in judgment upon the dealin's of Providence, in regard to His management of the things $\mathrm{He}$ has made. What to man's wisdom seems to be a mystery beyond findin' out, may one day be made plain, and the things that look crooked now, one day seem all straight and right. I don't undertake to say my notions as to this matter are correct all through, but you and I know that the children of the men that hard-hearted and wicked people stole in Africa, and brought over the ocean, and sold into slavery here, have taken back to that same Africa, civilization, freedom, and the Bible. We know, too, that the generations of the colored people, as they come along, are creepin' up, slowly, in knowledge, and in the ways of white folks; 
and it isn't onlikely that each generation of the future will creep up a little higher, till one day they may attain to the full growth and perfect stature of manhood, and in all that belongs to the most finished work of the Great God.

"As to what you say respectin' the time necessary to bring it all about, I have thought of that, too, and I've read in the Bible what, to my notion, answers it all. Nater, or rather the Great God of nater, ain't bound down to years, or hundreds of years. With Him, ' a single day is as a thousand years, and a thousand years as one day.' Hundreds of generations passin' before Him, are as the lightnin' flashin' from the cloud, before the eyes of a man. It takes the tall pine a hundred years to grow to its full strength, and yet another hundred years to grow weak, and rotten, and fall to the ground. It took this country two hundred years to fit itself for independence and progress, but the causes that were to make it great, and firm, and strong, were all the time at work. So it will take the black people a long while to grow up, and the white people long time to go down, before the great change can come. You and I, Squire, must finish our work in the time allotted to us, We must hurry on 
to its completion, while our day lasts, and our sun of life is in the sky, or we shall be overtaken by the darkness before our task is done. But with the Great Ruler of the Universe, there is no mornin', and no night; there is no yesterday, nor to-morrow. With Him all time is present, -an everlastin' and eternal sow. And whether He puts forth His arm, and hurls things with the rush of the tempest, or leaves them to the silent but sure process of ages, it is all the same. You and I, of course, will not live to see it, nor will any that can trace us out as among their forefathers, see it; but I believe that away off in the long future, may be hundreds and hundreds of years to come, Africa will be made up of great nations of colored people, all civilized and Christianized, havin' great navies and merchant ships visitin' all parts of the world, and factories, and machine shops, and great cities, and broad farms, and abundance of wealth, and worshippin' God accordin' to the Bible. And I believe, too, that some portion of what is now independent States of this Union, and the islands of the Mexican Gulf, will be other independent and free nations of civilized and Christianized colored people ; and all this mighty change will grow out of this great wicked- 


\section{The End of Slavery.}

ness of human slavery. In this way, as I heard a preacher say once, the very wickedness of the people will be made to carry forward the good work of the Great God, and the wrath of man shall be made to praise Him." 


\section{XXXI.}

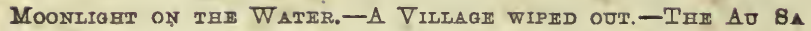
betr.-Kristilite-Thi Gorgh. -An Orit Pit.

This was one of the most beautiful evenings that I had seen since I entered the woods. The moon was at its full, and its brightness was upon everything around us. Mountain and forest, and the still lake, were ali shining in its beams, and the little bays, hidden within the shadows of the tall trees, had just enough of obscure and spectral twilight about them to give them a superstitious and solemn charm. While my guide slept I seated myself in our little craft, and drifted out into the water, for it was too pleasant for sleep.

Nothing can be more delightful than to float on one of these beautiful lakes in a calm, warm night. There is nothing but sweetness in the air, nothing but pleasant sounds falling upon the ear. The loon lifts up his clarion voice, waking the echoes of the moun. 
tains, and his quavering notes die away like the voice of a trumpet in the distance. The owl hoots solemnly in the woods, and the frog croaks along the shore. The air moans among the tall old pines, and the trout splashes the water as he leaps, in his gladness, above the surface. The fire-flies flash their tiny torches, and the stars look up from away down in the quiet waters, and down from the sky above you. If you shout, a thousand voices echo back the sound. If you sing, hundreds of voices prolong the song; while through all the night sounds, silence seems to be struggling for dominion, and you say, while a hundred voices were heard at once, "How still it is !"

The time to which I had limited my tramp in the woods had already expired, and the next morning, while the sun was just showing his great red faco through mist and haze, over the summit of the eastern hills, we bade adieu to these beautiful lakes, the most picturesque and charming in all this broad country, and started for the nearest settlement towards the Champlain. We struck for Franklin Falls, a little hamlet, the one deepest in the forest in that direction, on the Saranac River, eighteen or twenty miles distant. We reached it, weary enough, about thres 
o'clock. We were hungry enough, too, and the dinner-cooked by the landlady, after the way of civilization, the fresh wheat bread and the sweet milk-was a pleasant thing to sit down to.

This pleasant little hamlet has its history, eventful though brief, a part of which has transpired since my guide and myself visited it on this our return from our "tramp in the Chataugay Woods." It was a small place then, and has since been entirely "wiped out." It has; however, appeared again, and it is now, in 1854, a smart, neat little town, remarkable, however, only for one of the finest mills for the manufacture of lumber in the State-a mill capable of sawing forty thousand feet of lumber per day. I have never seen so extensive an establishment for the manufacturing of lumber, about which everything was so neat, and which is managed with such system and order. There are, perhaps, a dozen or more houses clustered together, conspicuous among which is a large tavern house, just being finished. A year ago, this little town was as large as it is now. It contained as many houses, nearly as good a mill, and as many inhabitants. It was squatted down right in the woods-all around it was forest. The trees that had been chop- 


\section{A Town Burnte}

ped down and those that had been blown down lay where they fell, with all that was combustible around them, in a fit condition for burning. A fire in the woods here, under any circumstances, is a terrific thing, but when such additional incentives to its fury as were scattered around this little town exist, it is irresistible. From some cause a fire broke out some half a mile to the southwest of the village. The wind was strong, and the flames rushed forward with the speed of a race-horse and the roar of a tornado. Its career was one of resistless fury. Flashing and swirling, leaping upward and onward, the dense columns of smoke and flame curling and wreathing towards the sky, and borne forward by the winds, soon reached the devoted little town. The power of man was as a reed in its course, and every vestige of the village was swept away. Houses, barns, shops, mills, everything that would burn, was consumed, and where, when the sun rose, was a busy hamlet, when it set, was only smoking desolation. Not a vestige of a human habitation-not a structure reared by the hands of man-was left. The little town in the woods was wiped out, and smouldering ruins, charred chunks, and heaps of ashes, alone marked the spot 
where it stood. The flames, as if rejoicing in their power, swept onward over the hill, to the north, leaving desolation behind them, and paused only when they found no dry thing to consume. Any other man than the owner of the town, would have sunk under the calamity. Some $\$ 50,000$ of his property was destroyed, and, with other embarrassments pressing upon him, the spirit of any other man would have been broken. Not so with $\mathrm{P}-\mathrm{C}-$ With a will that nothing could bend-an energy unconquerable as destiny - he rose up from the misfortune that overwhelmed him, defiant of fate; and scorning the power of the elements, he reared from those ashes of desolation a phœnix-stronger and better than that which destruction had swept away. Where the old mill stood, stands a better one. Hundreds of thousands of feet of lumber are piled along the road, for half a mile, and great stacks of it surround the mill. Thirty teams are drawing from these long rows of piled-up boards, and as one pile disappears, another takes its place. Where the former tavern and store stood, stands another and a better. Each dwellinghouse destroyed, is replaced by a new one, and a few charred fragments, scattered about, are all that remains 
to remind one of the fire that made such a clean sweep of the town. Honor, I say, to all such men as $\mathrm{P}$

$\mathrm{C}$ - They may be unfortunate; they may undertake more than human agency can entirely perform; they may not succeed in amassing a fortune; destiny may be against them; they may work hard and die poor; they may fall; their notes may be protested;but the world owes them a debt of gratitude. It is just such men who push for'ward civilization-who sweep away the forests-who let the sun, with its genial influences, down upon the earth, where tall trees once obstructed his rays-who spread out green fields, and built up towns in the ancient wilderness-who give employment to labor, and impress progress upon everything around them. Bankers may discredit their notes, and usurers prey upon them; but they are the true "manifest destiny men," who give to our - country practical dominion over nature, by pushing civilization into the waste and desolate places in the wilderness. They chain the mad waters to great wheels, and make them grind corn, give shape and fitness for use to great forest trees, extract the metals from the solid rock, and throw the shuttle and spin. 
Honor to all such men as $\mathrm{P}-\mathrm{C} \longrightarrow$, I say-let the world judge them as it may.

We left Franklin Falls the next morning for the valley of the Au Sable, and, arriving at the Forks, my "tramp in the Chataugay Woods" was over. I had left the "hills and lakes" far behind me, the latter sleeping, as I found them, in the quietude of the forests, and among old primeval things. "Au Sable Forks" is twelve miles above Keeseville. It is a little manufacturing town. When I say little, I mean only in respect to the number of houses, for the amount of business done in the shape of iron making, is greatly disproportionate to the outward seeming of the place. There is here one of the largest establishments for the manufacturing of iron and nails on the river. $A$ single firm make some twelve hundred kegs of nails weekly, and in all the departments of their business, employ between five and six hundred men. The great hammers are pounding away continually-some forty nail-making machines are clanking - the great water-wheels are going on their ceaseless rounds-the big bellows are puffing - the forges and furnaces are blazing-and the great rollers are turning out their fiery serpents always, save from twelve o'clock Satur- 
day till twielve o'clock Sunday nights, of each week. Everybody and everything are busy. Teams are busy, men are busy, the waters are busy. Business, activity, energy, go-ahead, are written upon everything.

We hired a conveyance to take us to Keeserille. This is a pleasant, town, on the banks of the Au Sable River. It is a quiet place, away from the thunder of railroads, the roar of the steam-pipe, or the scream of the steam-whistle; but you hear, day and night, other sounds quite as indicative of civilization, quite as suggestive of progress. The blows of the monster triphammer, the ceaseless rumbling of great water-wheels, the puffing of great bellows, and the clank of machinery, are never silent, save on the Sabbath. The world knows but little of the natural wealth of this portion of the State, or the extent of its manufactures. On this little river, within fifteen miles of Keeseville, are made over eight thousand tons of nails alone-not from iron manufactured abroad, but from ore dug from the bowels of the earth here. It will be remembered that this vast amount constitutes but a portion of the iron manufactured here. You will hear the ponderous hammer, as it makes the iron into bars of all 
sizes, and you will see it piled in huge quantities in the store-houses connected with the works, while teams are constantly employed drawing it away to Port Kent, the depôt where it starts on its journey by water to the southern and eastern markets. The manufacturers here dig their own ore, separate and wash it. They burn their own charcoal, and from the ore that is taken from the mines, they go clear through with the manufacture of iron, without the use of a single material that is not produced on the spot, or within the same township. The ore goes in at one end of the works, and comes out in nails or finished bars at the other. The rushing sound of the great bellows, the rumbling of the water-wheel, the thundering blows of the trip-hammer, and the clank, clank, of the nail-making machines, are all mingled on the ear at once.

It was a pleasant thing to see one of these great workshops in the night-time. The glare of the forges, the intense light of the chunks of iron, as they came at a white heat from the blazing furnace; to see them pass through the immense rollers as they were formed into fitness for nail-making, coming out from the pressing machine longer and longer, increasing in 
length, stretching out and running along the floor like gigantic fiery serpents, while the stalwart operatives handled them with iron tongs, as if they were harmless things. I visited one of these works at midnight, and spent an hour among the furnaces and blazing iron, looking upon these strong-armed men as they converted seeming rocks into one of the most useful articles of commerce.

The Gorge, some two miles below Keeseville, is one of the greatest curiosities of this country. The river goes roaring, and plunging: and cascading, more than a mile, through a chasm some thirty feet wide, on either side of which the rocks rise in perpendicular precipices, from one to two hundred feet in height. On the top of these ledges you may stand, on the very verge of these great high walls, and look away down upon the boiling waters, as they go surging and roaring on their way. This chasm does not seem to havebeen worn out by the river, in its everlasting flow, but to have been made by the parting of the hills. The rocks on one side are counterparts of the rocks on the other, as if pulled apart. Rock matches rock, and shape is fitted to shape. An indentation on the one side, is matched by a prominence on the other, and 
you can see plainly that if the river could be with. drawn, and the chasm pressed together, the two sides would fit it like the halves of an apple that had been cleft by the blade of a knife. Above Keeseville are evidences that a lake once covered what is now a beautiful valley, stretching away for miles to the southwest, and through which the $\mathrm{Au}$ Sable now flows. Where now are rich farms, was once the bottom of this lake, and fishes sported above the fields that are now rich meadows, or covered with grain. Some mighty power, centuries upon centuries ago, struggling in the remote depths of the earth, upheaved these hills, tiH the surface parted, leaving this gorge, through which the pent-up waters rushed, emptying the lake of its contents, and giving its foundations to the world as a place for man to beautify, over which the ploughshare should pass, and his flocks and herds feed.

In company with a friend, I went some three miles west of the village, to what is called Halleck Hill, to see one of those quiet landscapes, upon which the eye loves to rest. It was not a rugged mountain scene, where giant ranges stretch away, and tall peaks lift their bald head to the clouds. There was no desola. 
tion, no wild and rocky sterility, but a beautiful level plain, a valley reaching away for miles, rich in agricultural products, and teeming with the evidences of wealth and civilization, Away off to the right was the Champlain. The spires of Plattsburgh could be seen in the distance, seeming to rise like white pillars from the depths of a belt of forest, while in front of them can be viewed the spot where was fought the naval battle of Lake Champlain, in the last war. The beautiful landscape before me was the valley of the little $\mathrm{Au}$ Sable. It was settled by Quakers, men of peace, who till the ground in quiet, and never go up to the wars with weapons of destruction in their hands. The spot was pointed out to me where these peaceful people, startled by the booming cannon, went up and stood, to view the conflict on the lake, when McDonough and Downie fought against each other. These men of peace were patriots. They loved their country, and while from principle they refrained from the shedding of human blood, yet their hearts and their prayers were with their countrymon, against their country's foes. 'Whien the smoke of the battle floated away, and the triumph of American arms was manifest, there went up a shout of gladness, 
a loud hurrah from these honest Quakers, which showed that the old man was strong within them.

In plain view from where I stood is the little island, on which the killed in that memorable battlo were buried. There, in the milst of the lake, side by side, in amity, rest the bones of those who struggled against each other on that day of mortal strife. Death is a queller of animosities, and the hands that struck at each other in life, are quiet enough in the grave. Brave men are sleeping on that little island. It should be regarded as consecrated ground, and a tall monument should be erected to their memory. It should be made to speak of the noble daring of the men who periled and lost their lives for their country. There are no rich men buried here. No titled men. They -were the sailors, men who stood by the great guns, and whose breasts were bared to the foe. They were what the world calls common men, and who, had they survived the battle, would have lived and died without fame; but they are just the men who win victories, and bring fame to commodores and generals, and upon whose bravery hangs the result of the battles. Over the bones of these brave men buried here, - these poor men, these sailors, these "common men," 
should be erected what will save them from desecration, and tell to the far-off generations how stoutly they fought, and how bravely they fell, in the cause of their country.

I went in company with my friend to the Palmer Hill Ore-bed. This hill, which supplies at present most of the forges with ore, rises from a level plain to the height of perhaps two hundred feet, in a round, conical form, having a diameter at the base of from one and a-half to two miles. The main opening to the mines, or rather where the principal vein cropped out, and where it was first worked, is near the top of the hill. The vein pitched downward at an angle of some forty-five degrees, and has been worked a vast distance into the hill. As I approached one of these vast openings, a stream of cold air came up, which in the sultriness of the heat above, was exceedingly refreshing. I stood looking away down into what to me were unknown depths, where the darkness was impenetrable, when a sound came up from the very centre of the hill, louder to my ears than a hundred cannon, and went bellowing, and roaring, and shak. ing the earth, as it reverberated among the drifts and deep excavations of the mines. I started back in af- 
fright, while my friend enjoyed a hearty laugh at my amazement. It was a blast made in a remote part of the mines. We entered the hill by a tunnel of some three hundred, feet in length, by which teams enter to draw out the ore that is raised from the deep foundations of the mines. We found several wagons in the interior of the mountain, being loaded with ore. Above me was a lofty arch, sustained by gigantic stone pillars, and supporting a roof of perhaps a hundred feet of solid rock, through which, at intervals, the light came down through great chimneys, as it were, and through which we could look out upon the clear sky. All around us were openings that stretched away, hundreds and hundreds of feet down, through the gloomy depths of which, the lamps of a hundred miners twinkled like tiny little stars in the darkness. We could hear their hammers, as they drilled into the solid ore, and ever and anon would come the deafening roar of the blasting, shaking the arches by its detonations, and dying away among the caverned depths. A ladder was visible, down which I was invited to descend to where the little lights twinkled. But I declined. I prefer daylight and a firm footing, to a fall or tumble of hundreds of feet among broken 
rocks, and being dashed to pieces in the darkness. While we were in the hill, the hour for dinner was announced. The little lights began at once to move, and in a few minutes, scores of miners began to emerge from the darkness, up the ladders, covered with the black debris of the mines, and looking like an army of Cyclops, fresh from the forges of Vulean. I was glad when my foot was on the surface again; and when I stood on the level plain, with only the sky above me, with no dark caverns into which to stumble, and no arch of rocks to fall upon me, I felt as McGregor did when his "foot was on his native heath." I am reasonably courageous on the earth's surface, where I can see danger, if it exists; where I can either meet it or run from it; but my nerves won't stand darkness; and gloomy caverns and dark holes in the ground are my abhorrence. This mine is exhaustless, and the deeper it is wrought the richer and more abundant does the ore become. There are other beds scattered around over this region, which will supply the iron-mongers forever, but this is the one from which they at present draw their largest supply. At Plattsburgh my guide and I separated, he to go back to his log-house and little clearing. on the 
borders of civilization, and I to my home in the city. His cheerful and contemplative disposition will make him a contented and a happy man. We parted with regret, certainly so far as I am concerned, and were I to judge by the warm and generous grasp of his hand, I should infer there was a little of the same feeling in his own heart, when he said to me, at parting, as I now say to the reader:- "Good-bye, and a smooth trail through life to you." 



\#B 10160

YB 10167 
ilige $=$

39

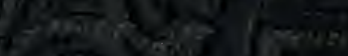

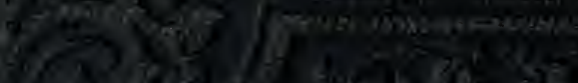

$$
\text { (3) }
$$

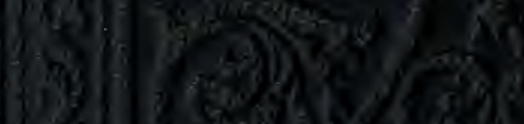

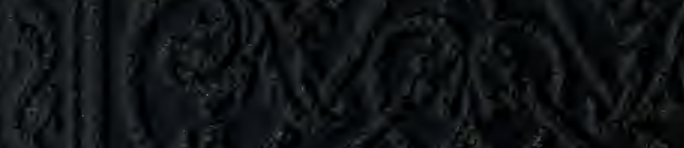

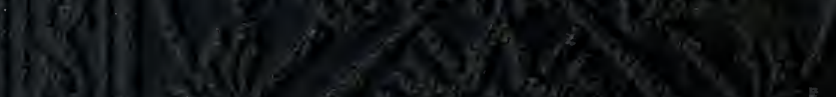

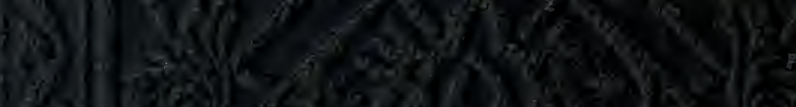

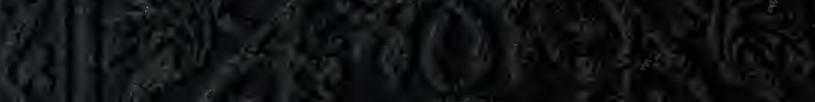

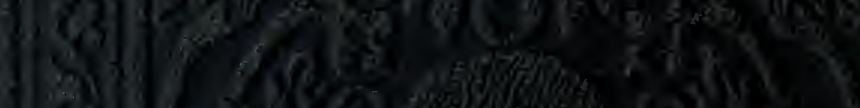

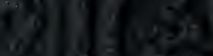

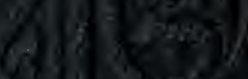

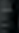
$2 x^{2}$

\section{is}

(ix) (19) 40

2.7

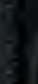

Y.

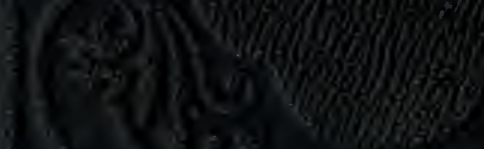

26.

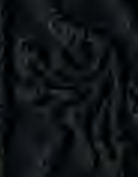

(

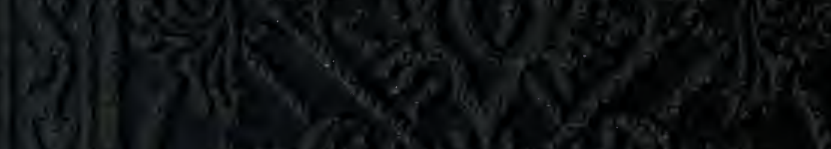

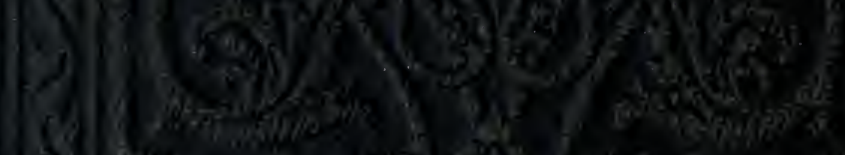

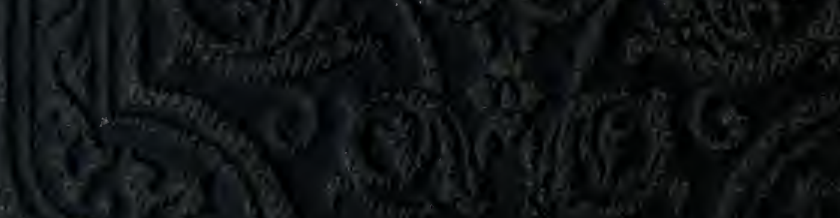
(x)

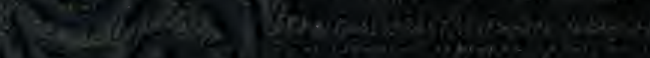

